\title{
Regular treatment with formoterol and inhaled steroids for chronic asthma: serious adverse events (Review)
}

\author{
Cates CJ, Lasserson TJ, Jaeschke R
}

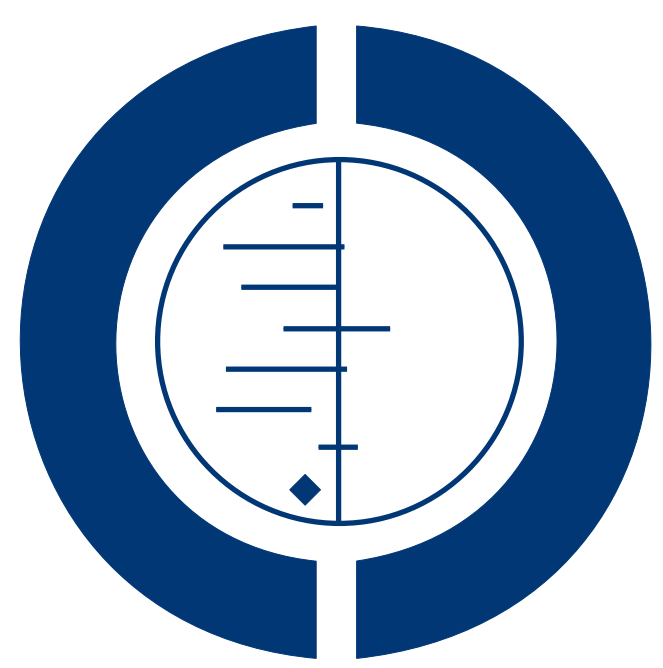

\section{THE COCHRANE COLLABORATION $^{\circledR}$}

This is a reprint of a Cochrane review, prepared and maintained by The Cochrane Collaboration and published in The Cochrane Library 2009, Issue 2

http://www.thecochranelibrary.com

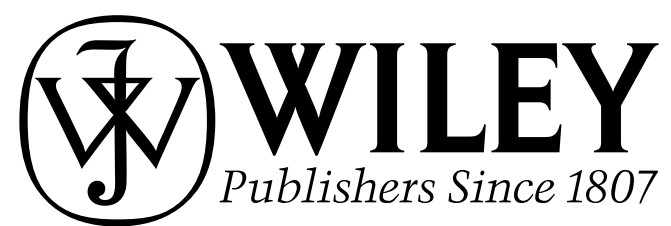

Regular treatment with formoterol and inhaled steroids for chronic asthma: serious adverse events (Review)

Copyright (C) 2009 The Cochrane Collaboration. Published by John Wiley \& Sons, Ltd. 
TABLE OF CONTENTS

HEADER . . . . . . . . . . . . . . . . . . . . . . . . . . . . . . . . 1

ABSTRACT .. . . . . . . . . . . . . . . . . . . . . . . . . . . . . . . . . . . . . . . . . . . . . . . . .

PLAIN LANGUAGE SUMMARY . . . . . . . . . . . . . . . . . . . . . . . . . . . . . . . . . . . $\quad$. 2

BACKGROUND . . . . . . . . . . . . . . . . . . . . . . . . . . . . . . . . . . . . . 2

OBJECTIVES . . . . . . . . . . . . . . . . . . . . . . . . . . . . . . . . . . . . . . 3

METHODS . . . . . . . . . . . . . . . . . . . . . . . . . . . . . . . . . . . . . . 3

RESULTS . . . . . . . . . . . . . . . . . . . . . . . . . . . . . . . . . . . . . . . 5

Figure 1. . . . . . . . . . . . . . . . . . . . . . . . . . . . . . . . . . . . . . 6

Figure $2 . \quad$. . . . . . . . . . . . . . . . . . . . . . . . . . . . . . . . . . . . . 8

Figure 3. . . . . . . . . . . . . . . . . . . . . . . . . . . . . . . . . . . . . . 9

Figure $4 . \quad$. . . . . . . . . . . . . . . . . . . . . . . . . . . . . . . . . . . . . 10

Figure 5. . . . . . . . . . . . . . . . . . . . . . . . . . . . . . . . . . . . . . 11

Figure 6. . . . . . . . . . . . . . . . . . . . . . . . . . . . . . . . . . . . . . 12

Figure $7 . \quad$. . . . . . . . . . . . . . . . . . . . . . . . . . . . . . . . . . . . . 13

Figure 8. . . . . . . . . . . . . . . . . . . . . . . . . . . . . . . . . . . . . . 14

Figure 9. . . . . . . . . . . . . . . . . . . . . . . . . . . . . . . . . . . . . . 15

Figure 10. . . . . . . . . . . . . . . . . . . . . . . . . . . . . . . . . . . . . . 16

Figure 11. . . . . . . . . . . . . . . . . . . . . . . . . . . . . . . . . . . . . . 17

Figure 12. . . . . . . . . . . . . . . . . . . . . . . . . . . . . . . . . . . . . . 18

DISCUSSION . . . . . . . . . . . . . . . . . . . . . . . . . . . . . . . . . . . . . 18

Figure 13. . . . . . . . . . . . . . . . . . . . . . . . . . . . . . . . . . . . . . 20

Figure $14 . \quad$. . . . . . . . . . . . . . . . . . . . . . . . . . . . . . . . . . . . . 21

AUTHORS' CONCLUSIONS . . . . . . . . . . . . . . . . . . . . . . . . . . . . . . . . . . . 21

ACKNOWLEDGEMENTS . . . . . . . . . . . . . . . . . . . . . . . . . . . . . . . . . . . . . . . . $\quad 22$

REFERENCES . . . . . . . . . . . . . . . . . . . . . . . . . . . . . . . . . . . . . . 22

CHARACTERISTICS OF STUDIES . . . . . . . . . . . . . . . . . . . . . . . . . . . . . . . . . . . . . . .

DATA AND ANALYSES . . . . . . . . . . . . . . . . . . . . . . . . . . . . . . . . . . . . . . . . . . . . . . . . 63

Analysis 1.1. Comparison 1 Formoterol and ICS versus same dose ICS, Outcome 1 All-cause Mortality. . . . . . . $\quad 64$

Analysis 1.2. Comparison 1 Formoterol and ICS versus same dose ICS, Outcome 2 All-cause non-fatal Serious Adverse Events.

Analysis 1.3. Comparison 1 Formoterol and ICS versus same dose ICS, Outcome 3 Asthma Mortality.

Analysis 1.4. Comparison 1 Formoterol and ICS versus same dose ICS, Outcome 4 Asthma-related non-fatal Serious Adverse Events. . . . . . . . . . . . . . . . . . . . . . . . . . . . . . . . . . 68

Analysis 1.5. Comparison 1 Formoterol and ICS versus same dose ICS, Outcome 5 All-cause Mortality (risk difference). 70

Analysis 1.6. Comparison 1 Formoterol and ICS versus same dose ICS, Outcome 6 All-cause non-fatal Serious Adverse Events (risk difference).

Analysis 1.7. Comparison 1 Formoterol and ICS versus same dose ICS, Outcome 7 Asthma-related non-fatal Serious Adverse Events (risk difference).

Analysis 1.8. Comparison 1 Formoterol and ICS versus same dose ICS, Outcome 8 All-cause Mortality (Mantel-Haenszel fixed).

Analysis 1.9. Comparison 1 Formoterol and ICS versus same dose ICS, Outcome 9 All-cause non-fatal Serious Adverse Events (Mantel-Haenszel fixed).

Analysis 1.10. Comparison 1 Formoterol and ICS versus same dose ICS, Outcome 10 All-cause non-fatal Serious Adverse

Events (sensitivity analysis without unblinded study). . . . . . . . . . . . . . . . . . . . . 78

ADDITIONAL TABLES . . . . . . . . . . . . . . . . . . . . . . . . . . . . . . . . . . 79

APPENDICES . . . . . . . . . . . . . . . . . . . . . . . . . . . . . . . . . . . . . 81

HISTORY . . . . . . . . . . . . . . . . . . . . . . . . . . . . . . . . . . . . . . . 84

CONTRIBUTIONS OF AUTHORS . . . . . . . . . . . . . . . . . . . . . . . . . . . . . . . . . . . . . . . . 84

DECLARATIONS OF INTEREST . . . . . . . . . . . . . . . . . . . . . . . . . . . . . . . . . . . . . . 85

SOURCES OF SUPPORT . . . . . . . . . . . . . . . . . . . . . . . . . . . . . . . . . . . . . . . . . . . . 85

DIFFERENCES BETWEEN PROTOCOL AND REVIEW

Regular treatment with formoterol and inhaled steroids for chronic asthma: serious adverse events (Review)

Copyright ( 2009 The Cochrane Collaboration. Published by John Wiley \& Sons, Ltd. 
Copyright (@) 2009 The Cochrane Collaboration. Published by John Wiley \& Sons, Ltd. 


\title{
[Intervention Review]
}

\section{Regular treatment with formoterol and inhaled steroids for chronic asthma: serious adverse events}

\author{
Christopher J Cates ${ }^{1}$, Toby J Lasserson ${ }^{1}$, Roman Jaeschke ${ }^{2}$ \\ ${ }^{1}$ Community Health Sciences, St George's, University of London, London, UK. ${ }^{2}$ Department of Medicine, McMaster University , \\ Hamilton, Canada \\ Contact address: Christopher J Cates, Community Health Sciences, St George's, University of London, Cranmer Terrace, London, \\ SW170RE, UK. ccates@sgul.ac.uk .
}

Editorial group: Cochrane Airways Group.

Publication status and date: New, published in Issue 2, 2009.

Review content assessed as up-to-date: 20 November 2008.

Citation: Cates CJ, Lasserson TJ, Jaeschke R. Regular treatment with formoterol and inhaled steroids for chronic asthma: serious adverse events. Cochrane Database of Systematic Reviews 2009, Issue 2. Art. No.: CD006924. DOI: 10.1002/14651858.CD006924.pub2.

Copyright ( 2009 The Cochrane Collaboration. Published by John Wiley \& Sons, Ltd.

\section{A B S T R A C T}

\section{Background}

Epidemiological evidence has suggested a link between beta2-agonists and increases in asthma mortality. There has been much debate about possible causal links for this association, and whether regular (daily) long-acting beta2-agonists are safe when used alone or in conjunction with inhaled corticosteroids.

\section{Objectives}

The aim of this review is to assess the risk of fatal and non-fatal serious adverse events in trials that randomised patients with chronic asthma to regular formoterol with inhaled corticosteroids versus the same dose of inhaled corticosteroids alone.

\section{Search methods}

Trials were identified using the Cochrane Airways Group Specialised Register of trials. Web sites of clinical trial registers were checked for unpublished trial data and Food and Drug Administration (FDA) submissions in relation to formoterol were also checked. The date of the most recent search was October 2008.

\section{Selection criteria}

Controlled parallel design clinical trials on patients of any age and severity of asthma were included if they randomised patients to treatment with regular formoterol and inhaled corticosteroids, and were of at least 12 weeks duration.

\section{Data collection and analysis}

Two authors independently selected trials for inclusion in the review. Outcome data were independently extracted by two authors. Unpublished data on mortality and serious adverse events were obtained from the sponsors.

\section{Main results}

The review included 14 studies on adults and adolescents (8,028 participants) and seven studies on children and adolescents (2,788 participants). Data on all cause fatal and non-fatal serious adverse events were found for all studies, and the overall risk of bias was low.

Four deaths occurred on regular formoterol with inhaled corticosteroids, and none on regular inhaled corticosteroids alone. All the deaths were in adults, and one was reported to be asthma-related. The difference was not statistically significant. 
Non-fatal serious adverse events of any cause were very similar in adults [Peto Odds Ratio 0.99 (95\% CI 0.74 to 1.33)], and an increase in events in children on regular formoterol was not statistically significant [Peto Odds Ratio 1.62 (95\% CI 0.80 to 3.28)].

Asthma related serious adverse events on formoterol were lower in adults [Peto Odds Ratio 0.53 (95\% CI 0.28 to 1.00)] and although they were higher in children [Peto Odds Ratio 1.49 (95\% CI 0.48 to 4.61)], this was not statistically significant.

\section{Authors' conclusions}

It is not possible, from the data in this review, to reassure people with asthma that inhaled corticosteroids with regular formoterol carries no risk of increasing mortality in comparison to inhaled corticosteroids alone as all four deaths occurred among 6,594 people using inhaled corticosteroids with formoterol. On the other hand, we have found no conclusive evidence of harm and there was only one asthma related death registered during over 3,000 patient year observation on formoterol. In adults, the decrease in asthma-related serious adverse events on regular formoterol with inhaled corticosteroids was not accompanied by a decrease in all cause serious adverse events. In children the number of events was too small, and consequently the results too imprecise, to determine whether the increase in all cause non-fatal serious adverse events found in the previous meta-analysis on regular formoterol alone is abolished by the additional use of inhaled corticosteroids. Clinical decisions and information for patients regarding regular use of formoterol have to take into account the balance between known symptomatic benefits of formoterol and the degree of uncertainty and concern associated with its potential harmful effects.

\section{PLAIN LANGUAGE SUMMARY}

\section{Serious adverse events with regular formoterol and inhaled corticosteroids}

There has been some concern raised at the possibility of increased serious adverse events following administration of formoterol, a long-acting beta-agonist, to people with asthma. We analysed data from 14 studies in adults and seven in children. Too few deaths occurred in the trials to gain any conclusive reassurance that regular formoterol taken with inhaled corticosteroids either reduces the risk of mortality, or in fact does not increase it (all four deaths that did occur, including one related to asthma, were among 6,594 patients taking formoterol with inhaled corticosteroids). Serious adverse events were very similar in adults with and without formoterol. Although there were more events on formoterol in children, the difference was not big enough to rule out this as being a chance finding. Similarly, decreased risk of asthma-related serious adverse events in adults and increased risk among children taking formoterol could be also be chance findings.

\section{B A C K G R U N D}

When patients with asthma are not controlled by low dose inhaled corticosteroids alone, many asthma guidelines recommend additional long-acting beta 2 -agonists. Several Cochrane reviews have addressed the efficacy of long-acting beta2-agonists in addition to inhaled corticosteroids (Ni Chroinin 2004; Ni Chroinin 2005), in comparison with placebo (Walters 2007), short-acting beta 2 -agonists(Walters 2002), leukotriene-receptor antagonists (Ducharme 2006) and assessed them against increased doses of inhaled corticosteroids (Greenstone 2005). The beneficial effects of long-acting beta 2 -agonists on lung function, symptoms, quality of life and exacerbations requiring oral steroids have been demonstrated.

However, there is also longstanding controversy over the regular use of beta 2 -agonists in asthma. Sears 1986 suggested that excessive use of short acting beta 2 -agonists might have contributed di- rectly or indirectly to increases in asthma deaths in New Zealand between 1960 and 1980. The authors comment that "most deaths were associated with poor assessment, underestimation of severity and inappropriate treatment (over-reliance on bronchodilators and under use of systemic corticosteroids), and delays in obtaining help."

Concern remains that the symptomatic benefit from treatment with long-acting beta 2 -agonists might lead to underestimation of attack severity in acute asthma, and could lead to an increase in asthma-related deaths. Furthermore, regular treatment with beta2agonists can lead to tolerance to their bronchodilator effects and this phenomenon may be more marked with longer acting as opposed to shorter acting compounds (Lipworth 1997). A number of molecular mechanisms have been proposed to explain the possi- 
ble detrimental effect of long-term beta 2 -agonist use in asthma including receptor down regulation and desensitisation (Giembycz 2006).

There are two currently available long-acting beta 2 -agonists, salmeterol and formoterol (also known as eformoterol). These two drugs are known to have differences in speed of onset and receptor activity, and are used in different ways (for example salmeterol has a slower onset of action than salbutamol Beach 1992 and is therefore unsuitable for use as a reliever). 'The Fenoterol Story' is a reminder that all beta 2 -agonists may not carry the same risks (Pearce 2007), so in view of the potential difference in adverse effects between salmeterol and formoterol, we have considered the two drugs separately. Two recent systematic reviews have addressed the impact of long-acting beta 2 -agonists on all cause mortality and serious adverse events: Cates 2008 (salmeterol) and Cates 2008a (formoterol). Both reviews considered long-acting beta $_{2}$-agonists which were randomised without additional inhaled corticosteroids and demonstrated increased risks of non-fatal serious adverse events.

There has been much debate about the interaction between inhaled corticosteroids and long-acting beta2-agonists, in relation to serious adverse events, since the publication of SMART 2006. This study did not randomise patients to inhaled corticosteroids, but nevertheless a subgroup analysis of the results was carried out on the basis of inhaled corticosteroid use at baseline. It is tempting to find reassurance from the fact that there was not a statistically significant increase in asthma-related mortality in the subgroup using inhaled corticosteroids, but this is not the correct way to test for interaction (Altman 2003), and no assessment was carried out during the trial in relation to the actual use of inhaled corticosteroids during the course of the study.

Counfounding by severity has been shown by Sears 2008 in data from the RELIEF study, where the rate of asthma-related SAEs was significantly higher in both arms of the study in patients taking ICS in comparison to those not taking ICS. This is a serious threat to any conclusions drawn from observational data when assessing the interaction between ICS and formoterol. Therefore, there is a need to systematically review all the available data from controlled trials that randomised patients to regular formoterol in combination with inhaled corticosteroids, and to consider all serious adverse events (fatal and non-fatal), whether or not these are deemed by the investigators to be related to trial medication.

The focus of this review is therefore on regular formoterol randomised in combination with inhaled corticosteroids, (in a single inhaler or separate inhalers) and compared to inhaled corticosteroids alone. Due to the difficulty in deciding whether adverse events are asthma-related, this review will focus on studies that capture mortality and serious adverse events, and record both all cause outcomes, and those considered by the trial investigators to be asthma-related events.
A review comparing regular salmeterol randomised in combination with inhaled corticosteroids, (in a single inhaler or separate inhalers) and compared to inhaled corticosteroids alone is also currently ongoing.

\section{O B J E C T IVES}

To assess the risk of mortality and non-fatal serious adverse events in trials which randomise patients with chronic asthma to regular formoterol and inhaled corticosteroid in comparison with the same dose of inhaled corticosteroid.

\section{METHODS}

\section{Criteria for considering studies for this review}

\section{Types of studies}

Controlled parallel design clinical trials, with or without blinding, in which formoterol and inhaled corticosteroid were randomly assigned to patients with chronic asthma in comparison to the same dose of inhaled corticosteroid alone. Studies on acute asthma and exercise induced bronchospasm have not been included.

\section{Types of participants}

Patients with a clinical diagnosis of asthma of any age group, unrestricted by disease severity, previous or current treatment.

\section{Types of interventions}

Inhaled corticosteroids and formoterol given regularly once or twice daily for a period of at least 12 weeks, at any dose and delivered by any single or separate devices (CFC-MDI, HFA-MDI, DPI). Studies that randomised patients to formoterol and inhaled corticosteroids for intermittent use as a reliever have not been included in this review, and studies that compared different doses of formoterol, or different delivery devices or propellants without a placebo arm were also not be included. Studies in which formoterol was randomised without an inhaled steroid have been considered in a separate review (Cates 2008a). Studies that use comparison groups with the same dose and type of inhaled corticosteroids in the control arm will be included in this review, and co-intervention with leukotriene receptor antagonists, cromones or theophylline will be allowed as long as they are not part of the randomised intervention, and are therefore not systematically different between groups. Studies comparing formoterol to salmeterol will be subject to another review and were not included in this review. We have also excluded in this review studies in which 
inhaled corticosteroids were used in all patients as background treatment (rather than randomised intervention).

\section{Types of outcome measures}

\section{Primary outcomes}

1. All cause mortality

2. All cause non-fatal serious adverse events

\section{Secondary outcomes}

1. Asthma-related mortality

2. Asthma-related non-fatal serious adverse events

3. Respiratory-related mortality

4. Respiratory-related non-fatal serious adverse events

5. Cardiovascular-related mortality

6. Cardiovascular-related non-fatal serious adverse events

7. Asthma-related non-fatal life-threatening events (intubation or admission to intensive care)

8. Respiratory-related non-fatal life-threatening events (intubation or admission to intensive care)

Outcomes will not be sub-divided according to whether the trial investigators considered them to be related to trial medication.

\section{Search methods for identification of studies}

\section{Electronic searches}

Trials were identified using the Cochrane Airways Group Specialised Register of trials, which is derived from systematic searches of bibliographic databases including the Cochrane Central Register of Controlled Trials (CENTRAL), MEDLINE, EMBASE, CINAHL, AMED, and PsycINFO, and hand searching of respiratory journals and meeting abstracts. All records in the Specialised Register coded as 'asthma' will be searched using the following terms:

((beta* and agonist*) and (long-acting or "long acting")) or ((beta* and adrenergic*) and (long-acting or "long acting")) or (bronchodilat* and (long-acting or "long acting")) or (salmeterol or formoterol or eformoterol or advair or symbicort or serevent or seretide or oxis)) AND (serious or safety or surveillance or mortality or death or intubat* or adverse or toxicity or complications or tolerability)

\section{Searching other resources}

Reference lists of all primary studies and review articles were checked for additional references. Web sites of clinical trial registers were checked for unpublished trial data and FDA submissions in relation to formoterol were also checked.

\section{Data collection and analysis}

\section{Selection of studies}

Two review authors independently assessed studies identified in the literature searches by examining titles, abstract and keywords fields. Studies that potentially fulfilled the inclusion criteria were obtained in full text. These were independently assessed by CJC and TL for inclusion. Disagreements were resolved by consensus.

\section{Data extraction and management}

Data were extracted using a prepared checklist before being entered into Rev Man 5.0 by one reviewer (CJC), and data extraction and entry were checked by a second reviewer (TL). Outcome data were independently extracted by the third reviewer (RJ) and discrepancies resolved by correspondence with the sponsors. Data included characteristics of included studies (methods, participants, interventions, outcomes) and results of the included studies. Sponsors of included studies were contacted for unpublished adverse event data, and the sponsors's web site was searched for further details of adverse events. All cause serious adverse events (fatal and non-fatal) were recorded, and in view of the difficulty in deciding whether events are asthma related, details of the cause of death and serious adverse events were noted where they are available. The definition of serious adverse events was recorded, and further information was sought if this was not clear (particularly in relation to hospital admissions and serious adverse events).

\section{Assessment of risk of bias in included studies}

One review author (CJC) assessed the included studies for bias protection (including sequence generation for randomisation, allocation concealment, blinding of participants and assessors, loss to follow-up, completeness of outcome assessment and other possible bias prevention), with assistance from Susan Hansen.

\section{Unit of analysis issues}

We confined our analysis to patients with one or more serious adverse events, rather than the number of events that occurred (as the latter are not independent when one patient suffers multiple events).

\section{Assessment of heterogeneity}

Heterogeneity was assessed using $\mathrm{I}^{2}$ to indicate how much of the total heterogeneity found was between, rather than within studies. 


\section{Data synthesis}

The outcomes of this review were dichotomous, and we recorded the number of participants with at least one outcome event by allocated treated group. Pooled Odds Ratio (OR) and Risk Difference (RD) were calculated. The Peto Odds Ratio has advantages when events are rare, as no adjustment for zero cells is required. This property was more important than potential problems with unbalanced treatment arms and large effect sizes in view of the high proportion of zero cells, and therefore the results for serious adverse events were calculated in RevMan 5.0 using the Peto method with the Mantel-Haenszel method for sensitivity analysis. Funnel plots were inspected to assess publication bias.

\section{Subgroup analysis and investigation of heterogeneity}

Subgroup analyses were conducted on the basis of age (adults versus children), and dose of formoterol (usual dose versus high dose). Subgroups were compared using tests for interaction (Altman 2003).

\section{Sensitivity analysis}

Sensitivity analysis was carried out to assess the impact of the method used to combine the study events (Risk Difference, Peto Odds Ratio, and Mantel-Haenszel Odds Ratio). The degree of bias protection in the study designs was also part of sensitivity analysis.

\section{R E S U L T S}

\section{Description of studies}

See: Characteristics of included studies; Characteristics of excluded studies.

\section{Results of the search}

523 abstracts were found from the search of the Cochrane Airways Group Specialised Register of trials in October 2008. For this review 59 abstracts were identified as potentially relevant, and of these 48 were subsequently excluded (see Characteristics of excluded studies) and eleven were included in the review. Ten further trials were identified primarily from the AstraZeneca register of controlled trials (Buhl 2003;D5896C00001;Morice 2007; Morice 2008; Peters 2008; SD-039-0714; SD-039-0718; SD-039-0719; SD-039-0725; SD-039-0726). No additional trials were found from the Novartis web site or the FDA web site. A submission from Novartis to the FDA in December 2008 also indicated that there were not trials in the Novartis database in which patients in randomised trials of Foradil had also been randomised to inhaled corticosteroids (Novartis 2008).

\section{Included studies}

The 21 trials included in this review are described in detail in Characteristics of included studies. There is also a summary of the daily dose of budesonide and formoterol that was used in each trial in Table 1. To avoid confusion, all delivered doses have been converted to an equivalent metered dose (so Symbicort 320/ $9 \mathrm{mcg}$ is a delivered dose that is equivalent to a metered dose of budesonide $400 \mathrm{mcg}$ and formoterol $12 \mathrm{mcg}$ ).

Table 1 also indicates whether each study randomised patients to once or twice daily formoterol, used combined or separate inhalers and delivered the medication using dry powder inhaler (DPI) or pressurised metered-dose inhalers (pMDI). Some trials had more than two arms so featured more than one option in each of these cases. Since OPTIMA (O'Byrne 2001; O’Byrne 2001a) and FACET (Pauwels 1997; Pauwels 1997a) randomised patients into higher and lower doses of budesonide, each has been considered as two separate comparisons and been given two identifiers. The review therefore lists a total of 23 studies, drawn from the 21 trials which have been conducted.

All the trials have been sponsored or supported by AstraZeneca.

\section{Adults}

A total of 8,028 adults and adolescents were randomised in seven trials enrolling participants over the age of 12 years (Corren 2007; Jenkins 2006; Morice 2007; Noonan 2006; D5896C00001; Peters 2008; Price 2002), a further six trials that enrolled adults over the age of 18 years (Buhl 2003; Chuchalin 2002; Kuna 2006; O’Byrne 2001; Pauwels 1997; Zetterstrom 2001) and a single trial enrolling those over 16 years old (SD-039-0726). All these studies had a mean age of greater than 18 years.

The weighted mean duration of the adult and adolescent studies was 31 weeks. The daily metered dose of formoterol used was 12 to $24 \mathrm{mcg}$, with the exception of Jenkins 2006 and Peters 2008 where $48 \mathrm{mcg}$ daily was used (which remains within the licensed daily dose range). The daily metered dose of budesonide ranged from 200 to $1600 \mathrm{mcg}$ (see Table 1).

\section{Children}

The seven trials in children include 2788 participants in the following age ranges: Morice 2008 (6-11 years old), Pohunek 2006 (411), SD-039-0714 (11-17), SD-039-0718 (6-15), SD-039-0719 (6-11), SD-039-0725 (6-15), Tal 2002 (4-17). All these studies had a mean age of participants of less than 18 years.

The weighted mean duration of the children and adolescent studies was 13 weeks. The daily metered dose of formoterol was 12 to 24 mcg. The daily metered dose of budesonide was 200 to $400 \mathrm{mcg}$ (see Table 1). 


\section{Risk of bias in included studies}

An overview of the risk of bias in individual studies is shown in Figure 1.

Figure I. Methodological quality summary: review authors' judgements about each methodological quality item for each included study.

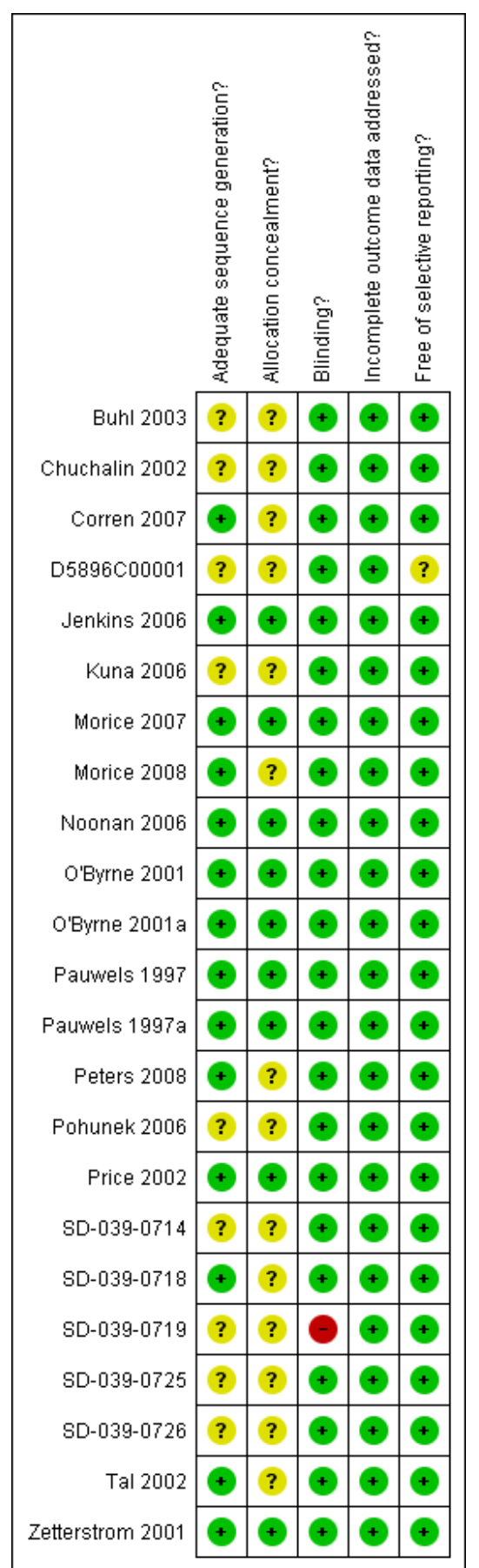




\section{Allocation}

Very little information is available from the paper publications or web reports on sequence generation or allocation concealment, but this is unlikely to be a source of bias in view of the fact that all the studies are sponsored, and standard methodology is likely to have been used to minimise the risk of selection bias.

\section{Blinding}

All of the studies were double-blind with the exception of SD039-0719, which was an open study.

\section{Incomplete outcome data}

The rate of withdrawals and dropouts was clearly reported and was generally less than $20 \%$ of randomised participants, and similarly in the arms of each study.

\section{Selective reporting}

Data have been found or provided from the sponsor for fatal and non-fatal serious adverse events by treatment group and causation for all studies except D5896C00001, which is yet to be published in full and does not include details of asthma-related serious adverse events. With this exception we have therefore obtained data from all trials in relation to the primary outcomes of all cause mortality and all cause serious adverse events.

\section{Other potential sources of bias}

All studies were sponsored or supported by AstraZeneca, the manufacturer of combined budesonide/formoterol inhalers.

\section{Effects of interventions}

\section{Primary Outcomes}

\section{All cause mortality}

There were no deaths in the trials on children and adolescents (2,788 participants). In the adult and adolescent studies $(8,028$ participants), there were four deaths which were all in patients taking formoterol with inhaled corticosteroids. These trials were combined using Peto Odds Ratio (as no continuity correction for zero cells is required). The pooled Peto Odds Ratio was 5.83 (95\% confidence interval 0.78 to 43.77 ) and $\mathrm{I}^{2}$ was zero Figure 2. When analysed using risk differences with a fixed effects model the $\mathrm{RD}$ is 0.001 (95\% CI -0.001 to 0.003$)$ for adults and adolescents and the RD is zero ( $95 \% \mathrm{CI}-0.004$ to 0.004$)$ in trials on children and adolescents (in which there were no deaths) Figure 3. 
Figure 2. Forest plot of comparison: I Formoterol and ICS versus same dose ICS, outcome: I.I All-cause Mortality.

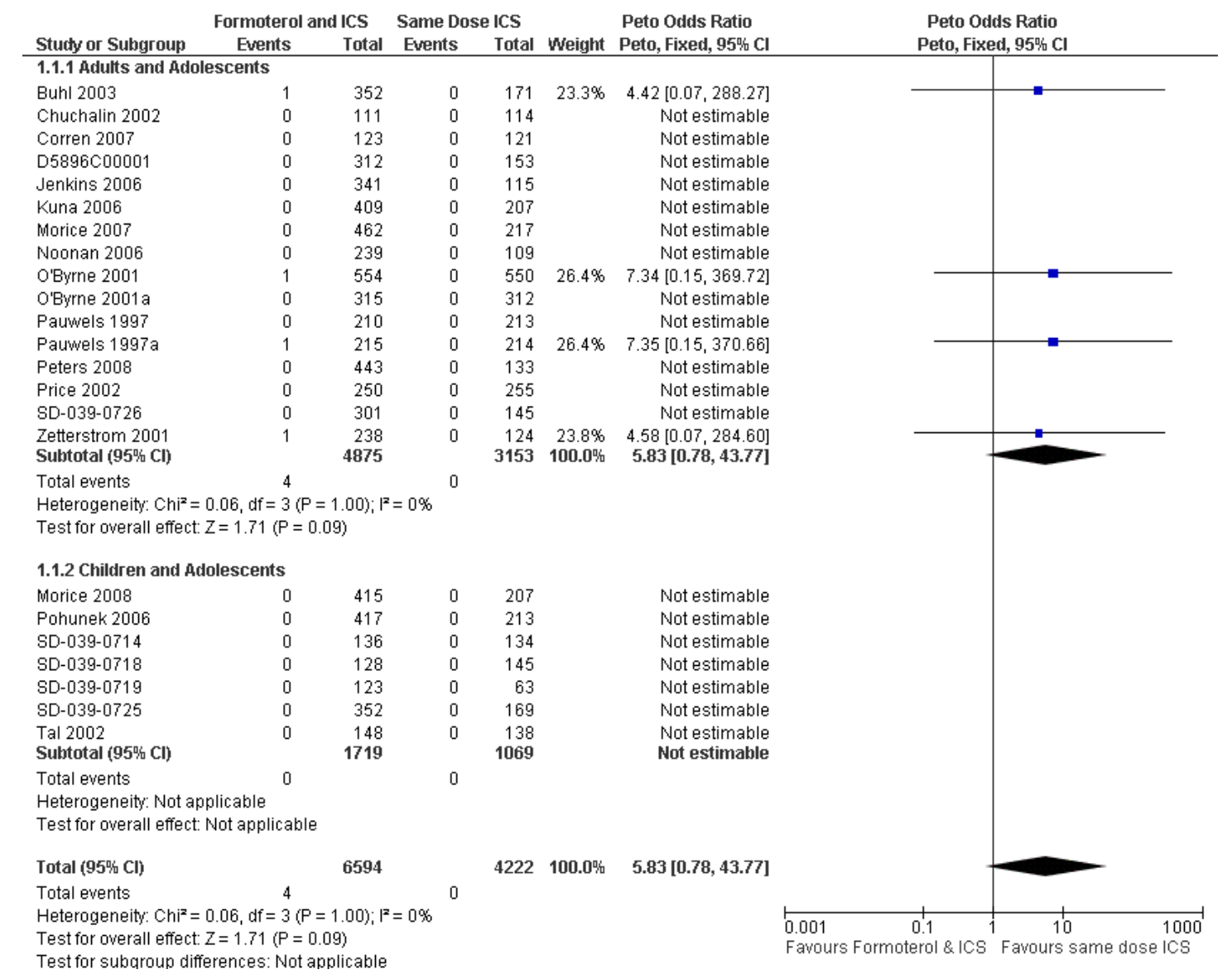


Figure 3. Forest plot of comparison: I Formoterol and ICS versus same dose ICS, outcome: I.5 All-cause Mortality (risk difference)).

\begin{tabular}{|c|c|c|c|c|c|c|c|c|}
\hline Study or Subgroup & \multicolumn{2}{|c|}{ Formoterol and ICS } & \multicolumn{2}{|c|}{ Same Dose ICS } & Weight & $\begin{array}{l}\text { Risk Difference } \\
\text { M-H, Fixed, 95\% } \mathrm{Cl}\end{array}$ & $\begin{array}{l}\text { Risk Difference } \\
\text { M-H, Fixed, 95\% CI }\end{array}$ & \\
\hline \multicolumn{9}{|c|}{ 1.5.1 Adults and Adolescents } \\
\hline Buhl 2003 & 1 & 352 & 0 & 171 & $4.6 \%$ & $0.00[-0.01,0.01]$ & & \\
\hline Chuchalin 2002 & 0 & 111 & 0 & 114 & $2.3 \%$ & $0.00[-0.02,0.02]$ & $\longleftarrow$ & \\
\hline Corren 2007 & 0 & 123 & 0 & 121 & $2.5 \%$ & $0.00[-0.02,0.02]$ & $\longleftarrow$ & \\
\hline D5896C00001 & 0 & 312 & 0 & 153 & $4.1 \%$ & $0.00[-0.01,0.01]$ & & \\
\hline Jenkins 2006 & 0 & 341 & 0 & 115 & $3.5 \%$ & $0.00[-0.01,0.01]$ & & \\
\hline Kuna 2006 & 0 & 409 & 0 & 207 & $5.5 \%$ & $0.00[-0.01,0.01]$ & & \\
\hline Morice 2007 & 0 & 462 & 0 & 217 & $6.0 \%$ & $0.00[-0.01,0.01]$ & & \\
\hline Noonan 2006 & 0 & 239 & 0 & 109 & $3.0 \%$ & $0.00[-0.01,0.01]$ & & \\
\hline O'Byrne 2001 & 1 & 554 & 0 & 550 & $11.1 \%$ & $0.00[-0.00,0.01]$ & & \\
\hline O'Byrne 2001a & 0 & 315 & 0 & 312 & $6.3 \%$ & $0.00[-0.01,0.01]$ & & \\
\hline Pauwels 1997 & 0 & 210 & 0 & 213 & $4.3 \%$ & $0.00[-0.01,0.01]$ & & \\
\hline Pauwels 1997a & 1 & 215 & 0 & 214 & $4.3 \%$ & $0.00[-0.01,0.02]$ & & \\
\hline Peters 2008 & 0 & 443 & 0 & 133 & $4.1 \%$ & $0.00[-0.01,0.01]$ & & \\
\hline Price 2002 & 0 & 250 & 0 & 255 & $5.1 \%$ & $0.00[-0.01,0.01]$ & & \\
\hline SD-039-0726 & 0 & 301 & 0 & 145 & $4.0 \%$ & $0.00[-0.01,0.01]$ & & \\
\hline Zetterstrom 2001 & 1 & 238 & 0 & 124 & $3.3 \%$ & $0.00[-0.01,0.02]$ & & \\
\hline Subtotal (95\% Cl) & & 4875 & & 3153 & $74.1 \%$ & $0.00[-0.00,0.00]$ & & \\
\hline Total events & 4 & & 0 & & & & & \\
\hline \multirow{2}{*}{\multicolumn{9}{|c|}{$\begin{array}{l}\text { Heterogeneity: } \mathrm{Chi}^{2}=1.21, \mathrm{df}=15(\mathrm{P}=1.00) ; \mathrm{I}^{2}=0 \% \\
\text { Test for overall effect: } Z=0.74(P=0.46)\end{array}$}} \\
\hline & & & & & & & & \\
\hline \multicolumn{9}{|c|}{ 1.5.2 Children and Adolescents } \\
\hline Morice 2008 & 0 & 415 & 0 & 207 & $5.6 \%$ & $0.00[-0.01,0.01]$ & & \\
\hline Pohunek 2006 & 0 & 417 & 0 & 213 & $5.7 \%$ & $0.00[-0.01,0.01]$ & & \\
\hline SD-039-0714 & 0 & 136 & 0 & 134 & $2.7 \%$ & $0.00[-0.01,0.01]$ & & \\
\hline SD-039-0718 & 0 & 128 & 0 & 145 & $2.7 \%$ & $0.00[-0.01,0.01]$ & & \\
\hline SD-039-0719 & 0 & 123 & 0 & 63 & $1.7 \%$ & $0.00[-0.02,0.02]$ & & \\
\hline SD-039-0725 & 0 & 352 & 0 & 169 & $4.6 \%$ & $0.00[-0.01,0.01]$ & & \\
\hline Tal 2002 & 0 & 148 & 0 & 138 & $2.9 \%$ & $0.00[-0.01,0.01]$ & $\leftarrow$ & \\
\hline Subtotal (95\% Cl) & & 1719 & & 1069 & $25.9 \%$ & $0.00[-0.00,0.00]$ & & \\
\hline Total events & 0 & & 0 & & & & & \\
\hline \multirow{2}{*}{\multicolumn{9}{|c|}{$\begin{array}{l}\text { Heterogeneity: } \mathrm{Ch}^{2}=0.00, \mathrm{df}=6(\mathrm{P}=1.00) ; \mathrm{I}^{2}=0 \% \\
\text { Test for overall effect: } Z=0.00(P=1.00)\end{array}$}} \\
\hline & & & & & & & & \\
\hline Total $(95 \% \mathrm{Cl})$ & & 6594 & & 4222 & $100.0 \%$ & $0.00[-0.00,0.00]$ & & \\
\hline Total events & 4 & & 0 & & & & & \\
\hline \multicolumn{7}{|c|}{ Heterogeneity: $\mathrm{Ch}^{2}=1.30, \mathrm{df}=22(\mathrm{P}=1.00) ; \mathrm{I}^{2}=0 \%$} & $-0.01 \quad-0.005$ & $0.005 \quad 0.01$ \\
\hline Test for overall effec & $\mathrm{Z}=0.63(\mathrm{P}=$ & & & & & & $\begin{array}{l}-0.01 \\
\text { Favours Formoterol \& ICS Favours }\end{array}$ & $\begin{array}{l}0.005 \\
\text { same dose ICS }\end{array}$ \\
\hline
\end{tabular}

The reports of the deaths included one due to cardiac arrest on combined formoterol and budesonide inhaler treatment (Buhl 2003), one due to status asthmaticus with subsequent development of septic shock on separate formoterol and budesonide inhalers (O'Byrne 2001), one due to suicide on separate formoterol and budesonide inhalers (Pauwels 1997a) and one due to suicide on combined formoterol and budesonide inhaler (Zetterstrom 2001). There was one additional death due to pulmonary embolus on combined treatment in Jenkins 2006, but this death occurred after the budesonide only control arm was discontinued and all patients were receiving formoterol, so it has not been included in the meta-analysis.

\section{Serious Adverse Events (non-fatal all cause)}

A serious adverse event is defined as an event that falls in any of the following categories:
- Results in death,

- Is life-threatening,

- Requires inpatient hospitalization or prolongation of existing hospitalization,

- Results in persistent or significant disability/incapacity, or

- Is a congenital anomaly/birth defect.

This is further explained in Appendix 3, and the sponsors have confirmed that this definition was used in the included trials (even though this was often not made explicit in the paper reports).

\section{All ages}

The combined result in all ages was Peto Odds Ratio of 1.06 (95\% CI 0.81 to 1.39 ) and $\mathrm{I}^{2}$ was $8 \%$ (see Figure 4 ), and the pooled $\mathrm{RD}$ for all ages was 0.001 (95\% CI -0.004 to 0.007$)$ Figure 5. 
Figure 4. Forest plot of comparison: I Formoterol and ICS versus same dose ICS, outcome: I.2 All-cause non-fatal Serious Adverse Events.

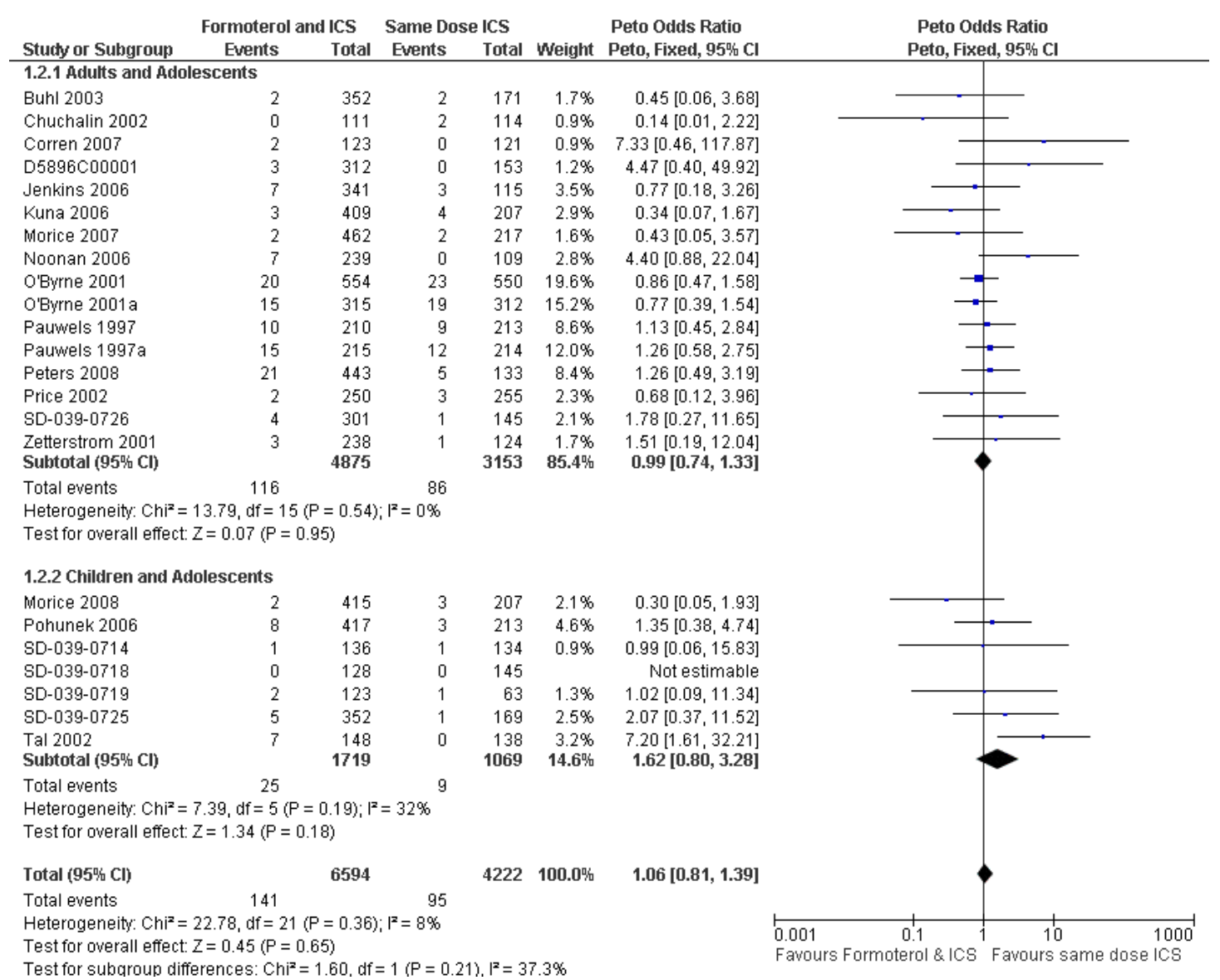


Figure 5. Forest plot of comparison: I Formoterol and ICS versus same dose ICS, outcome: I.6 All-cause non-fatal Serious Adverse Events (risk difference)).

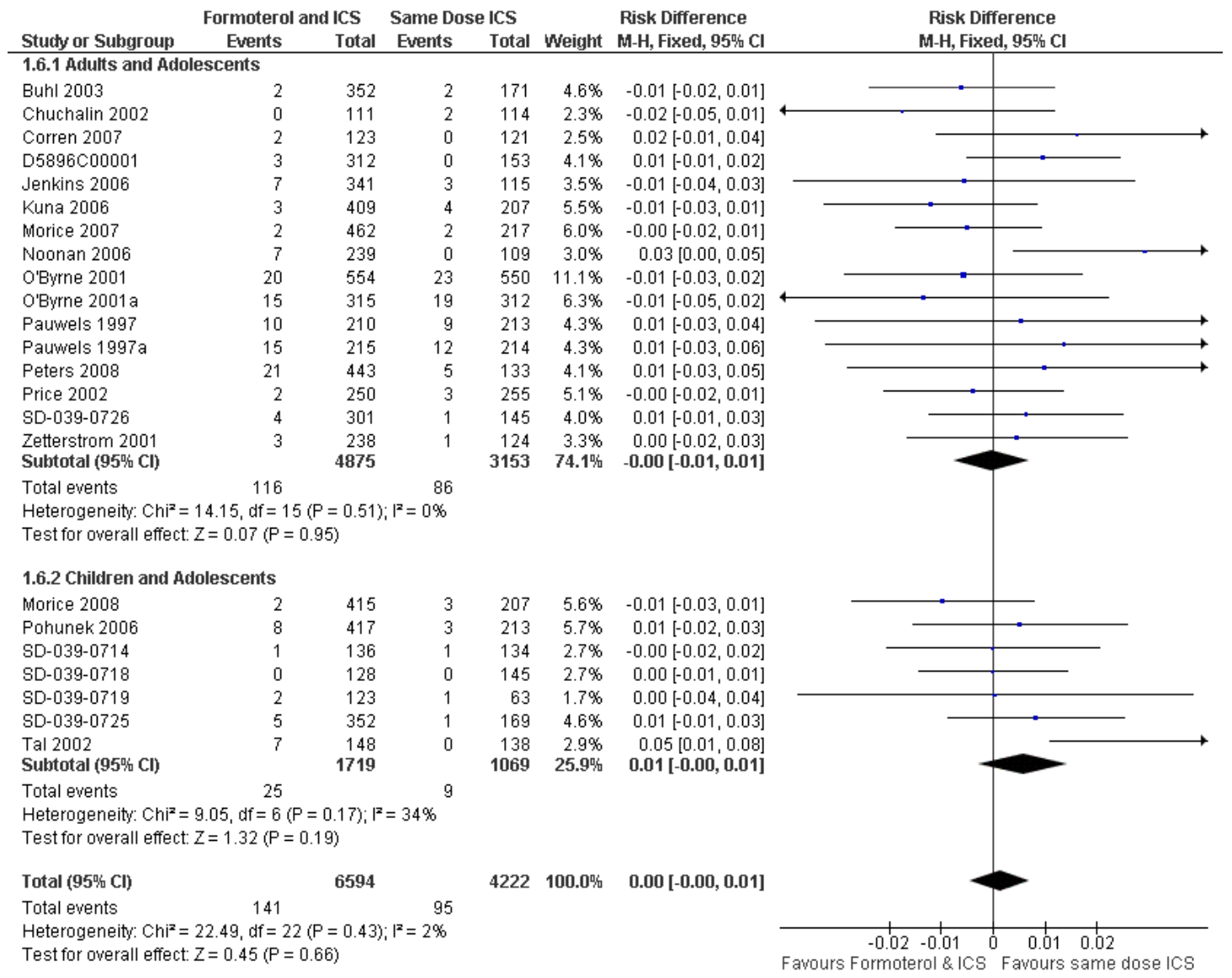

\section{Adults and Adolescents}

The number of patients experiencing one or more non-fatal serious adverse events was very similar when formoterol was randomised with inhaled corticosteroids in comparison to inhaled corticosteroids alone. There were 116 out of 4875 (2.4\%) participants on regular formoterol with ICS and 86 out of $3153(2.7 \%)$ on ICS alone in whom such events occurred. The Peto Odds Ratio was 0.99 ( $95 \%$ CI 0.74 to 1.33 ) and $\mathrm{I}^{2}$ was zero. The pooled $\mathrm{RD}$ was -0.0003 (95\% CI -0.007 to 0.007 ).

\section{Children and Adolescents}

In the trials in patients who were less than 18 years of age the results were more heterogeneous and more non-fatal serious adverse events occurred with formoterol. There were 25 such events amongst young people out of $1719(1.5 \%)$ on regular formoterol with ICS and nine out of $1069(0.8 \%)$ on ICS alone. The Peto
Odds Ratio was 1.62 (95\% CI 0.80 to 3.28$)$ and $\mathrm{I}^{2}$ was $32 \%$, and the pooled RD for children was 0.006 ( $95 \%$ CI -0.003 to 0.01 ). When Tal 2002 is removed from the analysis, the $\mathrm{I}^{2}$ measurement is reduced to 0 . In this study there were seven children with events on formoterol and none on ICS alone.

The test for interaction between adults and children did not find a significant impact of age on the treatment effect.

\section{Secondary Outcomes}

\section{Mortality by cause of death}

None of the four deaths in adults were reported as being due to asthma in the original trial reports, but the death in O'Byrne 2001 (OPTIMA) was subsequently attributed to status asthmaticus and septic shock in a recent meta-analysis (Sears 2008). The full report 
of the cause of death from the sponsors was "One of the deaths occurred in a 35 year old female after an 8 day hospitalization for a severe asthma attack leading to intubation, ventilation, and nosocomial pneumonia with septic shock." This is the only death that has been reported as relating to asthma and was in a patient taking budesonide/formoterol Figure 6 . Two deaths were reported as due to suicide and one as related to cardiac arrest.

Figure 6. Forest plot of comparison: I Formoterol and ICS versus same dose ICS, outcome: I.3 Asthma Mortality.

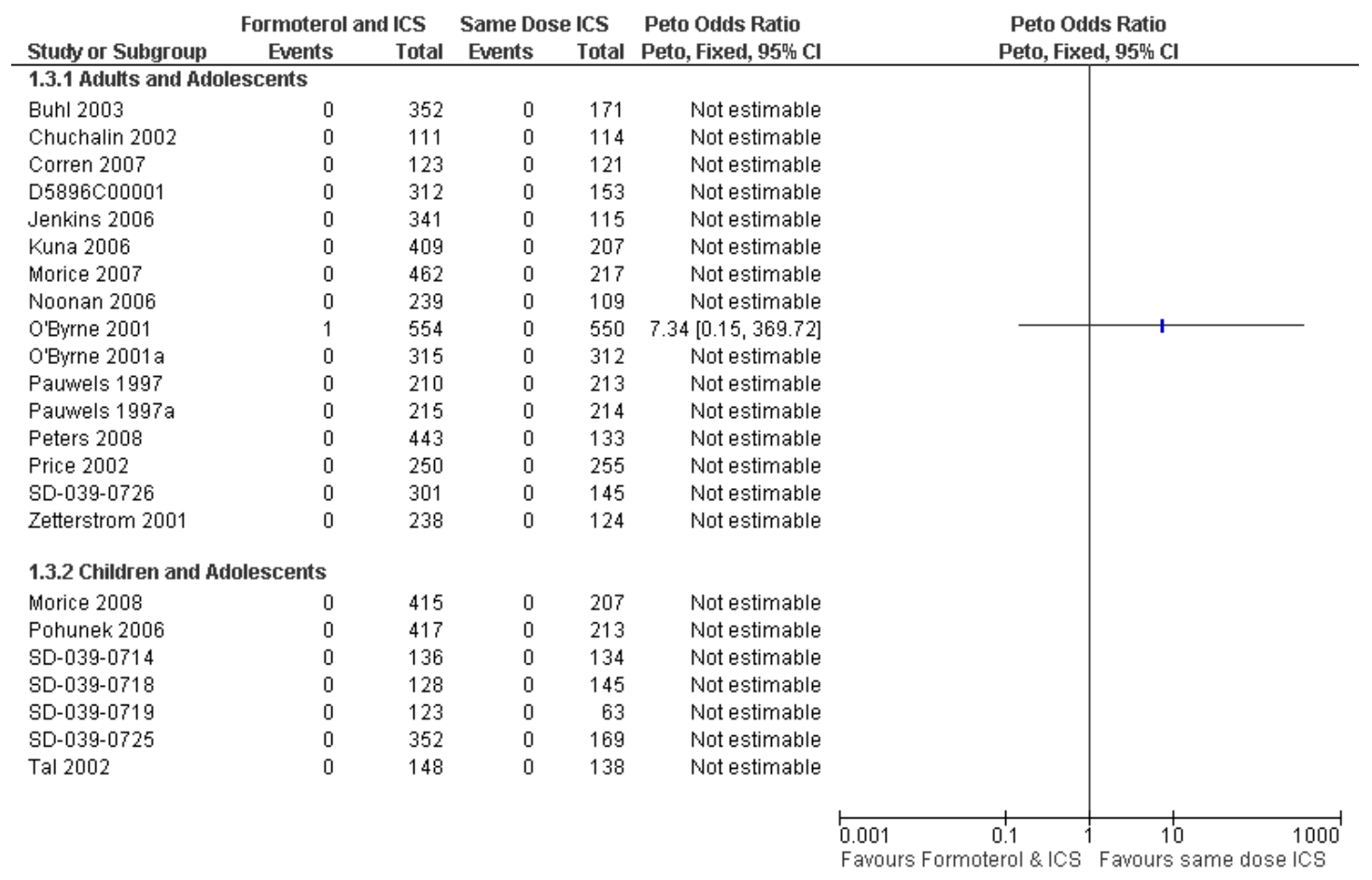

Serious Adverse Events related to Asthma

\section{All Ages}

The combined result in all ages was Peto Odds Ratio of 0.68 (95\% CI 0.39 to 1.18 ) and $\mathrm{I}^{2}$ was $21 \%$ Figure 7 , and the pooled RD for all ages was $-0.002(95 \% \mathrm{CI}-0.005$ to 0.001$)$ Figure 8. 
Figure 7. Forest plot of comparison: I Formoterol and ICS versus same dose ICS, outcome: I.4 Asthmarelated non-fatal Serious Adverse Events.

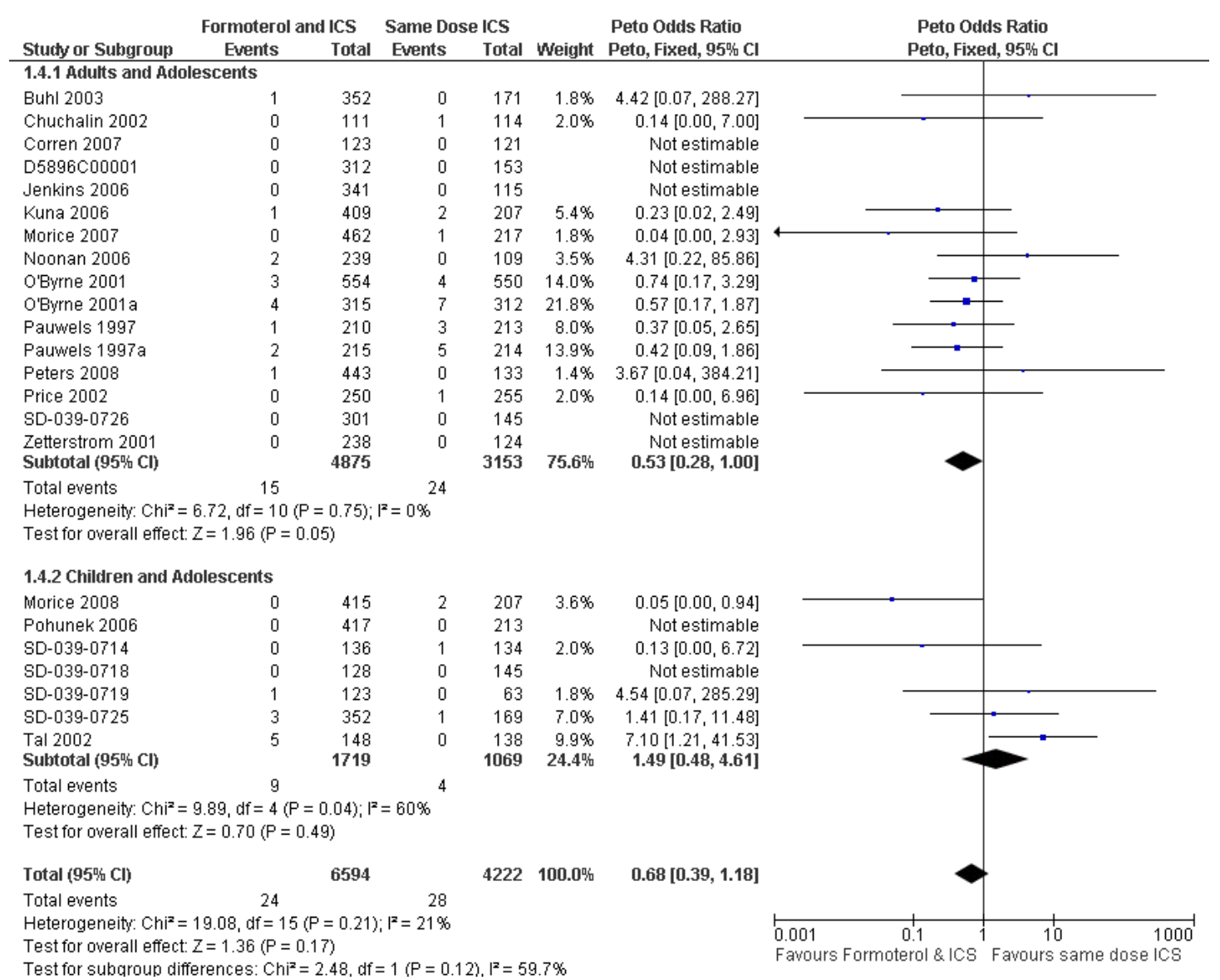


Figure 8. Forest plot of comparison: I Formoterol and ICS versus same dose ICS, outcome: I.7 Asthmarelated non-fatal Serious Adverse Events (Risk Difference).

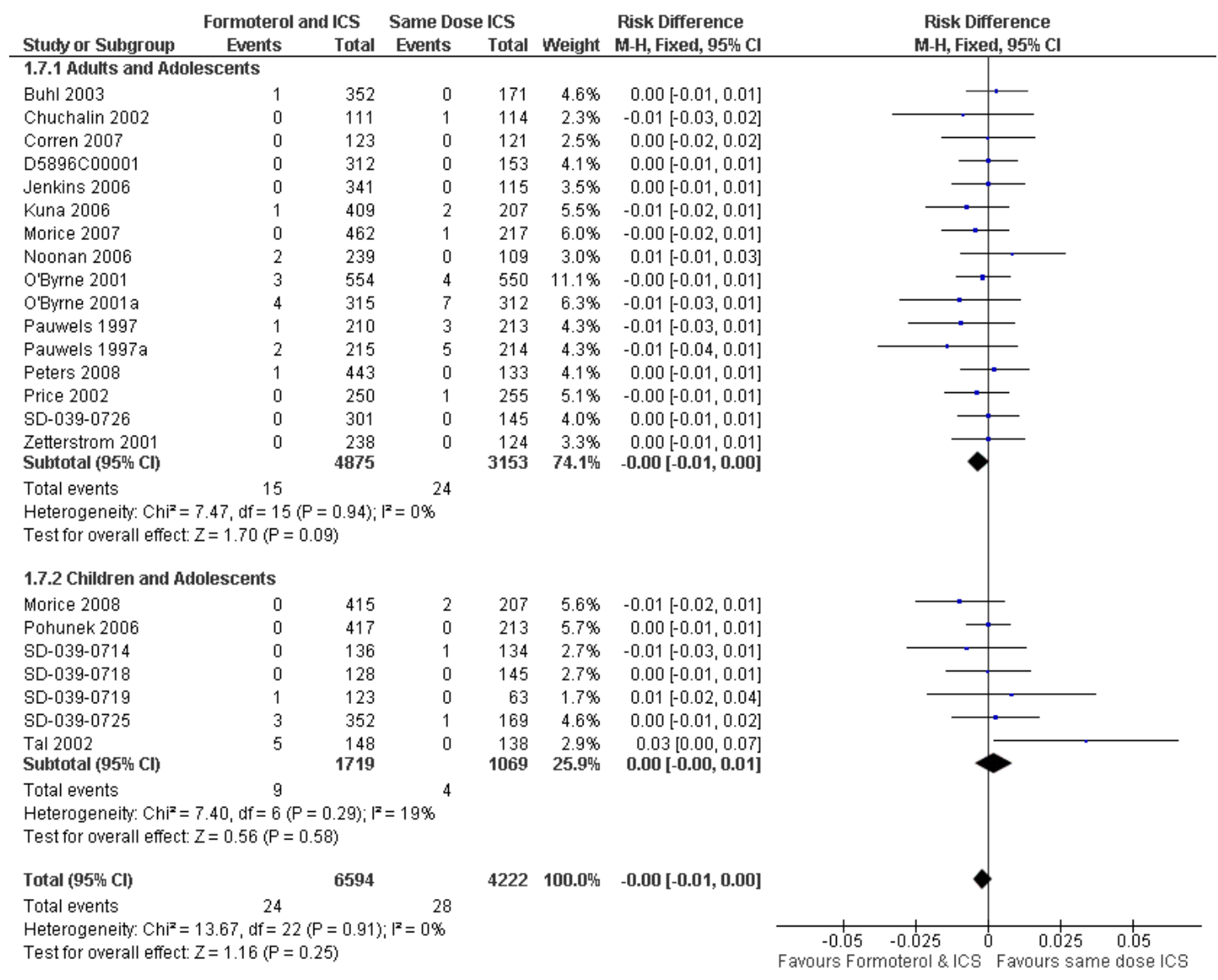

\section{Adults and Adolescents}

The number of patients experiencing one or more asthma related non-fatal serious adverse events was lower when formoterol was randomised with inhaled corticosteroids in comparison to inhaled corticosteroids alone, but the result was statistically significant using Peto Odds Ratio but not Risk Difference. There were 15 out of $4875(0.3 \%)$ participants on regular formoterol with ICS and 24 out of $3153(0.8 \%)$ on ICS alone. The Peto Odds Ratio was 0.53 (95\% CI 0.28 to 1.00$)$ and $\mathrm{I}^{2}$ was zero. The pooled RD was -0.003 (95\% CI -0.007 to 0.0005$)$.

\section{Children and Adolescents}

In the trials in patients who were less than 18 years of age the results were again more heterogeneous. There were 9 young people out of $1719(0.5 \%)$ on regular formoterol with ICS and four out of $1069(0.4 \%)$ on ICS alone. The Peto Odds Ratio showed a non-significant increase at $1.49(95 \% \mathrm{CI} 0.48$ to 4.61$)$ and $\mathrm{I}^{2}$ was $60 \%$. The pooled RD was 0.002 ( $95 \%$ CI -0.005 to 0.009 ).

The difference between children and adults was again not statistically significant. We did not find sufficient data to assess the other proposed secondary outcomes (such as ITU admission and intubation). There was one intubation (inhaled corticosteroid only group, O’Byrne 2001).

\section{Sensitivity Analyses}

\section{Risk of bias}

No deaths occurred in the unblinded study in children (SD-0390719) so exclusion of this study made no difference to mortality outcomes. When this study was excluded for non fatal serious adverse events, the Peto Odds Ratio for children was 1.69 (95\% 
CI 0.81 to 3.54 ) and $\mathrm{I}^{2}$ was $45 \%$ Figure 9. A funnel plot did not suggest obvious publication bias Figure 10 .

Figure 9. Forest plot of comparison: I Formoterol and ICS versus same dose ICS, outcome: I.I0 All-cause non-fatal Serious Adverse Events (sensitivity analysis without unblinded study).

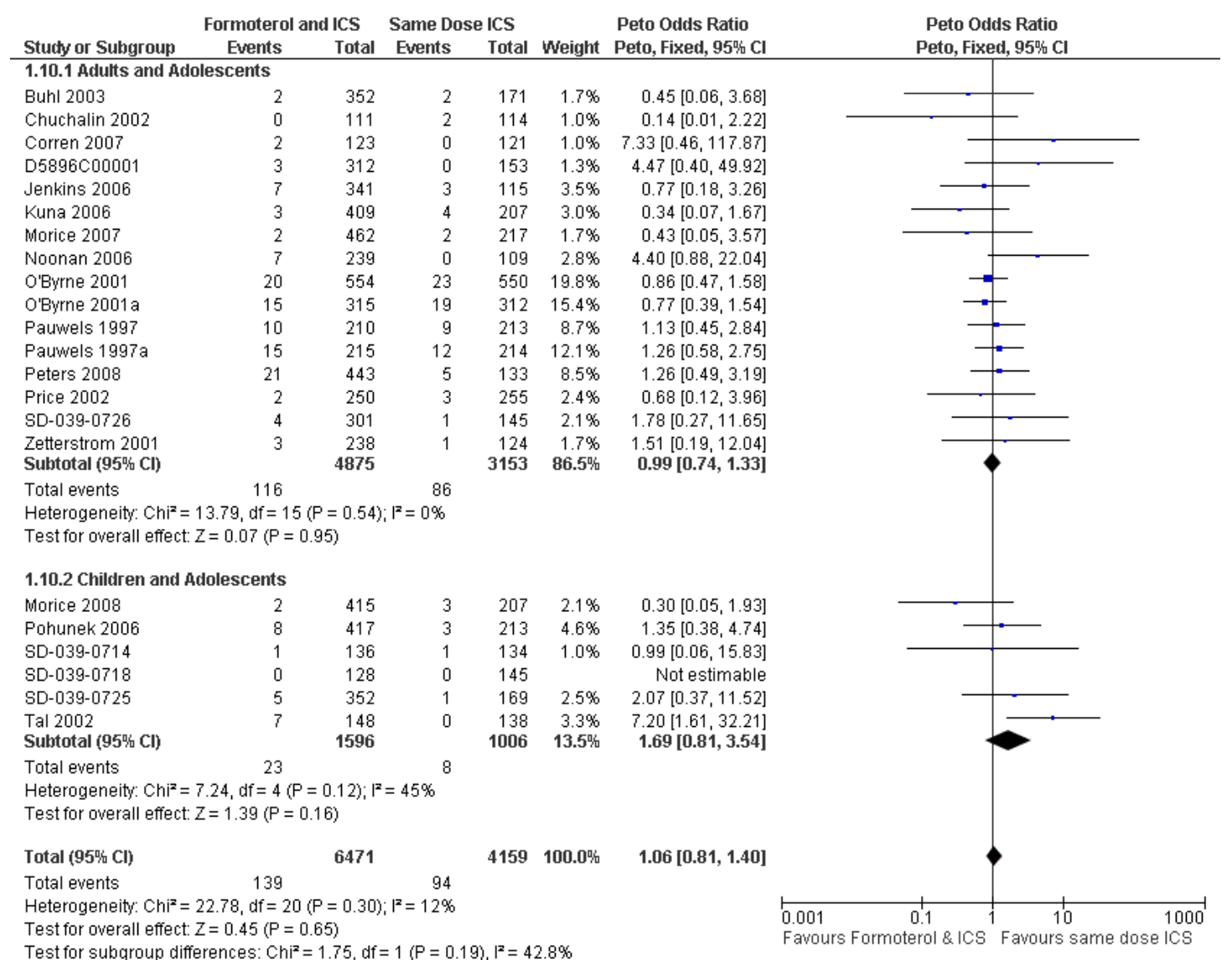


Figure 10. Funnel plot of comparison: I Formoterol and ICS versus same dose ICS, outcome: I.2 All-cause non-fatal Serious Adverse Events.

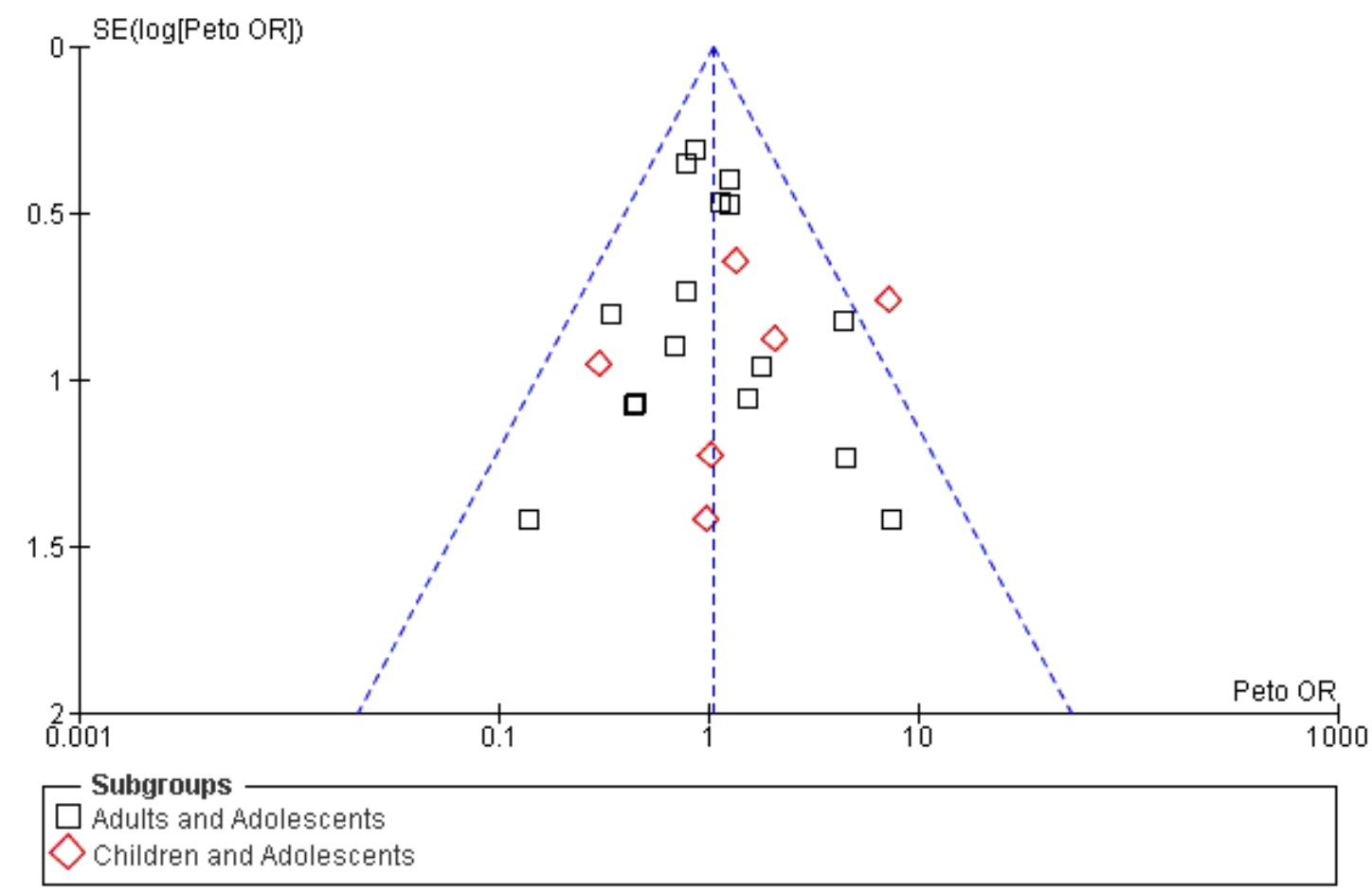

\section{Methods of analysis}

The primary outcomes were also analysed using Mantel-Haenszel fixed and random effects models. The results of the fixed effects model for mortality are shown in Figure 11. This method uses a correction for zero cells which means that the pooled OR is smaller than the Peto OR, since the addition of 0.5 to all cells when the arms have similar numbers randomised will generate an OR of 3 when there is only one event. When there are very sparse outcomes (such as for mortality), the results are entirely dependent on the size of the zero cell adjustment, and whether the treatment arms are balanced. For serious adverse events the Mantel-Haenszel fixed and random effects models gave almost identical results to the Peto method Figure 12. 
Figure II. Forest plot of comparison: I Formoterol and ICS versus same dose ICS, outcome: I.8 All-cause Mortality.

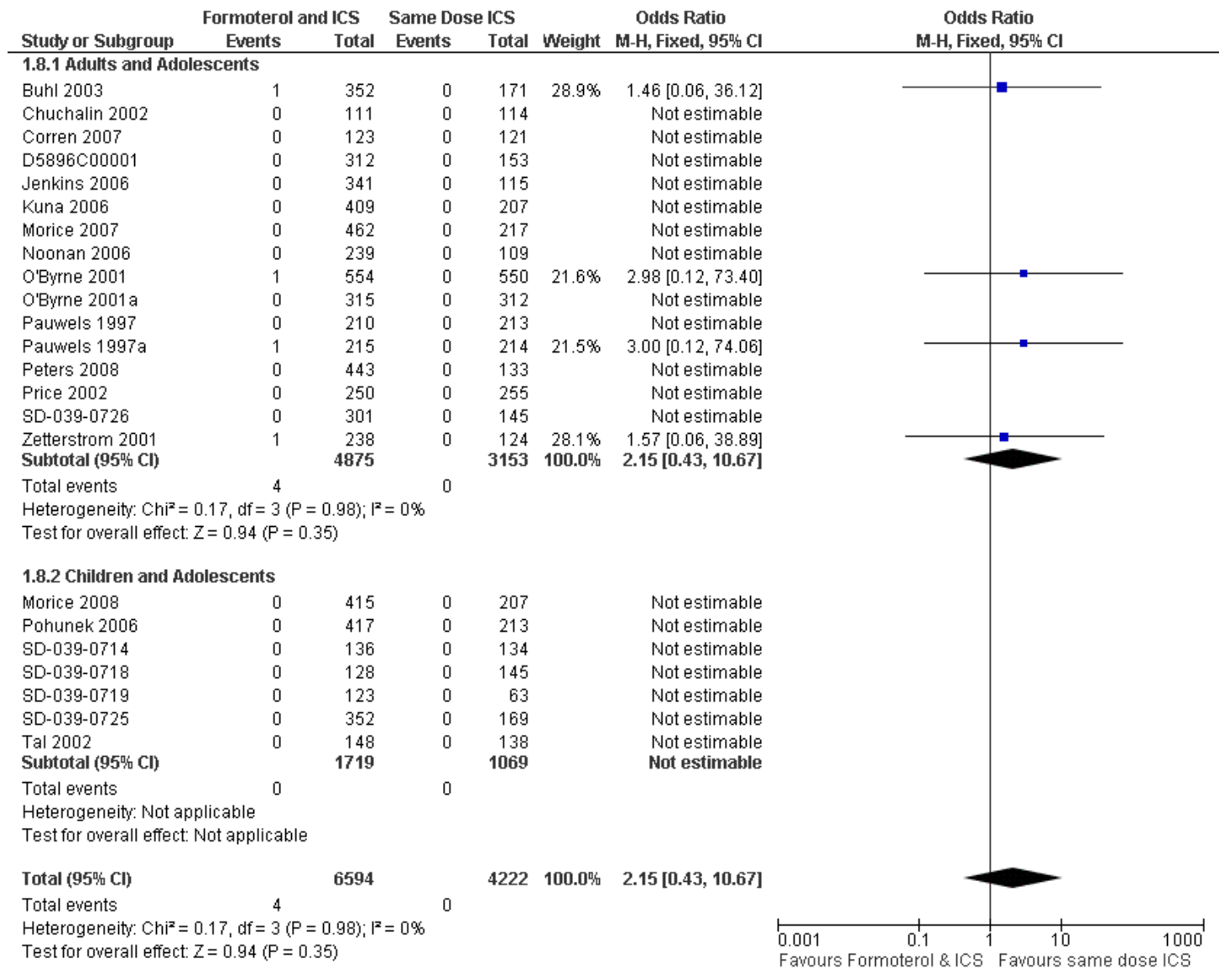


Figure 12. Forest plot of comparison: I Formoterol and ICS versus same dose ICS, outcome: I.9 All-cause non-fatal Serious Adverse Events.

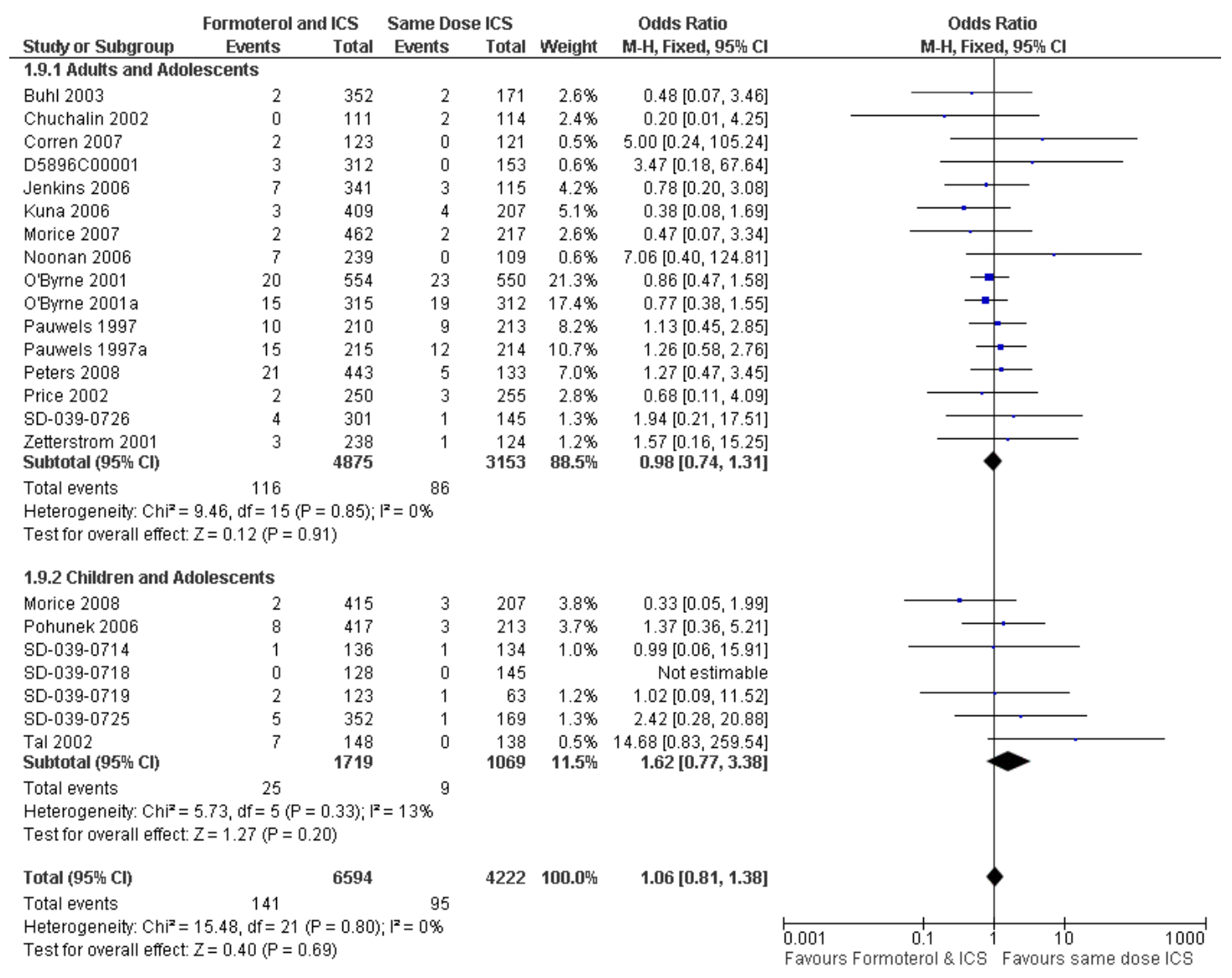

\section{Dose of formoterol}

The dose of formoterol used in all studies was within the licensed daily dose, so no sensitivity analysis was required to exclude unlicensed doses.

\section{Subgroup Analyses}

Mortality data were too sparse to carry out any sub-group analysis. Although the results for adults and children showed trends in opposite directions for non fatal serious adverse events (both allcause and asthma-related), the test for interaction did not show a significant interaction of treatment effect and age.

\section{Summary of main results}

\section{All cause mortality}

The confidence intervals for all cause mortality in adults indicate that for every thousand patients treated with regular formoterol and inhaled corticosteroids in comparison to inhaled corticosteroids alone we can expect something between three additional deaths and one less death in adults over 31 weeks of treatment, and at most four additional deaths to four less deaths in children over 13 weeks of treatment (the average duration of treatment in the respective trials). The pooled Peto Odds Ratio for adults was 5.83 (95\% confidence interval 0.78 to 43.77 ), and could not be calculated for children as there were no deaths in children. 
For non-fatal serious adverse events the limits of the pooled confidence interval are seven more to seven fewer adults and ten more to three fewer children for every thousand treated over the period of time represented in the trials. The Peto Odds Ratio was 0.99 ( $95 \%$ CI 0.74 to 1.33 ) for adults, and 1.62 (95\% CI 0.80 to 3.28 ) for children with heterogeneity present for the results of the studies in children.

\section{Overall completeness and applicability of evidence}

Two large studies have been carried out on the use of regular salmeterol (SMART 2006, SNS 1993), but the only large surveillance study on formoterol Pauwels 2003 (RELIEF) investigated its use as a reliever rather than as maintenance therapy and has therefore not been included in this review. This means that there is less data in this review to investigate the impact of formoterol on serious adverse events in comparison to our previous review on salmeterol (Cates 2008).

The small numbers of events in this review results in low precision of the estimates of relative risk between formoterol and control. However, outcome data were obtained from all the included studies and a funnel plot did not suggest publication bias.

\section{Quality of the evidence}

Risks of bias in the studies included in this review are thought to be low, as almost all the studies were double blind, and although allocation concealment was not well reported, it is likely to have been adequate as all the trials were sponsored or supported by AstraZeneca. Since the trials were carried out for regulatory purposes the collection of serious adverse event data will have been assessed using uniform definitions across the studies.

The level of heterogeneity within the subgroup of paediatric trials is significant $\left(\mathrm{I}^{2}=60 \%\right)$, and cannot be explained easily. The confidence intervals from two studies do not overlap (Morice 2008; Tal 2002), with the observed results indicating protection (Morice 2008), and harm (Tal 2002).

\section{Potential biases in the review process}

The selection of the best method to combine studies with rare events is contentious when event rates are low, not least because of the corrections required to calculate Odds Ratios with zero events
(Sweeting 2004). Since it became apparent in the course of the review that the pooled odds ratios were heavily dependent on the zero adjustment used in the Mantel-Haenszel and Inverse variance methods, we used the Peto Odds Ratio and risk differences to report results of this review. Since the imbalance between the trial arms is never more than two to one the likely bias in using the Peto Odds Ratio is small (Sweeting 2004).

Similarly the included studies were influenced by the decision to restrict the review to trials that randomised participants to formoterol and inhaled corticosteroids, but this decision reduces the risk of bias arising from patients discontinuing their usual inhaled steroid medication if they feel better on the randomised treatment. This presupposes a similar risk of SAEs when formoterol and budesonide are delivered via one inhaler, and when formoterol is introduced to ICS therapy via a separate inhaler, when both are randomised treatments in a controlled trial.

\section{Agreements and disagreements with other studies or reviews}

\section{Mortality}

Comparing the results from this review and the review on regular formoterol without randomised inhaled corticosteroids (Cates 2008a) indicates that all 7 deaths in the trials comparing formoterol to placebo or comparing formoterol with ICS to the same dose of ICS were in patients who were randomised to formoterol (with or without ICS), see Figure 13. This is a cause for concern, because although it may seem that many of the deaths were not related to asthma, it is often hard to be sure of the exact cause of death, and the classification of cause of death is not straightforward. For example the patient who died in OPTIMA (O'Byrne 2001) was recorded in the paper as dying from septic shock, but listed in Sears 2008 as status asthmaticus and septic shock, whereas the 13 year old boy who died in Von Berg 2003 is listed in Sears 2008 as dying of respiratory failure but the paper has reported that the cause of death was subarachnoid haemorrhage. Sears 2008 does not report all-cause mortality in the sub-group of trials in patients on regular formoterol and maintenance ICS; the primary analysis on all-cause mortality include the RELIEF study which allowed regular long-acting beta 2 -agonists in both arms and therefore was not included in this review. The adjusted all-cause mortality in Sears 2008 is RR $1.79(95 \%$ CI $0.80,4.00)$ when studies with any baseline ICS are considered; the conditional logistic regression was adjusted for trial effect (data on file provided by AstraZeneca). 
Figure 13. All cause mortality in trials of regular formoterol with or without ICS

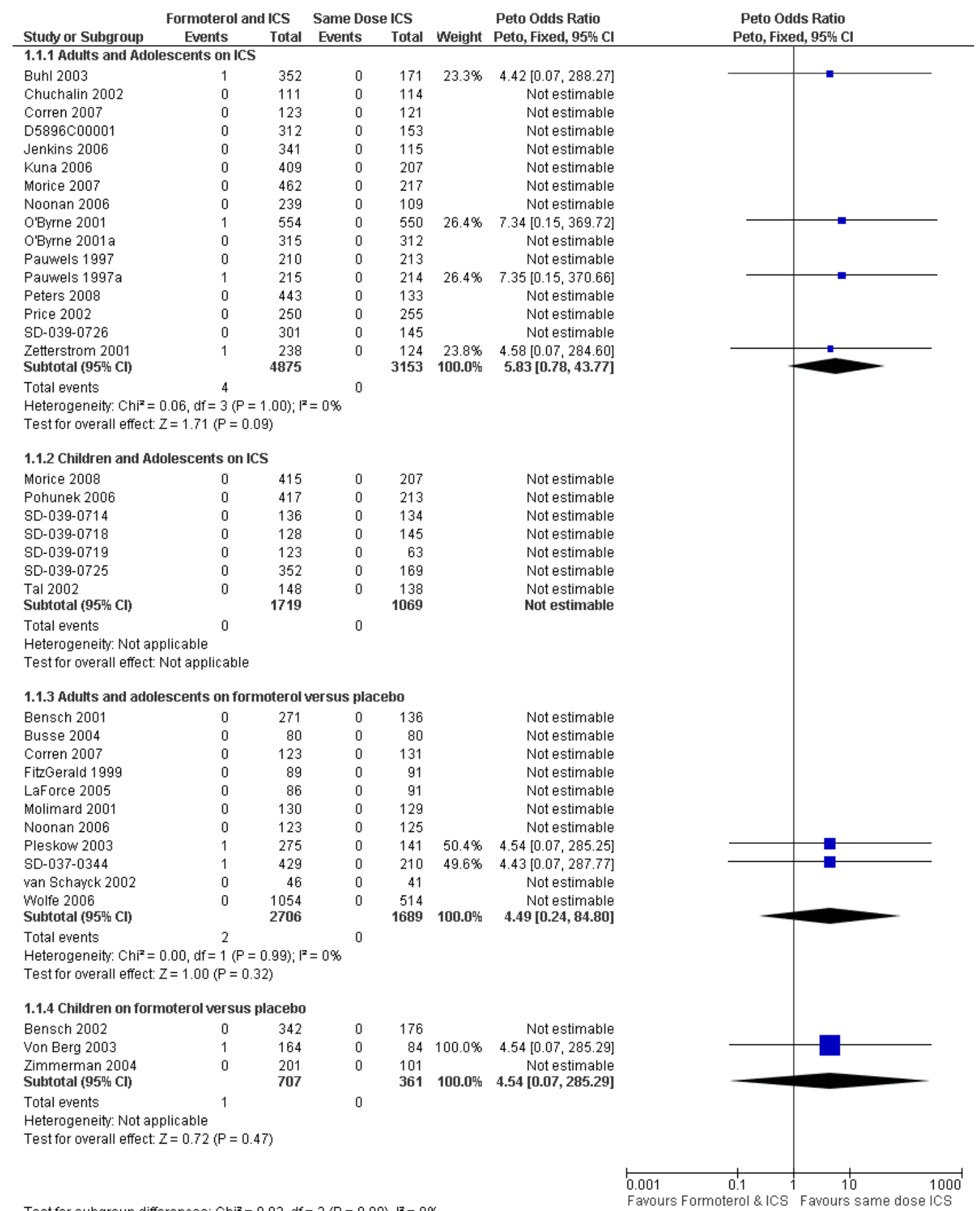

Test for subqroup differences: $\mathrm{Chi}^{2}=0.03, \mathrm{df}=2(\mathrm{P}=0.99), \mathrm{I}^{2}=0 \%$ 
Only one asthma related death was reported in this review, but the overview of Sears 2008 identified two further asthma-related deaths from the AstraZeneca database of trials in which participants were on maintenance ICS; all three deaths were in participants randomised to regular formoterol.

There were 6 additional death when formoterol and inhaled corticosteroids were compared to higher dose of inhaled corticosteroids - three deaths in each arm (Jaeschke 2008).

We agree with the conclusion of Sears 2008 that "the power is insufficient to conclude no increased mortality with formoterol" when regular formoterol is used in conjunction with ICS.

\section{All-cause non fatal serious adverse events}

Sears 2008 does not present data on all-cause serious adverse events, but Jaeschke 2008 has also found that the reduction in asthma-related serious adverse events and hospitalisations do not seem to translate into similar reductions in all-cause serious adverse events (which are about four times more common). Jaeschke 2008 and Jaeschke 2008a did not include trials in children. There is insufficient information from the trials in children in this review to determine whether the increased risk of non-fatal serious adverse events found on formoterol alone found in Cates 2008a (Peto OR 2.48; 95\% CI 1.27 to 4.83), is abolished by the addition of randomised inhaled corticosteroids (Peto OR 1.62; 95\% CI 0.80 to 3.28 ), as there is a large degree of overlap in the confidence intervals leading to a negative test for interaction, see Figure 14 .

Figure 14. All cause serious adverse events in children on regular formoterol (with or without ICS)

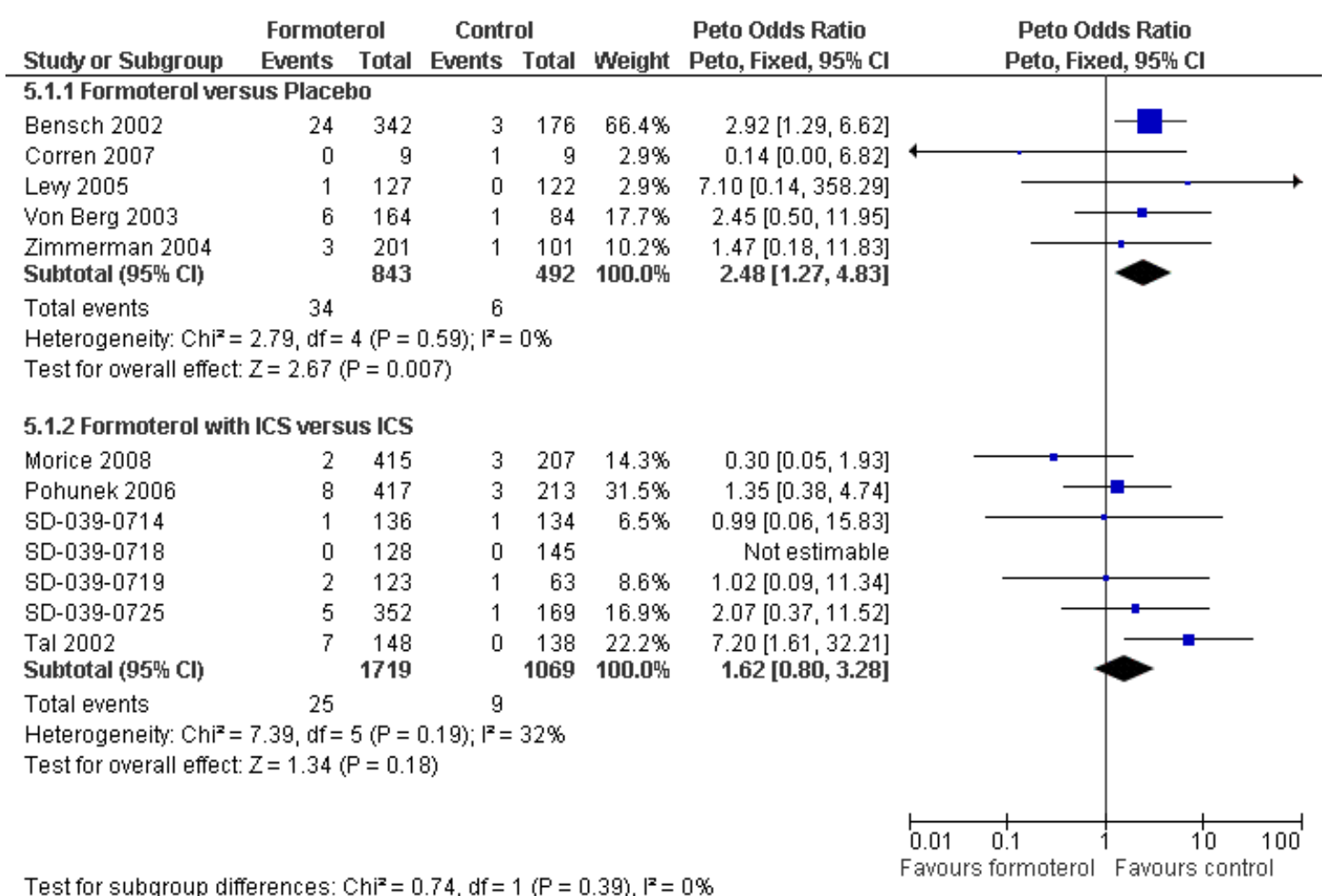

\section{Implications for practice}

\section{A U THORS, CONCLUSIONS}

It is not possible, from the data in this review, to reassure people with asthma that regular use of inhaled corticosteroids with for- 
inhaled corticosteroids alone as all four deaths occurred among 6,594 people using both drugs. On the other hand we have found no conclusive evidence of harm and there was only one asthma related death registered during over 3,000 patient years observation on formoterol. In adults, the decrease in asthma-related serious adverse events on regular formoterol with inhaled corticosteroids was not accompanied by a similar decrease in all cause serious adverse events. In children the number of events was too small to determine whether the increase in all cause non-fatal serious adverse events previously found on regular formoterol alone is abolished by the additional use of inhaled corticosteroids. Clinical decisions and information for patients regarding regular use of formoterol have to take into account the balance between known symptomatic benefits of formoterol and the degree of uncertainty and concern associated with its potential harmful effects.

\section{Implications for research}

Future research should clearly specify the number of patients with fatal and non-fatal serious adverse events by treatment group and cause. Any new surveillance study to investigate the impact of regular formoterol and inhaled corticosteroids on all-cause mortality would need to be very large.

\section{ACKNOWLEDGEMENTS}

We thank Susan Hansen of the Cochrane Airways Group for assistance in searching for trials and obtaining the abstracts and full reports, and extraction of data on trial characteristics. We also acknowledge the assistance of Matthew Cates in relation to the physiology of Beta-agonist receptors and co-writing of protocol. We thank Joe Gray, Finn Radner and Anders Ottosson of AstraZeneca for obtaining data on file for serious adverse events in some of the studies.

\section{RE F E R E N C E S}

\section{References to studies included in this review}

\section{Buhl 2003 \{published data only\}}

AstraZeneca. Symbicort High Dose Once Daily in Mild to Moderate Asthmatic Patients (SD-039-0666). http:/ /www.astrazenecaclinicaltrials.com/sites/133/imagebank/ typeArticleparam528362/SD-039-0666.pdf (accessed 26 November 2008).

* Buhl R, Creemers JP, Vondra V, Martelli NA, Naya IP, Ekstrom T. Once-daily budesonide/formoterol in a single inhaler in adults with moderate persistent asthma. Respiratory Medicine. 2003/04/16 2003; Vol. 97, issue 4: 323-30. [0954-6111: (Print)]

Buhl R, Creemers JPHM, Vondra V, Martelli NA. Improved and maintained asthma control with once-daily budesonide/ formoterol single inhaler in mild-to-moderate persistent asthma. European Respiratory Journal 2001;18(Suppl 33): 21s.

Buhl R, Creemers JPHM, Vondra V, Martelli NA. Oncedaily budesonide/formoterol via a single inhaler is effective in mild-to-moderate persistent asthma. European Respiratory Journal 2001;18(Supp 33):21s.

Buhl R, Creemers JPHM, Vondra V, Martelli NA. Once daily symbicort (budesonide/eformoterol in a single inhaler) is effective in moderate-persistent asthma. Thorax 2001;56 (Suppl 3):iii62.

Buhl R, Creemers JPHM, Vondra V, Martelli NA. Symbicort ${ }^{\circledR}$ budesonide and formoterol in a single inhaler administered once daily is effective in mild to moderate asthma. Annual Thoracic Society 97th International Conference; San Francisco CA ,May 18-23 2001:D31.

Chuchalin 2002 \{published data only\}

Chuchalin A, Stahl E, Svensson K, Ovcharenko S,
Goriachkina L, Sidorenko I, et al.Formoterol (oxis(r)) turbuhaler(r) plus budesonide turbuhaler(r) and budesonide alone improve health-related quality of life vs non-steroid therapy in mild to moderate asthma in Russia [abstract]. American Journal of Respiratory and Critical Care Medicine 2001;163(5 Suppl):A506.

Chuchalin AG, Ovcharenko SI, Goriachkina LA, Sidorenko IV, Tsoi AN. Formoterol Oxis ${ }^{\circledR}$ Turbuhaler ${ }^{\circledR}$ plus budesonide turbuhaler ${ }^{\circledR}$ is more effective than current non-steroid therapy and budesonide alone in mild to moderate asthma in Russia. Annual Thoracic Society 97th International Conference; San Francisco CA ,May 18-23. 2001:[D31].

* Chuchalin AG, Ovcharenko SI, Goriachkina LA, Sidorenko IV, Tsoi AN, Epoch Study G. The safety and efficacy of formoterol OxisRTurbuhalerR plus budesonide PulmicortRTurbuhaler in mild to moderate asthma: A comparison with budesonide Turbuhaler alone and current non-corticosteroid therapy in Russia. International Journal of Clinical Practice 2002; Vol. 56, issue 1:15-20.

Chuchalin A G, Svensson K, Stahl E, Ovcharenko S I, Goriachkina L A, Sidorenko I V, et al.A health-related quality-of-life comparison of formoterol (Oxis) Turbuhaler plus budesonide (Pulmicort) Turbuhaler with budesonide Turbuhaler alone and noncorticosteroid treatment in asthma: a randomized clinical study in Russia. Respiration 2002;69(5):427-33.

\section{Corren 2007 \{published data only\}}

AstraZeneca. SD-039-0716. A Twelve-Week, Randomized, Double-Blind, Double-Dummy, Placebo-Controlled Trialof SYMBICORT® pMDI $(80 / 4.5 \mu \mathrm{g})$ versus its Monoproducts (budesonide andformoterol) in Children 
( $\geq 6$ Years of Age) and Adults with Asthma - SPRUCE 80/ 4.5. http://www.astrazenecaclinicaltrials.com/sites/133/ imagebank/typeArticleparam528362/SD-039-0716.pdf accessed november 2008.

* Corren J, Korenblat PE, Miller CJ, O’Brien CD, Mezzanotte WS. Twelve-week, randomized, placebocontrolled, multicenter study of the efficacy and tolerability of budesonide and formoterol in one metered-dose inhaler compared with budesonide alone and formoterol alone in adolescents and adults with asthma. Clinical Therapeutics 2007; Vol. 29, issue 5:823-43.

Murphy K, Nelson H, Parasuraman B, Boggs R, Miller C, O'Dowd L. Patient satisfaction with budesonide and formoterol in one pressurized metered-dose inhaler in adults with mild to moderate persistent asthma [Abstract]. American Thoracic Society International Conference, May 18-23, 2007, San Francisco, California, USA 2007:Poster \# 928 .

Murphy K, Nelson H, Parasuraman B, Boggs R, Miller C, O'Dowd L. The effect of budesonide and formoterol in one pressurized metered-dose inhaler on patient-reported outcomes in adults with mild-to-moderate persistent asthma. Current Medical Research and Opinion 2008; Vol. 24, issue 3:879-94.

\section{D5896C00001 \{published data only\}}

* AstraZeneca. A randomized, double-blind, activecontrolled, parallel-group, singledummy,multicenter, 12 week study to assess the efficacy and safety ofSYMBICORT® pMDI 160/4.5 $\mu \mathrm{g}$ x 2 actuations once-daily (qd) comparedto SYMBICORT pMDI 80/ $4.5 \mu \mathrm{g}$ x 2 actuations qd, SYMBICORT pMDI80/4.5 $\mu \mathrm{g} \times 2$ actuations twice-daily (bid) and to budesonide pMDI $160 \mu \mathrm{gx} 2$ actuations qd in asthmatic subjects 12 years of age and older. [D5896C00001]. http:// www.astrazenecaclinicaltrials.com/sites/133/imagebank/ typeArticleparam528362/D5896C00001.pdf Accessed November 11th 2008.

Kerwin EM, Oppenheimer JJ, LaForce C, Miller CJ, O'Dowd L, Goldman M. Effects on pulmonary function of once-daily (qd) budesonide and formoterol administered via one pressurized metered-dose inhaler (pMDI) in adults and adolescents with asthma previously stable with twicedaily (bid) budesonide/formoterol pMDI. Journal of Allergy and Clinical Immunology 2008;121(2,Suppl 1):S152-3. LaForce C, Kerwin EM, Oppenheimer JJ, Miller CJ, Vervaet P, O'Dowd L, et al.Safety of once-daily (qd) budesonide and formoterol administered via one pressurized metered-dose inhaler (pMDI) in adults and adolescents with asthma previously stable With twice-daily (bid) budesonide/formoterol pMDI. Journal of Allergy and Clinical Immunology 2008;121(2, Suppl 1):S153.

Oppenheimer JJ, Kerwin EM, LaForce C, Miller CJ, O’Dowd L, Goldman M. Asthma Control with Once-Daily (qd) Budesonide/Formoterol Pressurized Metered-Dose Inhaler (pMDI) in Adults and Adolescents with Asthma Previously Stable with Twice-Daily (bid) Budesonide/ Formoterol pMDI. Journal of Allergy and Clinical
Immunology 2008;121(2, Supplement 1):S8.

\section{Jenkins 2006 \{published data only\}}

AstraZeneca. Efficacy and safety of Symbicort ${ }^{\circledR}$ (budesonide/ formoterol) 1280/36 mcg daily delivered dose compared to Pulmicort ${ }^{\circledR}$ (budesonide) $1600 \mathrm{mcg}$ metered dose and Pulmicort (budesonide) $1600 \mathrm{mcg}$ metered dose plus Oxis ${ }^{\circledR}$ (formoterol) $36 \mathrm{mcg}$ delivered dose all delivered via Turbuhaler ${ }^{\circledR}$ in steroid-using asthmatic adolescents and adults. A double-blind, double-dummy, randomized, parallel group, phase III, multicentre study. (SD-0390689). http://www.astrazenecaclinicaltrials.com/sites/133/ imagebank/typeArticleparam528362/SD-039-0689.pdfs (accessed 26 November 2008).

* Jenkins C, Kolarikova R, Kuna P, Caillaud D, Sanchis J, Popp W, et al.Efficacy and safety of high-dose budesonide/ formoterol (Symbicort) compared with budesonide administered either concomitantly with formoterol or alone in patients with persistent symptomatic asthma. Respirology 2006; Vol. 11, issue 3:276-86.

Jenkins C, Kolarikova R, Kuna P, Caillaud D, Sanchis J, Popp W, et al.Symbicort ${ }^{\circledR}$ turbuhaler ${ }^{\circledR}$ offers an effective and well tolerated treatment for patients with moderate to severe asthma [abstract]. American Thoracic Society 99th International Conference. 2003:D034 Poster C37.

\section{Kuna 2006 \{published data only\}}

AstraZeneca. Symbicort Low Dose Once Daily In Mild To Moderate Asthmatic Patients (SD-039-0665). http:/ /www.astrazenecaclinicaltrials.com/sites/133/imagebank/ typeArticleparam528362/SD-039-0665.pdf (accessed 26 November 2008).

Kuna P, Chuchalin A, Ringdal N, De la Padilla EA, Black P, Lindqvist A, et al.Low-dose single-inhaler budesonide/ formoterol administered once daily is effective in mildpersistent asthma. European Respiratory Journal 2001;18 (Suppl 33):158s.

* Kuna P, Creemers J, Vondra V, Black PN, Lindqvist A, Nihlen U, et al.Once-daily dosing with budesonide/ formoterol compared with twice-daily budesonide/ formoterol and once-daily budesonide in adults with mild to moderate asthma. Respiratory Medicine 2006; Vol. 100, issue 12:2151-9.

\section{Morice 2007 \{published data only\}}

AstraZeneca. A randomised, double-blind, parallel-group, multicentre phase-III study to compare the efficacy and safety of Symbicort ${ }^{\circledR}$ pMDI (budesonide/formoterol 160/ $4.5 \mathrm{~g} 2$ actuations b.i.d., delivered dose) with that of Pulmicort ${ }^{\circledR}$ pMDI (budesonide $200 \mathrm{~g} 2$ actuations b.i.d., metered dose) and Symbicort Turbuhaler ${ }^{\circledR}$ (budesonide/ formoterol 160/4.5 g 2 inhalations b.i.d., delivered dose) in adolescents and adults with asthma (SD-039-0681). http: //www.astrazenecaclinicaltrials.com/sites/133/imagebank/ typeArticleparam528362/SD-039-0681.pdf (accessed 26 November 2008).

Morice AH, Hochmuth L, Puterman A, Artheden L, Beckman O. Comparable safety of a novel budesonide/ formoterol pMDI versus budesonide/formoterol Turbuhaler in adolescents and adults with asthma [Abstract]. Journal 
of Allergy \& Clinical Immunology 2005; Vol. 115, issue 2 Suppl:S3.

* Morice AH, Peterson S, Beckman O, Osmanliev D. Therapeutic comparison of a new budesonide/formoterol pMDI with budesonide pMDI and budesonide/formoterol DPI in asthma. International Journal of Clinical Practice. 2007/09/25 2007; Vol. 61, issue 11:1874-83. [1368-5031: (Print)]

\section{Morice 2008 \{published data only\}}

AstraZeneca. A 12-week randomised, double-blind, parallel-group, multicentre phase-III study to compare the efficacy and safety of Symbicort ${ }^{\circledR}$ pMDI (budesonide/ formoterol 80/4.5 $\mu \mathrm{g} 2$ actuations b.i.d., delivered dose) with that of Pulmicort ${ }^{\circledR}$ pMDI (budesonide $100 \mu \mathrm{g} 2$ actuations b.i.d., metered dose) and Symbicort Turbuhaler ${ }^{\circledR}$ (budesonide/formoterol 80/4.5 $\mu \mathrm{g} 2$ actuations b.i.d., delivered dose) in children with asthma (SD-0390682). http://www.astrazenecaclinicaltrials.com/sites/133/ imagebank/typeArticleparam528362/SD-039-0682.pdf (accessed 26 November 2008).

* Morice AH, Peterson S, Beckman O, Kukova Z. Efficacy and safety of a new pressurised metered-dose inhaler formulation of budesonide/formoterol in children with asthma: a superiority and therapeutic equivalence study. Pulmonary Pharmacology and Therapeutics. 2007/03/23 2008; Vol. 21, issue 1:152-9. [1094-5539: (Print)]

Noonan 2006 \{published data only\}

AstraZeneca. A Twelve-Week, Randomized, DoubleBlind, Double-Dummy, Placebo-Controlled Trial of SYMBICORT® (160/4.5 ìg) versus its Mono-Products (budesonide and formoterol) in Adolescents (.12 Years of Age) and Adults with Asthma International (SD-0390717). http://www.astrazenecaclinicaltrials.com/sites/133/ imagebank/typeArticleparam528362/SD-039-0717.pdf (accessed 26 November 2008).

Baker J, Martin P, Parasuraman B. Patient satisfaction with budesonide and formoterol in one pressurized metereddose inhaler in patients with asthma. Chest 2007;132(4): 509b-510.

* Noonan M, Rosenwasser LJ, Martin P, O’Brien CD, O'Dowd L. Efficacy and safety of budesonide and formoterol in one pressurised metered-dose inhaler in adults and adolescents with moderate to severe asthma: A randomised clinical trial. Drugs 2006; Vol. 66, issue 17: $2235-54$.

\section{O'Byrne 2001 \{published data only\}}

Barnes PJ, O’Byrne PM, Rodriguez Roisin R, Runnerstrom E, Sandstrom T, Svensson K, et al.Treatment of mild persistent asthma with low doses of inhaled Budesonide alone or in combination with Formoterol. Thorax 2000;55 (Suppl 3):A4.

Grosser D, Smith B. Low-dose budesonide improved asthma control in mild asthma; adding formoterol improved control in corticosteroid-treated patients. ACP Journal Club. 2002;137(1):19.

Jonsson B, Berggren F, Svensson K, O’Byrne PM. An economic evaluation of combination treatment with budesonide and formoterol in patients with mild-tomoderate persistent asthma. Respiratory Medicine 2004;98 (11):1146-54.

Jönsson BG, Berggren FE, Svensson K, O’Byrne PM. Budesonide and formoterol in mild persistent asthma compared with doubling the dose of budesonide - a costeffectiveness analysis. European Respiratory Journal 2001;18 (Suppl 33):517s.

Jönsson BG, Berggren FE, Svensson K, O’Byrne PM. Economic results of adding formoterol to budesonide in mild persistent asthma. European Respiratory Journal 2001; 18(Suppl 33):331s.

* O'Byrne PM, Barnes PJ, Rodriguez-Roisin R, Runnerstrom EVA, Sandstrom T, Svensson K, et al.Low Dose Inhaled Budesonide and Formoterol in Mild Persistent Asthma . The OPTIMA Randomized Trial. American Journal of Respiratory and Critical Care Medicine 2001; Vol. 164, issue 8:1392-7.

O’Byrne PM, Barnes PJ, Rodriguez-Roisin R, Sandtröm $T$, Tattersfield AE, Runnerström EM, et al.Addition of formoterol Turbuhaler(r) to budesonide Tubuhaler $(r)$ is safe and well tolerated in the long-term treatment of mild asthma: results from the OPTIMA trial. European Respiratory Journal 2001;18(Supp 33):330s.

\section{O'Byrne 2001a \{published data only\}}

* O’Byrne PM, Barnes PJ, Rodriguez-Roisin R, Runnerstrom EVA, Sandstrom T, Svensson K, et al.Low Dose Inhaled Budesonide and Formoterol in Mild Persistent Asthma . The OPTIMA Randomized Trial. American Journal of Respiratory and Critical Care Medicine 2001; Vol. 164, issue 8:1392-7.

\section{Pauwels 1997 \{published data only\}}

Juniper EF, Svensson K, O'Byrne PM, Barnes PJ, Bauer CA, Lofdahl CGA, et al.Asthma quality of life during 1 year of treatment with budesonide with or without formoterol. European Respiratory Journal 1999;14(5):1038-43. Pauwels R. Additive effects of inhaled formoterol and budesonide in reducing asthma exacerbations. [Review] [4 refs]. Allergy 1998;53(42 Suppl):20-3.

* Pauwels RA, Lofdahl CG, Postma DS, Tattersfield AE, O'Byrne P, Barnes PJ, et al.Effect of inhaled formoterol and budesonide on exacerbations of asthma. Formoterol and Corticosteroids Establishing Therapy (FACET) International Study Group. New England Journal of Medicine. 1997/11/14 1997; Vol. 337, issue 20:1405-11. [0028-4793: (Print)]

Tattersfield AE, Postma DS, Barnes PJ, Svensson K, Bauer CA, O'Byrne PM, et al.Exacerbations of asthma: a descriptive study of 425 severe exacerbations. The FACET International Study Group. American Journal of Respiratory and Critical Care Medicine 1999;160(2):594-9.

Pauwels 1997a \{published data only\}

* Pauwels RA, Lofdahl CG, Postma DS, Tattersfield AE, O’Byrne P, Barnes PJ, et al.Effect of inhaled formoterol and budesonide on exacerbations of asthma. Formoterol and Corticosteroids Establishing Therapy (FACET) International Study Group [New England Journal of 
Medicine]. N Engl J Med. 1997/11/14 1997; Vol. 337, issue 20:1405-11. [0028-4793: (Print)]

\section{Peters 2008 \{published and unpublished data\}}

AstraZeneca. A 52-week, randomized, double-blind, single-dummy, parallel-group, multicenter Phase III study comparing the long-term safety of SYMBICORT ${ }^{\circledR}$ pMDI $160 / 4.5$ ig $x 4$ actuations twice daily to SYMBICORT® pMDI 160/4.5 ìg x 2 actuations twice daily and budesonide HFA pMDI 160 ig x 4 actuations twice daily in adult and adolescent subjects with asthma (SD-039-0728). http:/ /www.astrazenecaclinicaltrials.com/sites/133/imagebank/ typeArticleparam528362/SD_039_0728.pdf (acccessed 26 November 2008).

O'Brien CD, Peters SP, Prenner BM, Martin P. Long-term safety of budesonide/formoterol pressurized metered-dose inhaler (BUD/FM pMDI) in asthma patients: adverse events and asthma exacerbations [Abstract]. American Thoracic Society International Conference, May 18-23, 2007, San Francisco, California, USA. 2007:Poster \#L57. O'Brien CD, Peters SP, Prenner BM, Martin P. Resource use with budesonide/formoterol pressurized metereddose inhaler (BUD/FM pMDI) versus BUD pMDI in asthma patients [Abstract]. American Thoracic Society International Conference, May 18-23, 2007, San Francisco, California, USA. 2007:Poster \#L58.

Peters SP, Prenner BM, Martin P, O’Brien CD. Longterm effects on lung function of budesonide (BUD) and formoterol (FM) in one pressurized metered-dose inhaler (BUD/FM pMDI) and BUD pMDI in patients with asthma [Abstract]. American Thoracic Society International Conference, May 18-23, 2007, San Francisco, California, USA. 2007:Poster \#K5.

* Peters SP, Prenner BM, Mezzanotte WS, Martin P, O’Brien $\mathrm{CD}$. Long-term safety and asthma control with budesonide/ formoterol versus budesonide pressurised metered-dose inhaler in asthma. Allergy and Asthma Proceedings 2008;29: $1-18$.

Prenner BM, Peters SP, Martin P, O’Brien CD. Long-term control of asthma symptoms with budesonide/formoterol pressurized metered-dose inhaler (BUD/FM pMDI) versus BUD pMDI [Abstract]. American Thoracic Society International Conference, May 18-23, 2007, San Francisco, California, USA. 2007:Poster \#L67.

Prenner BM, Peters SP, Martin P, O'Brien CD. Safety pharmacodynamics (PD) of budesonide/formoterol (BUD/ FM) pMDI in asthma patients [Abstract]. American Thoracic Society International Conference, May 18-23, 2007, San Francisco, California, USA. 2007:Poster \#L66.

Pohunek 2006 \{published data only\}

AstraZeneca. Efficacy and safety of Symbicort ${ }^{\circledR}$ (budesonide/formoterol 80/4.5 $\mu$ g, 2 inhal. b.i.d.) compared to Pulmicort ${ }^{\circledR}$ (budesonide $100 \mathrm{mcg}, 2$ inhal. b.i.d.) and Pulmicort (budesonide $100 \mu \mathrm{g}, 2$ inhal. b.i.d.) plus $\mathrm{Oxis}{ }^{\circledR}$ (formoterol $4.5 \mu \mathrm{g}, 2$ inhal. b.i.d.) all delivered via Turbuhaler ${ }^{\circledR}$ in steroid using asthmatic children. A double-blind, double-dummy, randomised, parallel-group, phase III, multicentre 12-week study (SD-039-0688). http: //www.astrazenecaclinicaltrials.com/sites/133/imagebank/ typeArticleparam528362/SD-039-0688.pdf (accessed 26 November 2008) 2003.

Pohunek P, Kuna P, De Boeck K. Budesonide/formoterol improves lung function compared with budesonide alone in children with asthma [Abstract]. European Respiratory Journal 2004;24(Suppl 48):379s.

* Pohunek P, Kuna P, Jorup C, De Boeck K. Budesonide/ formoterol improves lung function compared with budesonide alone in children with asthma. Pediatric Allergy \& Immunology 2006; Vol. 17, issue 6:458-65. Pohunek P, Matulka M, Rybnicek O, Kopriva F, Honomichlova H, Svobodova T. Dose-related efficacy and safety of formoterol (Oxis) Turbuhaler compared with salmeterol Diskhaler in children with asthma. Pediatric Allergy \& Immunology 2004;15(1):32-9.

Price 2002 \{published data only\}

* Price D, Dutchman D, Mawson A, Bodalia B, Duggan $S$, Todd P. Early asthma control and maintenance with eformoterol following reduction of inhaled corticosteroid dose. Thorax. 2002/08/30 2002; Vol. 57, issue 9:791-8. [0040-6376: (Print)]

Price MJ, Briggs AH. Development of an economic model to assess the cost effectiveness of asthma management strategies. Pharmacoeconomics. 2002;20(3):183-94. Price MJ, Sondhi S, Yan S, Nyth A, House K. Salmeterol/ fluticasone propionate combination inhaler is more cost effective than fluticasone propionate in patients with asthma. European Respiratory Society; 1999 Oct 9-13; Madrid, Spain. 1999:[P2459].

SD-039-0714 \{unpublished data only\}

* AstraZeneca. Efficacy and safety of budesonide/ formoterol Turbuhaler® (160/4.5 mg b.i.d.delivered dose) compared to budesonide Turbuhaler ${ }^{\circledR}$ (200 mg b.i.d. metereddose) in steroid-using asthmatic adolescent patients. A double-blind, doubledummy,randomised, parallel group, phase III, multicentre study. (ATTAINSTUDY). http:/ /www.astrazenecaclinicaltrials.com/sites/133/imagebank/ typeArticleparam528362/SD-039-0714.pdf Accessed November 142008.

SD-039-0718 \{unpublished data only\}

* AstraZeneca. A Twelve-Week, Randomized, DoubleBlind, Double-Dummy Trial ofSymbicort ${ }^{\circledR}(40 / 4.5 \mathrm{mcg})$ versus its Mono-Products (budesonide and formoterol) in Asthmatic Children Aged Six to Fifteen Years.. http: //www.astrazenecaclinicaltrials.com/sites/133/imagebank/ typeArticleparam528362/SD-039-0718.pdf Accessed November 142008.

SD-039-0719 \{unpublished data only\}

* AstraZeneca. A Six-Month, Randomized, Open-Label Safety Study of SYMBICORT® $(160 / 4.5 \mu \mathrm{g})$ Compared to PULMICORT Turbuhaler ${ }^{\circledR}$ in AsthmaticChildren Aged 6 to 11 Years.. http://www.astrazenecaclinicaltrials.com/ sites/133/imagebank/typeArticleparam528362/SD-0390719.pdf Accessed November 142008.

Berger WE, Leflein JG, Uryniak T, O'Brien CD, O'Dowd L. Long-term efficacy and resource utilization after treatment 
with budesonide and formoterol administered via one pressurized metered-dose inhaler (pMDI) compared With budesonide dry powder inhaler (DPI) alone in children with asthma. Journal of Allergy and Clinical Immunology 2008;121(2, Suppl 1):S8.

Leflein JG, Berger WE, Uryniak T, Vervaet P, O’Dowd $\mathrm{L}$, O'Brien CD. Long-term safety and systemic effects of budesonide and formoterol administered via one pressurized metered-dose inhaler (pMDI) in children with asthma. Journal of Allergy and Clinical Immunology 2008;121(2, Suppl 1):S155.

O'Dowd L, Berger WE, Leflein JG, Uryniak T, Parasuraman B, O'Brien CD. Health-related quality of life (HRQL) and asthma control after long-term treatment with budesonide and formoterol administered via one pressurized metereddose inhaler ( $\mathrm{pMDI}$ ) compared with budesonide dry powder inhaler (DPI) alone in children with asthma. Journal of Allergy and Clinical Immunology 2008;121(2, Suppl 1):S152.

\section{SD-039-0725 \{unpublished data only\}}

* AstraZeneca. A Twelve-Week, Randomized, Doubleblind, Double-Dummy, Active-Controlled Study ofSYMBICORT® pMDI Administered Once Daily in Children and Adolescents 6 to 15Years of Age with Asthma. http://www.astrazenecaclinicaltrials.com/sites/133/ imagebank/typeArticleparam528362/SD_039_0725.pdf Accessed November 182008.

\section{SD-039-0726 \{unpublished data only\}}

* AstraZeneca. A Twelve-Week, Randomized, DoubleBlind, Double-Dummy, Placebo- and Active-Controlled Study of SYMBICORT® pMDI Administered Once Daily in Adults andAdolescents with Asthma.. http:// www.astrazenecaclinicaltrials.com/sites/133/imagebank/ typeArticleparam528362/SD-039-0726.pdf Accessed November 142008.

\section{Tal 2002 \{published data only\}}

AstraZeneca. Efficacy and safety of budesonide/formoterol Turbuhaler ${ }^{\circledR}$ in a fixed combination in steroid-using asthmatic children - COMIC (SD-039-0353). http:// www.astrazenecaclinicaltrials.com/sites/133/imagebank/ typeArticleparam528362/SD-039-0353.pdf (accessed 26 November 2008)

Tal A, Simon G, Vermeulen JH. Symbicort ${ }^{\circledR}$ Budesonide and formoterol in a single inhaler is effective and well tolerated in children with asthma. Annual Thoracic Society 97th International Conference; San Francisco CA ,May 1823. 2001:D29.

* Tal A, Simon G, Vermeulen JH, Petru V, Cobos N, Everard ML, et al.Budesonide/formoterol in a single inhaler versus inhaled corticosteroids alone in the treatment of asthma. Pediatric Pulmonology 2002; Vol. 34, issue 5: 342-50.

Tal A, Simon G, Vermeulen JH, Petru V, Cobos N, Everard $\mathrm{ML}$, et al.Rapid and sustained improvements in lung function and symptom control with budesonide/ formoterol in adolescent asthma. European Respiratory Journal 2001;18
(Suppl 33):494s.

Tal A, Simon G, Vermeulen JH, Petru V, Cobos N, Everard $\mathrm{ML}$, et al.Symbicort budesonide and formoterol in a single inhaler is more effective that budesonide alone in children with asthma. International Paediatric Respiratory and Allergy Congress, April 1-4; Prague. 2001:84-5. Tal A, Simon G, Vermeulen JH, Vit P, Cobos N, Everard $\mathrm{ML}$, et al. The benefit of the new single inhaler product containing both budesonide and formeterol in asthmatic children. European Respiratory Journal 2000;16(Supplement 31):384s.

Vermeulen JH, Simon G, Tal A. Symbicort ${ }^{\circledR}$ Budesonide and formoterol in a single inhaler improves lung function in asthmatic children aged 4-17 years. Annual Thoracic Society 97th International Conference; San Francisco CA, May 18-23. 2001:D29.

\section{Zetterstrom 2001 \{published data only\}}

AstraZeneca. Efficacy and safety of a fixed combination of budesonide/formoterol Turbuhaler ${ }^{\circledR}$ in inhaled steroid-using asthmatic adults. (SD-039-0349). http:// www.astrazenecaclinicaltrials.com/sites/133/imagebank/ typeArticleparam528362/SD-039-0349.pdf (accessed 26 November 2008).

Buhl R, Zetterstrom O, Mellem H, Perpina M, Hedman J, O'Neill S, et al.Improved asthma control with budesonide/ formoterol via a single inhaler compared with budesonide alone, in moderate persistent asthma. European Respiratory Journal 2001;18(Suppl 33):48s.

Zetterstrom O, Buhl R, Mellem H. Efficacy and safety of symbicort ${ }^{\circledR}$ budesonide and formoterol in a single inhaler in adults with asthma. Annual Thoracic Society 97th International Conference; San Francisco CA ,May 18-23. 2001.

* Zetterstrom O, Buhl R, Mellem H, Perpina M, Hedman J, O'Neill S, et al.Improved asthma control with budesonide/ formoterol in a single inhaler, compared with budesonide alone. European Respiratory Journal 2001; Vol. 18, issue 2: 262-8.

Zetterström O, Buhl R, Mellem H, Perpiñá M, Hedman J, O'Neill S, et al.Efficacy and safety of a new single inhaler product containing both budesonide and formoterol in adult asthma. European Respiratory Journal 2000;16(Suppl 31):455s Abstract P3198.

Zetterström O, Buhl R, Mellem H, Perpiñá M, Hedman J, O'Neill S, et al.The new single inhaler product containing both budesonide/formoterol improves asthma control in adults. European Respiratory Journal 2000;16(Supp 31): 455s Abstract P3199.

\section{References to studies excluded from this review}

\section{Ankerst 2003 \{published data only\}}

Ankerst J, Persson G, Weibull E. Tolerability of a high dose of budesonide/formoterol in a single inhaler in patients with asthma. Pulmonary Pharmacology \& Therapeutics 2003; Vol. 16, issue 3:147-51. 
AstraZeneca 2005 \{published data only\}

AstraZeneca. Efficacy \& safety of Symbicort Turbuhaler 160/4.5 $\mu \mathrm{g}$ twice daily \& Pulmicort Turbuhaler $200 \mu \mathrm{g}$ twice daily + Theolong tablet $200 \mathrm{mg}$ twice daily in Japanese asthmatic patients. clinicaltrials.gov 2005.

AstraZeneca 2005a \{published data only\}

AstraZeneca. SHARE - symbicort and health economics in a real life evaluation. clinicaltrials.gov 2005.

AstraZeneca 2005b \{published data only\} AstraZeneca. SOLO-symbicort in the treatment of persistent asthma in adolescents $\&$ adults. clinicaltrials.gov 2005.

AstraZeneca 2005c \{published data only\}

AstraZeneca. STYLE - symbicort single inhaler therapy vs. conventional therapy in treatment of persistent asthma. clinicaltrials.gov 2005.

AstraZeneca 2005d \{published data only\} AstraZeneca. SYMPHONIE -a comparison of symbicort single inhaler and conventional best practice for the treatment of persistent asthma in adolescents and adults. clinicaltrials.gov 2005.

AstraZeneca 2006 \{published data only\} AstraZeneca. A comparison of the control of asthma inflammation provided by Symbicort turbuhaler 160/ $4.5 \mathrm{mcg} /$ inhalation bid plus as-needed versus symbicort turbuhaler 320/9 ug/inhalation bid plus pulmicort turbuhaler $400 \mathrm{mcg} / \mathrm{dose}$ bid plus terbutaline turbuhaler $0.4 \mathrm{mg}$ /inhalation as-needed. clinicaltrials.gov 2006.

AstraZeneca 2006a \{published data only\}

AstraZeneca. MONO: Symbicort single inhaler therapy and conventional best standard treatment for the treatment of persistent asthma in adolescents and adults. clinicaltrials.gov 2006.

AstraZeneca 2006b \{published data only\}

AstraZeneca. SALTO - symbicort single inhaler therapy use in adolescent adults and adults with persistent asthma. clinicaltrials.gov 2006.

Balanag 2006 \{published data only\} Balanag VM, Yunus F, Yang PC, Jorup C. Efficacy and safety of budesonide/formoterol compared with salbutamol in the treatment of acute asthma. Pulmonary Pharmacology \& Therapeutics 2006; Vol. 19, issue 2:139-47.

Bateman 2003 \{published data only\}

Bateman ED, Bantje TA, Gomes MJ, Toumbis MG,

Huber RM, Naya I, et al.Combination therapy with single inhaler budesonide/formoterol compared with high dose of fluticasone propionate alone in patients with moderate persistent asthma. American Journal of Respiratory Medicine 2003; Vol. 2, issue 3:275-81.

Bateman 2006 \{published data only\}

Bateman ED, Fairall L, Lombardi DM, English R. Budenoside/formoterol and formoterol provide similar rapid relief in patients with acute asthma showing refractoriness to salbutamol. Respiratory Research. 2006; Vol. 7:13.
Bouros 1999 \{published data only\}

Bouros D, Bachlitzanakis N, Kottakis J, Pfister P, Polychronopoulos V, Papadakis E, et al.Formoterol and beclomethasone versus higher dose beclomethasone as maintenance therapy in adult asthma. European Respiratory Journal 1999; Vol. 14, issue 3:627-32.

Buhl 2004 \{published data only\}

Buhl R, Kardos P, Richter K, Meyer-Sabellek W, Bruggenjurgen $\mathrm{B}$, Willich $\mathrm{SN}$, et al.The effect of adjustable dosing with budesonide/formoterol on health-related quality of life and asthma control compared with fixed dosing. Current Medical Research \& Opinion 2004; Vol. 20 , issue $8: 1209-20$.

\section{Burgess 1998 \{published data only\}}

Burgess C, Ayson M, Rajasingham S, Crane J, Della Cioppa G, Till MD. The extrapulmonary effects of increasing doses of formoterol in patients with asthma. European Journal of Clinical Pharmacology 1998; Vol. 54, issue 2:141-7.

Canonica 2004 \{published data only\} Canonica GW, Castellani P, Cazzola M, Fabbri LM, Fogliani V, Mangrella M, et al.Adjustable maintenance dosing with budesonide/formoterol in a single inhaler provides effective asthma symptom control at a lower dose than fixed maintenance dosing. Pulmonary Pharmacology \& Therapeutics 2004; Vol. 17, issue 4:239-47.

Ceylan 2004 \{published data only\} Ceylan E, Mehmet G, Sahin A. Addition of formoterol or montelukast to low-dose budesonide: An efficacy comparison in short- and long-term asthma control. Respiration 2004; Vol. 71, issue 6:594-601.

Dhillon 2006 \{published data only\}

Dhillon S, Keating GM. Beclometasone dipropionate/ formoterol: In an HFA-propelled pressurised metered-dose inhaler. Drugs 2006; Vol. 66, issue 11:1475-83.

FitzGerald 1999 \{published data only\} FitzGerald JM, Chapman KR, Della Cioppa G, Stubbing D, Fairbarn MS, Till MD, et al.Sustained bronchoprotection, bronchodilatation, and symptom control during regular formoterol use in asthma of moderate or greater severity. Journal of Allergy \& Clinical Immunology 1999; Vol. 103, issue $3 \mathrm{I}: 427-35$.

FitzGerald 2003 \{published data only\} FitzGerald JM, Sears MR, Boulet LP, Becker AB, McIvor AR, Ernst P, et al.Adjustable maintenance dosing with budesonide/formoterol reduces asthma exacerbations compared with traditional fixed dosing: A five-month multicentre Canadian study. Canadian Respiratory Journal 2003; Vol. 10, issue 8:427-34.

Haahtela 2006 \{published data only\}

Haahtela T, Tamminen K, Malmberg LP, Zetterstrom O, Karjalainen J, Yla-Outinen H, et al.Formoterol as needed with or without budesonide in patients with intermittent asthma and raised NO levels in exhaled air: A SOMA study. European Respiratory Journal 2006; Vol. 28, issue 4: $748-55$. 
Ind 2004 \{published data only\}

Ind PW, Haughney J, Price D, Rosen JP, Kennelly J. Adjustable and fixed dosing with budesonide/formoterol via a single inhaler in asthma patients: The ASSURE study. Respiratory Medicine 2004; Vol. 98, issue 5:464-75.

\section{Kozlik-Feldmann 1996 \{published data only\}} Kozlik-Feldmann R, von Berg A, Berdel D, Reinhardt D. Long-term effects of formoterol and salbutamol on bronchial hyperreactivity and beta-adrenoceptor density on lymphocytes in children with bronchial asthma. European Journal of Medical Research 1996; Vol. 1, issue 10:465-70.

Lalloo 2003 \{published data only\}

Lalloo UG, Malolepszy J, Kozma D, Krofta K, Ankerst J, Johansen $\mathrm{B}$, et al.Budesonide and formoterol in a single inhaler improves asthma control compared with increasing the dose of corticosteroid in adults with mild-to-moderate asthma. Chest 2003; Vol. 123, issue 5:1480-7.

Leuppi 2003 \{published data only\}

Leuppi FD, Salzberg M, Meyer L, Bucher SE, Nief $\mathrm{M}$, Brutsche $\mathrm{MH}$, et al.An individualized, adjustable maintenance regimen of budesonide/formoterol provides effective asthma symptom control at a lower overall dose than fixed dosing. Swiss Medical Weekly 2003; Vol. 133, issue 21-22:302-9.

\section{Lotvall \{published data only\}}

Lotvall J, Langley S, Woodcock A. Inhaled steroid/longacting beta 2 agonist combination products provide 24 hours improvement in lung function in adult asthmatic patients. Respiratory Research. Vol. 7, 2006. Article Number: 110. Date of Publication: 18 AUG 2006.

Lundborg 2006 \{published data only\} Lundborg M, Wille S, Bjermer L, Tilling B, Lundgren $\mathrm{M}$, Telg G, et al.Maintenance plus reliever budesonide/ formoterol compared with a higher maintenance dose of budesonide/formoterol plus formoterol as reliever in asthma: An efficacy and cost-effectiveness study. Current Medical Research \& Opinion 2006; Vol. 22, issue 5: $809-21$.

\section{Mitchell 2003 \{published data only\}}

Mitchell C, Jenkins C, Scicchitano R, Rubinfeld A, Kottakis J. Formoterol (Foradil) and medium-high doses of inhaled corticosteroids are more effective than high doses of corticosteroids in moderate-to-severe asthma. Pulmonary Pharmacology \& Therapeutics 2003; Vol. 16, issue 5: 299-306.

Molimard 2001 \{published data only\}

Molimard M, Bourcereau J, Le Gros V, Bourdeix I, Leynadier F, Duroux P, et al.Comparison between formoterol 12 microg b.i.d. and on-demand salbutamol in moderate persistent asthma. Respiratory Medicine 2001; Vol. 95, issue 1:64-70.

Novartis 2005 \{published data only\}

Novartis. A 12-month multicenter, randomized, doubleblind, double-dummy trial to examine the long-term tolerability of fomoterol $10 \mu \mathrm{g}$ via the multiple dose dry powder inhaler (MDDPI), both as twice daily maintenance therapy and as on-demand use in addition to maintenance in patients with persistent asthma. http:// pharma.us.novartis.com/ 2005.

O'Byrne 2005 \{published data only\}

O'Byrne PM, Bisgaard H, Godard PP, Pistolesi M, Palmqvist $\mathrm{M}$, Zhu Y, et al.Budesonide/formoterol combination therapy as both maintenance and reliever medication in asthma. [see comment]. American Journal of Respiratory \& Critical Care Medicine 2005; Vol. 171, issue 2:129-36.

Overbeek 2005 \{published data only\}

Overbeek SE, Mulder PG, Baelemans SM, et al.Formoterol added to low dose budesonide has no additional antiinflammatory effect in asthmatic patients. Chest 2005;128: 1121-27.

Papi 2007 \{published data only\}

Papi A, Paggiaro PL, Nicolini G, Vignola AM, Fabbri LM, Zarkovic J, et al.Beclomethasone/formoterol versus budesonide/formoterol combination therapy in asthma. European Respiratory Journal 2007; Vol. 29, issue 4:682-9.

Pauwels 2003 \{published data only\} Pauwels RA, Sears MR, Campbell M, Villasante C, Huang $\mathrm{S}$, Lindh $\mathrm{A}$, et al.Formoterol as relief medication in asthma: a worldwide safety and effectiveness trial. European Respiratory Journal 2003; Vol. 22, issue 5:787-94.

Pleskow 2003 \{published data only\}

Pleskow W, LaForce CF, Yegen U, Matos D, Della Cioppa G. Formoterol delivered via the dry powder Aerolizer inhaler versus albuterol MDI and placebo in mild-to-moderate asthma: a randomized, double-blind, double-dummy trial. J Asthma 2003; Vol. 40, issue 5:505-14.

Pohl 2006 \{published data only\}

Pohl WR, Vetter N, Zwick H, Hrubos W. Adjustable maintenance dosing with budesonide/formoterol or budesonide: Double-blind study. Respiratory Medicine 2006; Vol. 100, issue 3:551-60.

Rabe 2006 \{published data only\}

Rabe KF, Pizzichini E, Stallberg B, Romero S, Balanzat AM, Atienza $T$, et al.Budisonide/formoterol in a single inhaler for maintenance and relief in mild-to-moderate asthma: A randomized, double-blind trial. Chest 2006; Vol. 129, issue 2:246-56.

Rosenhall 2002 \{published data only\}

Rosenhall L, Heinig JH, Lindqvist A, Leegaard J, Stahl E, Bergqvist PB. Budesonide/formoterol (Symbicort) is well tolerated and effective in patients with moderate persistent asthma. International Journal of Clinical Practice. 2002; Vol. 56, issue 6:427-33.

Rosenhall 2003 \{published data only\} Rosenhall L, Borg S, Andersson HF, Ericsson K. Budesonide/formoterol in a single inhaler (Symbicort) reduces healthcare costs compared with separate inhalers in the treatment of asthma over 12 months. International Journal of Clinical Practice 2003; Vol. 57, issue 8:662-7.

Rosenhall 2003a \{published data only\} Rosenhall L, Elvstrand A, Tilling B, Vinge I, Jemsby P, Stahl E, et al.One-year safety and efficacy of budesonide/ 
formoterol in a single inhaler (Symbicort Turbuhaler) for the treatment of asthma. Respiratory Medicine 2003; Vol. 97 , issue 6:702-8.

\section{Scicchitano $2004\{$ published data only\}}

Scicchitano R, Aalbers R, Ukena D, Manjra A, Fouquert L, Centann S, et al.Efficacy and safety of budesonide/ formoterol single inhaler therapy versus a higher dose of budesonide in moderate to severe asthma. Current Medical Research \& Opinion 2004; Vol. 20, issue 9:1403-18.

\section{Stelmach 2007 \{published data only\}}

Stelmach I, Grzelewski T, Bobrowska-Korzeniowska M, Stelmach P, Kuna P. A randomized, double-blind trial of the effect of anti-asthma treatment on lung function in children with asthma. Pulm Pharmacol Ther. 2006/10/19 2007; Vol. 20, issue 6:691-700. [1094-5539: (Print)]

van der Molen 1997 \{published data only\} van der Molen T, Postma DS, Turner MO, Jong BM, Malo JL, Chapman K, et al.Effects of the long acting beta agonist formoterol on asthma control in asthmatic patients using inhaled corticosteroids. The Netherlands and Canadian Formoterol Study Investigators. Thorax 1997; Vol. 52, issue 6:535-9.

\section{Villa, 2002 \{published data only\}}

Villa, Kuna, Egner, B. A 6-month comparison of the safety profiles of formoterol (Oxis $\left.{ }^{\circledR}\right)$ turbuhaler ${ }^{\circledR}$ as needed and terbutaline (Bricanyl $\left.{ }^{\circledR}\right)$ turbuhaler ${ }^{\circledR}$ as needed in asthmatic children on anti-inflammaotry medication [abstract]. American Journal of Respiratory and Critical Care Medicine 2002; Vol. 165, issue 8 Suppl:A746.

Von Berg 2003 \{published data only\}

Von Berg A, Papageorgiou Saxoni F, Wille S, Carrillo T, Kattamis C, Helms PJ. Efficacy and tolerability of formoterol turbuhaler in children. International Journal of Clinical Practice 2003; Vol. 57, issue 10:852-6.

Worth 2005 \{published data only\}

Worth H. DESOLO - SiT Peri-Launch: a comparison of symbicort single inhaler therapy and conventional best practice for the treatment of persistent asthma in adults. clinicaltrials.gov 2005.

Zetterstrom 2001a \{published data only\}

Zetterstrom O, Buhl R, Mellem H. Efficacy and safety of symbicort ${ }^{\circledR}$ budesonide and formoterol in a single inhaler in adults with asthma. Annual Thoracic Society 97th International Conference; San Francisco CA ,May 18-23 2001.

\section{Zetterström 2000 \{published data only\}}

Zetterström O, Buhl R, Mellem H, Perpiñá M, Hedman J, O'Neill S, et al.Efficacy and safety of a new single inhaler product containing both budesonide and formoterol in adult asthma. European Respiratory Journal 2000; Vol. 16, issue Suppl 31:455s Abstract P3198.

\section{Additional references}

\section{Altman 2003}

Altman DG, Bland JM. Statistics Notes: Interaction revisited: the difference between two estimates. BMJ 2003; 326(7382):219.

\section{Anderson 2006}

Anderson GP. Current issues with beta(2)-adrenoceptor agonists - Pharmacology and molecular and cellular mechanisms. Clinical Reviews in Allergy \& Immunology 2006; Vol. 31, issue 2-3:119-30.

\section{Arnold 1985}

Arnold JMO, Oconnor PC, Riddell JG, Harron DWG, Shanks RG, McDevitt DG. Effects of the beta-2adrenoceptor antagonist ici-118,551 on exercise tachycardia and isoprenaline-induced beta-adrenoceptor responses in man. British Journal of Clinical Pharmacology 1985; Vol. 19 , issue 5:619-30.

\section{Barnes 1993}

Barnes PJ. Beta-adrenoceptors on smooth-muscle, nerves and inflammatory cells. Life Sciences 1993; Vol. 52, issue 26:2101-9.

\section{Barnes 1995}

Barnes PJ. Beta-adrenergic receptors and their regulation. American Journal of Respiratory and Critical Care Medicine 1995; Vol. 152, issue 3:838-60.

\section{Beach 1992}

Beach JR, Young CL, Stenton SC, Avery AJ, Walters EH, Hendrick DJ. A comparison of the speeds of action of salmeterol and salbutamol in reversing methacholineinduced bronchoconstriction. Pulm-Pharmacol 1992;5(2): 133-5.

\section{Bennett 1994}

Bennett JA, Smyth ET, Pavord ID, Wilding PJ, Tattersfield AE. Systemic effects of salbutamol and salmeterol in patients with asthma. Thorax 1994; Vol. 49, issue 8:771-4.

\section{Brown 1983}

Brown MJ, Brown DC, Murphy MB. Hypokalemia from beta-2-receptor stimulation by circulating epinephrine. New England Journal of Medicine 1983; Vol. 309, issue 23:1414-9.

\section{Burgess 1991}

Burgess CD, Windom HH, Pearce N, Marshall S, Beasley R, Siebers RWL, et al.Lack of evidence for beta-2 receptor selectivity - a study of metaproterenol, fenoterol, isoproterenol, and epinephrine in patients with asthma. American Review of Respiratory Disease 1991; Vol. 143, issue 2:444-6.

\section{Burggraaf 2001}

Burggraaf J, Westendorp RGJ, in't Veen J, Schoemaker RC, Sterk PJ, Cohen AF, et al.Cardiovascular side effects of inhaled salbutamol in hypoxic asthmatic patients. Thorax 2001; Vol. 56, issue 7:567-9.

\section{Cates 2008}

Cates CJ, Cates MJ. Regular treatment with salmeterol for chronic asthma: serious adverse events (Cochrane Review). Cochrane Database of Systematic Reviews 2008, Issue 3. [DOI: 10.1002/14651858.CD006363.pub2] 


\section{Cates 2008a}

Cates Christopher J, Cates Matthew J, Lasserson Toby J. Regular treatment with formoterol for chronic asthma: serious adverse events. Cochrane Database of Systematic Reviews 2008, Issue 4. [DOI: 10.1002/ 14651858.CD006923.pub2]

\section{Cockcroft 1993}

Cockcroft DW, McParland CP, Britto SA, Swystun VA, Rutherford BC. Regular inhaled salbutamol and airway responsiveness to allergen. Lancet 1993; Vol. 342, issue 8875:833-7.

\section{Collins 1969}

Collins JM, McDevitt DG, Shanks RG, Swanton JG. Cardio-toxicity of isoprenaline during hypoxia. British Journal of Pharmacology 1969; Vol. 36, issue 1:35-\&.

\section{Crane 1989}

Crane J, Pearce N, Flatt A, Burgess C, Jackson R, Kwong $\mathrm{T}$, et al.Prescribed fenoterol and death from asthma in New Zealand, 1981-83 - case-control study. Lancet 1989; Vol. 1 , issue 8644:917-22.

\section{Ducharme 2006}

Ducharme FM, Lasserson TJ, Cates CJ. Long-acting beta2 agonists versus anti-leukotrienes as add-on therapy to inhaled corticosteroids for chronic asthma (Cochrane Review). Cochrane Database of Systematic Reviews 2006, Issue 4. [DOI: 10.1002/14651858.CD003137.pub3]

\section{Giembycz 2006}

Giembycz MA, Newton R. Beyond the dogma: novel B2adrenoceptor signalling in the airways. European Respiratory Journal 2006;27(6):1286-1306.

\section{Grainger 1991}

Grainger J, Woodman K, Pearce N, Crane J, Burgess C, Keane A, et al.Prescribed fenoterol and death from asthma in new-zealand, 1981-7 - a further case-control study. Thorax 1991; Vol. 46, issue 2:105-11.

Greenstone 2005

Greenstone IR, Ni Chroinin M, Masse V, Danish A, Magdalinos H, Zhang X, et al.Combination of inhaled long-acting beta2-agonists and inhaled steroids versus higher dose of inhaled steroids in children and adults with persistent asthma (Cochrane Review). Cochrane Database of Systematic Reviews 2005, Issue 4. [DOI: 10.1002/ 14651858.CD005533]

Guhan 2000

Guhan AR, Cooper S, Oborne J, Lewis S, Bennett J, Tattersfield AE. Systemic effects of formoterol and salmeterol: a dose-response comparison in healthy subjects. Thorax 2000; Vol. 55, issue 8:650-6.

\section{Hall 1989}

Hall JA, Petch MC, Brown MJ. Intracoronary injections of salbutamol demonstrate the presence of functional beta-2adrenoceptors in the human-heart. Circulation Research 1989; Vol. 65, issue 3:546-53.

\section{Hanania 2002}

Hanania NA, Sharfkhaneh A, Barber R, Dickey BF. betaagonist intrinsic efficacy - Measurement and clinical significance. American Journal of Respiratory and Critical Care Medicine 2002; Vol. 165, issue 10:1353-8.

\section{Hanania 2007}

Hanania NA, Moore RH, Zimmerman JL, Miller CT, Bag $\mathrm{R}$, Sharafkhaneh A, et al.The role of intrinsic efficacy in determining response to beta(2)-agonist in acute severe asthma. Respiratory Medicine 2007; Vol. 101, issue 5: 1007-14.

\section{Hancox 1999}

Hancox RJ, Aldridge RE, Cowan JO, Flannery EM, Herbison GP, McLachlan CR, et al.Tolerance to betaagonists during acute bronchoconstriction. European Respiratory Journal 1999; Vol. 14, issue 2:283-7.

\section{Hancox 2006}

Hancox RJ. Interactions between corticosteroids and beta2agonists. Clinical Reviews in Allergy \& Immunology 2006; Vol. 31, issue 2-3:231-46. [: (Print)]

\section{Haney 2006}

Haney S, Hancox RJ. Recovery from bronchoconstriction and bronchodilator tolerance. Clinical Reviews in Allergy \& Immunology 2006; Vol. 31, issue 2-3:181-96.

\section{Harvey 1982}

Harvey JE, Tattersfield AE. Airway response to salbutamol effect of regular salbutamol inhalations in normal, atopic, and asthmatic subjects. Thorax 1982; Vol. 37, issue 4: $280-7$.

\section{ICHE2a 1995}

Expert Working Group (Efficacy) of theInternational Conference on Harmonisation of Technical Requirements for Registrationof Pharmaceuticals for Human Use (ICH). Clinical safety data management: Definitions and standards for expedited reporting. http://www.fda.gov/cder/guidance/ iche2a.pdf 1995.

\section{Jaeschke 2008}

Jaeschke R, O'Byrne PM, Parameswaran N, et al.The safety of formoterol among patients with asthma using inhaled corticosteroids. Systematic review and meta-analysis.. Polskie Archiwum Medycyny Wewnetrznej In press.

\section{Jaeschke 2008a}

Jaeschke R, O’Byrne PM, Mejza F, Nair P, Lesniak W, Brozek J, et al.The Safety of Long-Acting Beta-Agonists among Patients with Asthma Using Inhaled Corticosteroids: Systematic Review and Meta-analysis. Am. J. Respir. Crit. Care Med. 2008; Vol. 178, issue 10:1009-16.

Jones 2001

Jones SL, Cowan JO, Flannery EM, Hancox RJ, Herbison GP, Taylor DR. Reversing acute bronchoconstriction in asthma: the effect of bronchodilator tolerance after treatment with formoterol. European Respiratory Journal 2001; Vol. 17, issue 3:368-73.

Lee 2003

Lee DKC, Jackson CM, Currie GP, Cockburn WJ, Lipworth BJ. Comparison of combination inhalers vs inhaled corticosteroids alone in moderate persistent asthma. British Journal of Clinical Pharmacology 2003; Vol. 56, issue 5:494-500. 
Lipworth 1989

Lipworth BJ, Struthers AD, McDevitt DG. Tachyphylaxis to systemic but not to airway responses during prolonged therapy with high-dose inhaled salbutamol in asthmatics. American Review of Respiratory Disease 1989; Vol. 140, issue 3:586-92.

\section{Lipworth 1992}

Lipworth BJ, McDevitt DG. Inhaled beta-2-adrenoceptor agonists in asthma - help or hindrance. British Journal of Clinical Pharmacology 1992; Vol. 33, issue 2:129-38.

\section{Lipworth 1997}

Lipworth BJ. Airway sub-sensitivity with long-acting beta 2-agonists: Is there cause for concern?. Drug Safety 1997;16 (5):295-308

\section{Lipworth 2000}

Lipworth BJ, Aziz I. Bronchodilator response to albuterol after regular formoterol and effects of acute corticosteroid administration. Chest 2000; Vol. 117, issue 1:156-62.

\section{McDevitt 1974}

McDevitt DG, Shanks RG, Swanton JG. Further observations on cardiotoxicity of isoprenaline during hypoxia. British Journal of Pharmacology 1974; Vol. 50, issue 3:335-44.

\section{Morrison 1993}

Morrison KJ, Gao Y, Vanhoutte PM. Beta-adrenoceptors and the epithelial layer in airways. Life Sciences 1993; Vol. 52 , issue 26:2123-30.

\section{Nelson 1977}

Nelson HS, Raine D, Doner HC, Posey WC. Subsensitivity to bronchodilator action of albuterol produced by chronic administration. American Review of Respiratory Disease 1977; Vol. 116, issue 5:871-8.

\section{Ni Chroinin 2004}

Ni Chroinin M, Greenstone IR, Ducharme FM. Addition of inhaled long-acting beta2-agonists to inhaled steroids as first line therapy for persistent asthma in steroidnaive adults (Cochrane Review). Cochrane Database of Systematic Reviews 2004, Issue 4. [DOI: DOI: 10.1002/ 14651858.CD005307]

\section{Ni Chroinin 2005}

Ni Chroinin M, Greenstone IR, Danish A, Magdolinos $\mathrm{H}$, Masse V, Zhang X, et al.Long-acting beta2-agonists versus placebo in addition to inhaled corticosteroids in children and adults with chronic asthma. Cochrane Database of Systematic Reviews 2005, Issue 4. [DOI: 10.1002/ 14651858.CD005535; : CD005535]

\section{Novartis 2008}

Novartis. Foradil (formoterol fumarate inhalation powder). FDA Advisory Committee Meetign for the safety of long-acting beta 2 -agonists for the treatment of asthma in adults and children (December 10-11, 2008). http:// www.fda.gov/ohrms/dockets/ac/08/briefing/2008-4398b102-Novartis.pdf Accessed January 8th 2009.

\section{Palmqvist 1999}

Palmqvist M, Ibsen T, Mellen A, Lotvall J. Comparison of the relative efficacy of formoterol and salmeterol in asthmatic patients. American Journal of Respiratory and Critical Care Medicine 1999; Vol. 160, issue 1:244-9.

\section{Pearce 1990}

Pearce N, Grainger J, Atkinson M, Crane J, Burgess C, Culling C, et al.Case-control study of prescribed fenoterol and death from asthma in new-zealand, 1977-81. Thorax 1990; Vol. 45, issue 3:170-5.

\section{Pearce 2007}

Pearce N. Adverse reactions: the Fenoterol story. 1. Auckland: Auckland University Press, 2007:215. [: 9781869403744]

\section{Sears 1986}

Sears M, Rea H, Rothwell R, O’Donnell T, Holst P, Gillies A, et al.Asthma mortality: comparison between New Zealand and England. British Medical Journal 1986;293 (6558):1342-5.

\section{Sears 1990}

Sears MR, Taylor DR, Print CG, Lake DC, Li QQ, Flannery EM, et al.Regular inhaled beta-agonist treatment in bronchial-asthma. Lancet 1990; Vol. 336, issue 8728: 1391-6.

Sears 2008

Sears MR, Ottosson A, Radner F, Suissa S. Long-acting $\{$ beta\}-agonists: A review of formoterol safety data from asthma clinical trials. European Respiratory Journal 2008: 09031936.00145006

\section{SMART 2006}

Nelson HS, Weiss ST, Bleecker ER, Yancey SW, Dorinsky PM, the SMART Study Group. The Salmeterol Multicenter Asthma Research Trial: A Comparison of Usual Pharmacotherapy for Asthma or Usual Pharmacotherapy Plus Salmeterol. Chest 2006;129:15-26.

\section{SNS 1993}

Castle W, Fuller R, Hall J. Serevent nationwide surveillance study:Comparison of salmeterol with salbutamol in asthmatic patients who require regular bronchodilator treatment. British Medical Journal 1993;306:1034-7.

\section{Speizer 1968}

Speizer FE, Doll R, Heaf P. Observations on recent increase in mortality from asthma. British Medical Journal 1968; Vol. 1, issue 5588:335-\&.

\section{Sweeting 2004} Sweeting MJ, Sutton AJ, Lambert PC. What to add to nothing? Use and avoidance of continuity corrections in meta-analysis of sparse data. Stat Med. 2004/04/30 2004; Vol. 23, issue 9:1351-75. [0277-6715: (Print)]

van der Woude 2001

van der Woude HJ, Winter TH, Aalbers R. Decreased bronchodilating effect of salbutamol in relieving methacholine induced moderate to severe bronchoconstriction during high dose treatment with long acting beta(2) agonists. Thorax 2001; Vol. 56, issue 7: $529-35$.

vanNoord 1996

vanNoord JA, Smeets JJ, Raaijmakers JAM, Bommer AM, Maesen FPV. Salmeterol versus formoterol in patients with 
moderately severe asthma: Onset and duration of action. European Respiratory Journal 1996; Vol. 9, issue 8:1684-8.

\section{Walters 2002}

Walters EH, Walters JAE, Gibson PW. Regular treatment with long acting beta agonists versus daily regular treatment with short acting beta agonists in adults and children with stable asthma (Cochrane Review). Cochrane Database of Systematic Reviews 2002, Issue 3. [DOI: 10.1002/ 14651858.CD003901]

\section{Walters 2007}

Walters EH, Gibson PG, Lasserson TJ, Walters JAE. Longacting beta2-agonists for stable chronic asthma (Cochrane Review). Cochrane Database of Systematic Reviews 2007, Issue 1. [DOI: DOI: 10.1002/14651858.CD001385.pub2]

\section{Weber 1982}

Weber RW, Smith JA, Nelson HS. Aerosolized terbutaline in asthmatics - development of subsensitivity with long- term administration. Journal of Allergy and Clinical Immunology 1982; Vol. 70, issue 6:417-22.

\section{Wilson 1981}

Wilson JD, Sutherland DC, Thomas AC. Has the change to beta-agonists combined with oral theophylline increased cases of fatal asthma. Lancet 1981; Vol. 1, issue 8232: $1235-7$.

\section{Wong 1990}

Wong CS, Pavord ID, Williams J, Britton JR, Tattersfield AE. Bronchodilator, cardiovascular, and hypokalemic effects of fenoterol, salbutamol, and terbutaline in asthma. Lancet 1990; Vol. 336, issue 8728:1396-9.

Yates 1996

Yates DH, Kharitonov SA, Barnes PJ. An inhaled glucocorticoid does not prevent tolerance to the bronchoprotective effect of a long-acting inhaled beta(2)agonist. American Journal of Respiratory and Critical Care Medicine 1996; Vol. 154, issue 6:1603-7.

* Indicates the major publication for the study 
CHARACTERISTICS OF STUDIES

Characteristics of included studies [ordered by study ID]

Buhl 2003

Methods

Study Design: A randomised, double-blind, double-dummy, active-controlled, Multicentre, parallel-group study over 12 weeks from October 1999 to June 2000 at 56 centres in 9 countries. (Argentina (5), Belgium (5), the Czech Republic (14), Germany (6), Mexico (4), Russia (6), Spain (5), the Netherlands (7) and United Kingdom (4)) Run-in 2 weeks (budesonide 200 mcg twice daily)

Population: 523 adults $(18-78)$ years with moderate persistent asthma.
Baseline Characteristics: Mean age 44 years. $\mathrm{FEV}_{1} 77 \%$ predicted. Concomitant in-
haled corticosteroids used by $100 \%$ of participants $(400-1000 \mathrm{mcg} /$ day) and patients
not fully controlled on this dose
Inclusion Criteria:Out-patients aged 18 years and older with perennial asthma (ATS)
with a minimum duration of 6 months. Used any inhaled corticosteroid at a constant
daily dose of $400-1000 \mu \mathrm{g}$ for at least 30 days before entry and still had sub-optimal
asthma control. $\mathrm{FEV}_{1} \%$ predicted between $60 \%$ to $90 \%$, bronchodilator reversibility
by an increase of at least $12 \%$ in FEV $\mathrm{F}_{1}$ over baseline at 15 minutes after inhalation of a
short-acting beta2-agonist
Exclusion Criteria: Use of oral, parental or rectal GCS within 30 days prior to visit
1, seasonal asthma, significant respiratory infection within 30 days of visit 1, severe
cardiovascular disorder or any other significant disease or disorder, pregnant or planning
a pregnancy, breast-feeding, not using acceptable contraceptives, not surgically sterile,
hypersensitivity to study drugs, tobacco smokers or previous smokers if greater than 10
pack-years

Interventions

1. Budesonide/Formoterol $320 / 9 \mu$ g daily

2. Budesonide/Formoterol $160 / 4.5 \mu$ twice daily

3. Budesonide $400 \mu \mathrm{g}$ daily (equivalent daily dose of budesonide)

Delivery was DPI

\begin{tabular}{ll} 
Outcomes & $\begin{array}{l}\text { The primary efficacy variable was morning peak expiratory flow (am PEF, L/min) } \\
\text { Paper reports five SAEs: one in the once daily BDF group and two each in the other } \\
\text { groups. They included one death due to cardiac arrest and four other events. (No details } \\
\text { given by treatment group in paper or on web report) } \\
\text { Jaeschke } 2008 \text { reports one death on combined treatment and two participants with } \\
\text { non-fatal SAE on combined treatment and two on budesonide. One SAE on BDF was } \\
\text { asthma-related }\end{array}$ \\
\hline Notes & Sponsored by AstraZeneca
\end{tabular}

Risk of bias

\begin{tabular}{lll}
\hline Item & Authors' judgement & Description \\
\hline Adequate sequence generation? & Unclear & Not reported
\end{tabular}


Buhl 2003 (Continued)

\begin{tabular}{l|ll}
\hline Allocation concealment? & Unclear & Not reported \\
\hline $\begin{array}{l}\text { Blinding? } \\
\text { All outcomes }\end{array}$ & Yes & Double-blind \\
\hline $\begin{array}{l}\text { Incomplete outcome data addressed? } \\
\text { All outcomes }\end{array}$ & Yes & $480 / 523(92 \%)$ completed the study \\
\hline Free of selective reporting? & Yes & $\begin{array}{l}\text { SAE data not attributable to treatment } \\
\text { groups in paper but obtained from Jaeschke } \\
\text { 2008 }\end{array}$ \\
\hline
\end{tabular}

\section{Chuchalin 2002}

\begin{tabular}{|c|c|}
\hline Methods & $\begin{array}{l}\text { Study Design: A randomised, double-blind, parallel-group study over } 12 \text { weeks in } \\
\text { Russia. Run-in } 2 \text { weeks }\end{array}$ \\
\hline Participants & $\begin{array}{l}\text { Population: } 338 \text { adults (18-66) years with mild to moderate asthma. } \\
\text { Baseline Characteristics: Mean age } 45 \text { years. } \mathrm{FEV}_{1} \text { unknown } \% \text { predicted. Concomitant } \\
\text { inhaled corticosteroids used by } 0 \% \text { of participants. } \\
\text { Inclusion Criteria:Diagnosed at least } 6 \text { months. } \mathrm{FEV}_{1} \% \text { predicted between } 50 \% \text { and } \\
85 \% \text {, bronchodilator reversibility at least } 15 \% \text { in } \mathrm{FEV}_{1} \text { over baseline after inhalation of } \\
\text { terbutaline. Female patients to be postmenopausal, surgically sterile or using medically } \\
\text { approved contraceptive measures. } \\
\text { Exclusion Criteria: smoking history of greater than } 10 \text { pack-years, current or recent users } \\
\text { of inhaled, oral or parenteral corticosteroids, oral leukotriene antagonists, nedocromil } \\
\text { sodium or sodium cromoglycate, beta-blockers (including eye drops) }\end{array}$ \\
\hline Interventions & $\begin{array}{l}\text { 1. Budesonide and Formoterol } 200 \text { and } 9 \mu \mathrm{g} \mathrm{BD} \\
\text { 2. Budesonide } 200 \mu \mathrm{g} \text { BD } \\
\text { Delivery was DPI }\end{array}$ \\
\hline
\end{tabular}

Outcomes

The primary efficacy variable was the change in peak expiratory flow (PEF) in the morning before any study medication was taken

Paper reports no deaths and two serious adverse events (aggravated asthma and hypertension) that required hospitalisation in the budesonide only group

Notes Supported by AstraZeneca

\section{Risk of bias}

\begin{tabular}{l|l|l}
\hline Item & Authors' judgement & Description \\
\hline Adequate sequence generation? & Unclear & Not reported \\
\hline Allocation concealment? & Unclear & $\begin{array}{l}\text { "Allocated a randomised number (identi- } \\
\text { fying which of the three treatments they } \\
\text { would receive) in consecutive order, per }\end{array}$
\end{tabular}


Chuchalin 2002 (Continued)

centre, at the second visit”

\begin{tabular}{l|l|l}
\hline $\begin{array}{l}\text { Blinding? } \\
\text { All outcomes }\end{array}$ & Yes & centre, at the second visit” \\
\hline $\begin{array}{l}\text { Incomplete outcome data addressed? } \\
\text { All outcomes }\end{array}$ & Yes & $316 / 338(93 \%)$ completed the study. \\
\hline \begin{tabular}{l} 
Free of selective reporting? \\
\hline
\end{tabular} & Yes & SAE data reported in the paper \\
\hline
\end{tabular}

Corren 2007

Methods

Randomized, double-blind, double-dummy, multicenter, placebo-controlled study over 12 weeks at 56 US centres from July 2002 to September 2003. Run-in 7-21 days in which usual asthma therapy was withdrawn

Participants
asthma. 123 randomised to BDF and 121 to Budesonide. The web report also includes a
further 13 children in these treatment groups aged $6-11$ years, but they are not separately
analysed
Baseline Characteristics: Mean age 36 years. FEV $175 \%$ predicted. Concomitant in-
haled corticosteroids used by $100 \%$ of participants at baseline but withdrawn for the
formoterol and placebo arms of this study
Inclusion Criteria: Mild to moderate persistent asthma for at least 6 months, treated
with inhaled corticosteroids for at least 4 weeks before screening, FEV $V_{1}$ between $60 \%$
and $90 \%$ predicted on ICS at screening and between $50 \%$ and $85 \%$ predicted after
discontinuation of ICS during run-in period. Bronchodilator reversibility of at least
$12 \%$ and $0.20 \mathrm{~L}$ in FEV $\mathrm{V}_{1}$ over baseline within 15 to 30 minutes after administration of
albuterol pMDI (2-4 inhalations $[90 \mu \mathrm{g}$ per inhalation])
Exclusion Criteria: Reasons for exclusion from the study included severe
asthma (as judged by the investigator), asthma requiring hospitalization once or emer-
gency treatment more than once within the 6 months before the study or requiring
treatment with systemic corticosteroids within the 4 weeks before screening, and/or a
$>10$-pack-year smoking history at screening. Pregnant or breastfeeding

Interventions

1. Budesonide/Formoterol $160 / 9 \mu \mathrm{g}$ (DPI) twice daily

2. Budesonide $160 \mu \mathrm{g}$ (DPI) twice daily

The Symbicort and Budesonide arms of this study are included in this review

The co-primary efficacy variables were changes from baseline in morning predose $\mathrm{FEV}_{1}$
and 12-hour mean $\mathrm{FEV}_{1}$ (from serial spirometry) after administration of the morning
dose of study medication
Two serious adverse events in the BDF group (lobar pneumonia and facial bone fracture)
reported in the paper. No cardiac related serious adverse events were reported in any
group. No deaths occurred in any group (web site data)
Jaeschke 2008 reports no asthma related SAE events.


Corren 2007 (Continued)

\begin{tabular}{|c|c|c|}
\hline Item & Authors' judgement & Description \\
\hline Adequate sequence generation? & Yes & $\begin{array}{l}\text { By study site, computer-generated alloca- } \\
\text { tion schedule using balanced blocks of } 4\end{array}$ \\
\hline Allocation concealment? & Unclear & No information \\
\hline $\begin{array}{l}\text { Blinding? } \\
\text { All outcomes }\end{array}$ & Yes & $\begin{array}{l}\text { Double dummy. Patients received both a } \\
\text { pMDI and DPI containing either active } \\
\text { treatment or placebo of the alternative ac- } \\
\text { tive treatment as appropriate }\end{array}$ \\
\hline $\begin{array}{l}\text { Incomplete outcome data addressed? } \\
\text { All outcomes }\end{array}$ & Yes & $\begin{array}{l}\text { 18/123 discontinued on BDF and 18/121 } \\
\text { Budesonide }\end{array}$ \\
\hline Free of selective reporting? & Yes & $\begin{array}{l}\text { Serious Adverse Events reported in paper } \\
\text { publication }\end{array}$ \\
\hline
\end{tabular}

\section{D5896C00001}

Methods

Participants

Interventions
Study Design:A randomised, double-blind, single-dummy, active-controlled, multicenter, parallel-group study over 12 weeks from October 2003 to February 2005 at 143 centres in the United States. Run-in 4-5 weeks

Population: 619 adolescents and adults (12- 79) years with asthma.

Baseline Characteristics: Mean age 35 years. $\mathrm{FEV}_{1} 76 \%$ predicted. Concomitant inhaled corticosteroids used by $100 \%$ of participants.

Inclusion Criteria: 12 years of age and older, had a documented clinical diagnosis of asthma for at least 6 months prior to screening, and who were in stable condition. Should have received maintenance asthma treatment with inhaled corticosteroids (ICS) for at least 4 weeks prior to the screening visit. $\mathrm{FEV}_{1} \%$ predicted between $60 \%$ and $90 \%$ measured at least 24 hours after the last dose of long-acting $B_{2}$-agonist and 6 hours after the last dose of short-acting $\mathrm{B}_{2}$-agonist.

1. Budesonide/Formoterol 160/4.5 $\mu$ g 2x QD pMDI

2. Budesonide/Formoterol $80 / 4.5 \mu \mathrm{g} 2 \mathrm{x}$ QD pMDI (data not used from this arm)

3. Budesonide/Formoterol $80 / 4.5 \mu \mathrm{g} 2 \mathrm{x}$ BD $\mathrm{pMDI}$

4. Budesonide $160 \mu \mathrm{g} 2 \mathrm{x}$ QD pMDI

Outcomes

Primary variable: evening predose FEV1.

No full paper publication for this study. Web report indicated 2 SAE on BDF 160/4.5 twice daily with a further patient who had a myocardial infarction on the day after the treatment was discontinued. No deaths occurred. No data on asthma SAEs found

Sponsored by AstraZeneca 


\begin{tabular}{|c|c|c|}
\hline Item & Authors' judgement & Description \\
\hline Adequate sequence generation? & Unclear & Not reported \\
\hline Allocation concealment? & Unclear & Not reported \\
\hline $\begin{array}{l}\text { Blinding? } \\
\text { All outcomes }\end{array}$ & Yes & $\begin{array}{l}\text { Double-blind. To maintain blinding with } \\
\text { the twice-daily dosing regimen, all subjects } \\
\text { randomised to receive once-daily dosing } \\
\text { were to take the active treatment in the } \\
\text { evening and a matched placebo device in } \\
\text { the morning }\end{array}$ \\
\hline $\begin{array}{l}\text { Incomplete outcome data addressed? } \\
\text { All outcomes }\end{array}$ & Yes & $12 \%$ drop out in each arm \\
\hline Free of selective reporting? & Unclear & No asthma-related SAE data found \\
\hline
\end{tabular}

Jenkins 2006

Methods

Study Design: A randomised, double-blind, double-dummy, reference -controlled, Multicentre, parallel-group study over 24 weeks from July 2001 to June 2002 at 54 centres in 6 countries. (Australia (11), Austria (6) Czech Republic (15), France(9), Poland (8) Spain (5)) Run-in 2 weeks (on usual ICS)

Participants

Population: 456 adolescents and adults (12-79) years with persistent symptomatic asthma.

Baseline Characteristics: Mean age 46 years. $\mathrm{FEV}_{1} 66 \%$ predicted.Concomitant inhaled corticosteroids used by $100 \%$ of participants.

Inclusion Criteria:Out-patients aged 12 years and older with a diagnosis of asthma (minimum duration 6 months) $\mathrm{FEV}_{1} \%$ predicted between 40?85\%, bronchodilator reversibility by an increase of at least $15 \%$ in $\mathrm{FEV}_{1}$ over baseline after inhalation of a bronchodilator. For patients aged 18 years and older, an increase in baseline FEV1 of at least $200 \mathrm{~mL} 15$ to $30 \mathrm{~min}$ post bronchodilator was required at study entry (visit 1 ). All patients had used ICS for at least 4 months at a constant daily dose of at least $750 \mathrm{mcg}$ for at least 4 weeks before study entry.

Exclusion Criteria:If asthma deteriorated, resulting in a change of asthma therapy. Total asthma symptom score had to be $>1$ on a scale of 0 ? 6 for at least 4 of the last 7 days of run-in. The total asthma symptom score was the sum of daytime and night-time asthma symptom scores, each measured on a scale of $0-3$ (where $0=$ no symptoms and $3=$ unable to perform usual activities (or to sleep) because of asthma)

Interventions

1. Budesonide/Formoterol $320 / 9 \mu \mathrm{g}$ two inhalations BD + Placebo BD

2. Budesonide $400 \mu \mathrm{g}$ two inhalations $\mathrm{BD}+$ Formoterol $9 \mu \mathrm{g}$ two inhalations $\mathrm{BD}+$ Placebo BD 
3. Budesonide $400 \mu \mathrm{g}$ two inhalations BD + Placebo BD

This was the treatment for the first twelve weeks, then group three was split between the first two treatments. DPI delivery

\begin{tabular}{ll} 
Outcomes & $\begin{array}{l}\text { The primary efficacy variable was morning PeakExpiratory Flow (PEF) as registered daily } \\
\text { in diary cards } \\
\text { Paper reports } 5 \text { patients with SAE on BDF and two on Budesonide. One death occurred } \\
\text { in the BDF group from Pulmonary Embolism, but as this was after } 17 \text { weeks when there } \\
\text { was no budesonide control arm, this has not been included in the meta-analysis } \\
\text { Data from AstraZeneca shows } 7 \text { patients with SAE on BDF and } 3 \text { on Budesonide in the } \\
\text { first } 12 \text { weeks of the study. This has been used in the meta-analysis. It is not clear why } \\
\text { the paper reports different numbers }\end{array}$ \\
\hline Notes & Sponsored by AstraZeneca
\end{tabular}

Risk of bias

\begin{tabular}{|c|c|c|}
\hline Item & Authors' judgement & Description \\
\hline Adequate sequence generation? & Yes & $\begin{array}{l}\text { Individual treatment codes were computer } \\
\text { generated in balanced blocks of } 8 \text { at As- } \\
\text { traZeneca R\&D, Lund, Sweden }\end{array}$ \\
\hline Allocation concealment? & Yes & $\begin{array}{l}\text { codes were then assigned to patients and } \\
\text { kept in sealed envelopes until data analysis }\end{array}$ \\
\hline $\begin{array}{l}\text { Blinding? } \\
\text { All outcomes }\end{array}$ & Yes & Double-blind \\
\hline $\begin{array}{l}\text { Incomplete outcome data addressed? } \\
\text { All outcomes }\end{array}$ & Yes & $400 / 456(88 \%)$ completed the study \\
\hline Free of selective reporting? & Yes & $\begin{array}{l}\text { SAE data in paper, but this did not match } \\
\text { final data from sponsors }\end{array}$ \\
\hline
\end{tabular}

\section{Kuna 2006}

Methods

Participants
Study design: A randomised, double-blind, double-dummy, active-controlled, Multicentre, parallel-group study over 12 weeks from November 1999 to July 2000 at 60 centres in 8 countries. (Finland (5), Germany (17), Mexico (4), New Zealand (3) Norway (6), Poland (7), Russia (5), Sweden (13) Run-in 2 weeks in which all patients received budesonide $200 \mathrm{mcg}$ daily (half the previous average dose)

Population: 616 adults (18-80) years with mild to moderate persistent asthma.

Baseline Characteristics: Mean age 45 years. FEV $_{1}$ 78.5\% predicted. Concomitant inhaled corticosteroids used by $100 \%$ of participants.

Inclusion Criteria: 18 years of age and older, a diagnosis of asthma (minimum duration: 6 months) that was not optimally controlled despite a daily ICS dose of 200 to $500 \mathrm{mg}$ 
Kuna 2006 (Continued)

for at least 30 days before study entry. $\mathrm{FEV}_{1} \%$ predicted of 60 to $90 \%$, bronchodilator
reversibility by an increase of at least $12 \%$ in $\mathrm{FEV}_{1}$ over baseline after inhalation of either
$1 \mathrm{mg}$ of terbutaline or salbutamol $0.4 \mathrm{mg}$.
Exclusion Criteria: used any systemic corticosteroids within the previous 30 days; sea-
sonal asthma (defined as asthma exacerbated by seasonal increases in aero allergens); a
respiratory infection in the 4 weeks before study entry; a severe cardiovascular disorder
or any other significant disease; used 3 -blocker therapy (including eye drops) or had a
history of heavy smoking (X10 pack-years), women of child-bearing potential who were
pregnant or who failed to use acceptable contraceptive measures,

\begin{tabular}{l|l}
\hline Interventions & $\begin{array}{l}\text { 1. Budesonide/Formoterol 80/4.5 } \mu \mathrm{g} 2 \mathrm{x} \text { QD } \\
\text { 2. Budesonide/Formoterol 80/4.5 } \mu \mathrm{g} \mathrm{BD} \\
\text { 3. Budesonide } 200 \mu \mathrm{g} \text { QD } \\
\text { Delivery was DPI and all arms received equivalent delivered dose of } 160 \text { mcg budesonide } \\
\text { daily }\end{array}$ \\
\hline Outcomes & $\begin{array}{l}\text { The primary variable was morning PEF. } \\
\text { "Seven serious adverse events were reported:two in the once daily BDF group, one in the } \\
\text { twice daily BDF group and four in the budesonide group." Although the three asthma } \\
\text { SAEs were not described by treatment group in the paper or the web report, Jaeschke } \\
\text { 2008 indicates one on BDF and two events on budesonide, with one hospitalisation for } \\
\text { asthma in each group. No mortality }\end{array}$ \\
\hline Notes & Sponsored by AstraZeneca \\
\hline
\end{tabular}

Risk of bias

\begin{tabular}{|c|c|c|}
\hline Item & Authors' judgement & Description \\
\hline Adequate sequence generation? & Unclear & Not described \\
\hline Allocation concealment? & Unclear & Not described \\
\hline $\begin{array}{l}\text { Blinding? } \\
\text { All outcomes }\end{array}$ & Yes & $\begin{array}{l}\text { To ensure treatment blinding, a double- } \\
\text { dummy design was used so that patients } \\
\text { received four successively numbered Tur- } \\
\text { buhalers, with the corresponding placebo } \\
\text { inhalers being identical in appearance to } \\
\text { those containing active medication }\end{array}$ \\
\hline $\begin{array}{l}\text { Incomplete outcome data addressed? } \\
\text { All outcomes }\end{array}$ & Yes & $555 / 616(90 \%)$ completed the study \\
\hline Free of selective reporting? & Yes & SAE reported in paper by treatment group \\
\hline
\end{tabular}




Study Design: A randomised, double-blind, double-dummy, parallel-group study over
12 weeks from April
2002 to February 2003 at 62 centres in Brazil (7), Bulgaria (5), Canada (9), Hungary
(9), Mexico (7), the Philippines (6), Thailand (5), UK (14)). Run-in 2 weeks on pre-
study ICS but LABA was withdrawn from the 15\% previously treated with LABA and
ICS

Population: 680 adolescents and adults $(12-79)$ years with asthma.

Baseline Characteristics: Mean age 40 years. FEV $_{1} 70 \%$ predicted. Concomitant inhaled corticosteroids used previously by $100 \%$ of participants (mean dose $770 \mathrm{mcg} /$ day)

Inclusion Criteria: 12 years of age and older with asthma for at least 6 months, who were inadequately controlled on ICS alone, FEV1 \% predicted between $50 \%$ and $90 \%$, bronchodilator reversibility by an increase of at least $12 \%$ in $\mathrm{FEV}_{1}$ after inhalation of terbutaline $1 \mathrm{mg}$, a history of daily ICS use (stable dose of $500 ? 1600 \mathrm{mcg} /$ day within 30 days prior to enrolment) for at least 3 months. Symptoms must have been present on at least 4 of the last 7 days of run-in

Exclusion Criteria: not defined

Interventions
$\begin{aligned} & \text { 1. Budesonide } 200 \mu \mathrm{g} 2 \mathrm{x} \text { BD pMDI (CFC propellant) } \\ & \text { 2. Budesonide/Formoterol 160/4.5 } \mu \mathrm{g} \text { 2x BD DPI } \\ & \text { 3. Budesonide/Formoterol 160/4.5 } \mu \mathrm{g} 2 \mathrm{xD} \text { pMDI (HFA propellant) } \\ & \text { All delivered the same daily dose of budesonide }\end{aligned}$

Outcomes

The primary efficacy end-point was the change in morning peak expiratory flow (PEF) from baseline (mean of the last 10 days of run-in) to the mean value over the 12-week treatment period

Paper report: "No deaths occurred. Four subjects experienced serious adverse events, two in the budesonide group (joint dislocation, asthma) and two in BDF pMDI (menorrhagia, increased liver enzymes)."

Notes Sponsored by AstraZeneca.

Risk of bias

\begin{tabular}{l|l|l}
\hline Item & Authors' judgement & Description \\
\hline Adequate sequence generation? & Yes & $\begin{array}{l}\text { Patients were randomised sequentially in } \\
\text { blocks of six using a computer-generated } \\
\text { randomisation schedule }\end{array}$ \\
\hline Allocation concealment? & Yes & $\begin{array}{l}\text { Eligible patients were consecutively allo- } \\
\text { cated the lowest available randomisation } \\
\text { code. In view of double-dummy design this } \\
\text { is considered satisfactory }\end{array}$ \\
\hline $\begin{array}{l}\text { Blinding? } \\
\text { All outcomes }\end{array}$ & Yes & $\begin{array}{l}\text { Double-blind, double-dummy. To main- } \\
\text { tain blinding, each patient also received a } \\
\text { placebo device }\end{array}$ \\
\hline
\end{tabular}


Morice 2007 (Continued)

\begin{tabular}{l|l|l}
\hline $\begin{array}{l}\text { Incomplete outcome data addressed? } \\
\text { All outcomes }\end{array}$ & Yes & $600 / 680(88 \%)$ completed the study \\
\hline Free of selective reporting? & Yes & $\begin{array}{l}\text { Full SAE data available from paper by treat- } \\
\text { ment group and cause }\end{array}$ \\
\hline
\end{tabular}

\section{Morice 2008}

Methods

Study Design: A randomised, double-blind, double-dummy, parallel-group study over 12 weeks from June 2002 to May 2003 at 53 centres in Argentina (4), Brazil (6), Denmark (14), Hong Kong (1), Mexico (6), Poland (4), Slovakia (12), and Taiwan (6))

Run-in 2 weeks on previous ICS dose (but previous LABA may have been withdrawn? not made clear in the paper)

Participants

Population: 622 children (6-11) years with symptomatic asthma.

Baseline Characteristics: Mean age 8 years. FEV $_{1} \quad 82 \%$ predicted. Concomitant inhaled corticosteroids used by $100 \%$ of participants ( 375 to $100 \mathrm{mcg}$ daily).

Inclusion Criteria: Paediatric out-patients (6-11 years) with asthma and a history of clinically important exercise-induced bronchoconstriction, daily using 375-1000 $\mu \mathrm{g}$ of inhaled glucocorticosteroids (GCSs), peak expiratory flow (PEF) at least $50 \%$ of predicted normal value (pre bronchodilator). Had to have a total asthma-symptom score (night-time plus daytime) of at least 1 on at least 4 of the last 7 days of the run-in period and a mean morning PEF (mPEF) during the last 7 days of the run-in period of 50-85\% of post bronchodilatory PEF, measured at Visit 1 (enrolment).

Exclusion Criteria: inability to use DPI and Peak Flow meter.

\begin{tabular}{|c|c|}
\hline Interventions & $\begin{array}{l}\text { 1. Budesonide } 100 \mu \mathrm{g} 2 \mathrm{x} \text { BD pMDI } \\
\text { 2. Budesonide/Formoterol } 80 / 4.5 \mu \mathrm{g} 2 \mathrm{x} \text { BD DPI } \\
\text { 3. Budesonide/Formoterol } 80 / 4.5 \mu \mathrm{g} 2 \mathrm{x} \text { BD pMDI } \\
\text { Dose of budesonide was equivalent in each arm ( } 100 \text { metered dose equivalent to } 160 \\
\text { delivered dose) }\end{array}$ \\
\hline
\end{tabular}

Outcomes

The primary efficacy end-point was the change in morning peak expiratory flow (PEF) from baseline (mean of the last 10 days of run-in) to the mean value over the 12-week treatment period

Paper reports: "Five patients reported serious adverse events: 3 in budesonide group (asthma aggravation (2), nervousness), 2 BDF DPI (acute sinusitis, migraine). No deaths were reported."

Notes Sponsored by AstraZeneca

Risk of bias

\begin{tabular}{lll}
\hline Item & Authors' judgement & Description \\
\hline Adequate sequence generation? & Yes & $\begin{array}{l}\text { Patients were randomised sequentially in } \\
\text { blocks of six using a computer-generated } \\
\text { randomisation schedule }\end{array}$
\end{tabular}


Morice 2008 (Continued)

\begin{tabular}{lll}
\hline Allocation concealment? & Unclear & No details \\
\hline $\begin{array}{l}\text { Blinding? } \\
\text { All outcomes }\end{array}$ & Yes & $\begin{array}{l}\text { Double blind (all patients used a placebo } \\
\text { inhaler and an active inhaler) }\end{array}$ \\
\hline $\begin{array}{l}\text { Incomplete outcome data addressed? } \\
\text { All outcomes }\end{array}$ & Yes & $583 / 622(94 \%)$ completed the study \\
\hline Free of selective reporting? & Yes & $\begin{array}{l}\text { SAE reported by treatment group and cause } \\
\text { in paper }\end{array}$ \\
\hline
\end{tabular}

\section{Noonan 2006}

Methods
Randomized, double-blind, double-dummy, multicenter, placebo-controlled study over 12 weeks from July 2002 to January 2004 at 84 US centres (respiratory or allergy speciality clinical practice) Run-in 2 weeks

\begin{tabular}{|c|c|c|}
\hline Participants & \multicolumn{2}{|c|}{$\begin{array}{l}\text { Population: } 596 \text { adolescents and adults (12-87) years with moderate to severe persistent } \\
\text { asthma. BDF } 124 \text { patients, BD + F } 115 \text { patients, Budesonide } 109 \text { patients } \\
\text { Baseline Characteristics: Mean age } 41 \text { years. } \mathrm{FEV}_{1} 67 \% \text { predicted. Concomitant in- } \\
\text { haled corticosteroids used by } 100 \% \text { of participants. } \\
\text { Inclusion Criteria: Moderate to severe persistent asthma chronically treated with a } \\
\text { medium to high dose of ICS, } \mathrm{FEV}_{1} \% \text { predicted within the entrance range of } 45 \% \text { to } \\
85 \% \text {, bronchodilator reversibility of } \mathrm{FEV}_{1} \text { of at least } 12 \% \text { and } 0.20 \mathrm{~L} \text { from the pre- } \\
\text { albuterol baseline value within } 15 \text { to } 30 \text { minutes after administration of a standard dose } \\
\text { of salbutamol. } \\
\text { Exclusion Criteria: Requiring hospitalisation once or emergency treatment more than } \\
\text { once in the preceding } 6 \text { months, greater than } 10 \text {-pack-per-year smoking history }\end{array}$} \\
\hline Interventions & \multicolumn{2}{|c|}{$\begin{array}{l}\text { 1. Budesonide } 160 \mathrm{mcg} \text { twice daily } \\
\text { 2. Budesonide/Formoterol } 160 / 9 \mathrm{mcg} \text { pMDI twice daily } \\
\text { 3. Budesonide pMDI and Formoterol DPI } 160 / 9 \text { mcg twice daily }\end{array}$} \\
\hline Outcomes & \multicolumn{2}{|c|}{$\begin{array}{l}\text { The co-primary efficacy variables were baseline adjusted average 12-hour FEV } I_{I} \text { and } \\
\text { predose FEV } I_{I} \text {. } \\
\text { "Nine subjects had SAEs during double-blind treatment: } 4 \text { on BDF pMDI (asthma -2, } \\
\text { urti and ECG T wave inversion), } 2 \text { in the formoterol group and } 3 \text { in the budesonide + } \\
\text { formoterol group (small intestine obstruction, abdominal injury, pneumonia)." } \\
\text { Web data found on AZ clinical trials web site SD-039-0717 }\end{array}$} \\
\hline Notes & \multicolumn{2}{|c|}{$\begin{array}{l}\text { Sponsored by AstraZeneca. Jaeschke } 2008 \text { excluded this study as there were more than } \\
20 \% \text { dropouts. }\end{array}$} \\
\hline \multicolumn{3}{|l|}{ Risk of bias } \\
\hline Item & Authors' judgement & Description \\
\hline Adequate sequence generation? & Yes & Computer generated allocation schedule \\
\hline
\end{tabular}




\begin{tabular}{lll}
\hline Allocation concealment? & Yes & Identical packages shipped to centres \\
\hline $\begin{array}{l}\text { Blinding? } \\
\text { All outcomes }\end{array}$ & Yes & Double blind \\
\hline $\begin{array}{l}\text { Incomplete outcome data addressed? } \\
\text { All outcomes }\end{array}$ & Yes & $\begin{array}{l}23 \% \text { withdrawals in combined arms and } \\
28 \% \text { in budesonide arm }\end{array}$ \\
\hline \begin{tabular}{l} 
Free of selective reporting? \\
\hline
\end{tabular} & Yes & Full SAE data on web site \\
\hline
\end{tabular}

\section{O’Byrne 2001}

Methods

Participants
Study design: A randomised, double-blind, parallel-group study over 12 months from January 1998 to February 2000 at 198 centres in 17 countries. Run-in 1 month

Population: 1970 adults (18-76) years with mild asthma, (Group A - 698) and mildto-moderate asthma (Group B - 1,272)

\section{Baseline Characteristics:}

(Group A) Mean age 31 years. FEV $_{1}$ 90\% predicted. Concomitant inhaled corticosteroids used by $0 \%$ of participants.

(Group B) Mean age 37 years. FEV $187 \%$ predicted. Concomitant inhaled corticosteroids used by $100 \%$ of participants.

Inclusion Criteria: 12 years of age and older. Diagnosis of stable asthma, according to the American Thoracic Society (ATS).

(Group A) had used no inhaled corticosteroid for at least 3 months, pre-bronchodilator $\mathrm{FEV}_{1} \%$ predicted at least $70 \%$ at visit 1.15 min post bronchodilator $\mathrm{FEV}_{1} \%$ predicted at least $80 \%$ at visit 1 (2x0.5 mg Bricanyl Turbuhaler).

(Group B) taking no more than $400 \mu \mathrm{g}$ of inhaled budesonide or its equivalent

for at least 3 months, pre-bronchodilator $\mathrm{FEV}_{1} \%$ predicted at least $50 \%$ at visit 1.15 min post bronchodilator $\mathrm{FEV}_{1} \%$ predicted at least $70 \%$ at visit 1 (2x0.5 mg Bricanyl Turbuhaler).

Exclusion Criteria: use of oral GCS within 3 months prior to visit 1, beta-blocker therapy (eyedrops included).pregnant and/or lactating women or women not using acceptable contraceptives as judged by the investigator, patients with a history of smoking more than 15 pack-years

Interventions
THIS REPORT RELATES TO PATIENTS GIVEN 200 mcg Budesonide twice daily (Group A)

1. Budesonide $200 \mu \mathrm{g}$

2. Budesonide and Formoterol 200 and $4.5 \mu \mathrm{g}$

Placebo arm from Group A was not included in this review

(Group B)

1. Budesonide $200 \mu \mathrm{g}$

2. Budesonide and Formoterol 200 and $4.5 \mu \mathrm{g}$

3. Budesonide $400 \mu \mathrm{g}$

4. Budesonide and Formoterol 400 and $4.5 \mu \mathrm{g}$ 


\begin{tabular}{|c|c|c|}
\hline Outcomes & \multicolumn{2}{|c|}{$\begin{array}{l}\text { Primary variable was time to first severe asthma exacerbation, expressed as the risk for a } \\
\text { first severe exacerbation, and rate (proportion) of poorly controlled days } \\
\text { Serious Adverse Events are not mentioned at all in the paper publication and the web } \\
\text { report (SD-037-0345) only gives total numbers of patients with SAEs for Group A and } \\
\text { B (with no indication of treatment group) } \\
\text { AstraZeneca have provided a breakdown of all-cause SAE and asthma-related SAE (As- } \\
\text { traZeneca Data on file 2008) } \\
\text { There was one death that was not reported in the paper, but mentioned in the web } \\
\text { report as probably due to 'septic shock' in group A. Sears } 2008 \text { indicates that the death } \\
\text { was also related to status asthmaticus and was in a patient taking budesonide/formoterol } \\
\text { combination treatment. The full report of the death from the sponsors is: "One of the } \\
\text { deaths occurred in a } 35 \text { year old female after an } 8 \text { day hospitalization for a severe asthma } \\
\text { attack leading to intubation, ventilation, and nosocomial pneumonia with septic shock. } \\
\text { " }\end{array}$} \\
\hline Notes & \multicolumn{2}{|c|}{ Sponsored by AstraZeneca } \\
\hline \multicolumn{3}{|l|}{ Risk of bias } \\
\hline Item & Authors' judgement & Description \\
\hline Adequate sequence generation? & Yes & Computer generated random numbers \\
\hline Allocation concealment? & Yes & $\begin{array}{l}\text { Opaque consecutive numbered envelopes } \\
\text { containing assignment }\end{array}$ \\
\hline $\begin{array}{l}\text { Blinding? } \\
\text { All outcomes }\end{array}$ & Yes & Double-blind. Identical placebo \\
\hline $\begin{array}{l}\text { Incomplete outcome data addressed? } \\
\text { All outcomes }\end{array}$ & Yes & $\begin{array}{l}81 \% \text { in Group A and } 87 \% \text { in Group B } \\
\text { completed the study }\end{array}$ \\
\hline Free of selective reporting? & Yes & $\begin{array}{l}\text { SAE data provided by sponsors and found } \\
\text { from other sources }\end{array}$ \\
\hline
\end{tabular}

\section{O’Byrne 2001a}

Methods

Study design: A randomised, double-blind, parallel-group study over 12 months from January 1998 to February 2000 at 198 centres in 17 countries. Run-in 1 month

Participants

Population: 1970adults (18-76) years with mild asthma, (Group A - 698) and mildto-moderate asthma (Group B - 1,272)

\section{Baseline Characteristics:}

(Group A) Mean age 31 years. FEV $190 \%$ predicted. Concomitant inhaled corticosteroids used by $0 \%$ of participants.

(Group B) Mean age 37 years. FEV $_{1} 87 \%$ predicted. Concomitant inhaled corticosteroids used by $100 \%$ of participants.

Inclusion Criteria: 12 years of age and older. Diagnosis of stable asthma, according to 


\begin{tabular}{|c|c|}
\hline & $\begin{array}{l}\text { the American Thoracic Society (ATS). } \\
\text { (Group A) had used no inhaled corticosteroid for at least } 3 \text { months, pre-bronchodilator } \\
\mathrm{FEV}_{1} \% \text { predicted at least } 70 \% \text { at visit } 1.15 \text { min post bronchodilator } \mathrm{FEV}_{1} \% \text { predicted } \\
\text { at least } 80 \% \text { at visit } 1 \text { ( } 2 \times 0.5 \mathrm{mg} \text { Bricanyl Turbuhaler). } \\
\text { (Group B) taking no more than } 400 \mu \mathrm{g} \text { of inhaled budesonide or its equivalent } \\
\text { for at least } 3 \text { months, pre-bronchodilator } \mathrm{FEV}_{1} \% \text { predicted at least } 50 \% \text { at visit } 1.15 \\
\text { min post bronchodilator } \mathrm{FEV}_{1} \% \text { predicted at least } 70 \% \text { at visit } 1 \text { ( } 2 \times 0.5 \mathrm{mg} \text { Bricanyl } \\
\text { Turbuhaler). } \\
\text { Exclusion Criteria: use of oral GCS within } 3 \text { months prior to visit } 1 \text {, beta-blocker therapy } \\
\text { (eyedrops included).pregnant and/or lactating women or women not using acceptable } \\
\text { contraceptives as judged by the investigator, patients with a history of smoking more } \\
\text { than } 15 \text { pack-years }\end{array}$ \\
\hline Interventions & $\begin{array}{l}\text { THIS REPORT RELATES TO PATIENTS GIVEN } 400 \text { mcg Budesonide twice daily } \\
\text { (Group A) } \\
\text { 1. Budesonide } 200 \mu \mathrm{g} \\
\text { 2. Budesonide and Formoterol } 200 \text { and } 4.5 \mu \mathrm{g} \\
\text { Placebo arm from Group A was not included in this review } \\
\text { (Group B) } \\
\text { 1. Budesonide } 200 \mu \mathrm{g} \\
\text { 2. Budesonide and Formoterol } 200 \text { and } 4.5 \mu \mathrm{g} \\
\text { 3. Budesonide } \mathbf{4 0 0} \boldsymbol{\mu g} \\
\text { 4. Budesonide and Formoterol } \mathbf{4 0 0} \text { and } \mathbf{4 . 5} \boldsymbol{\mu g}\end{array}$ \\
\hline
\end{tabular}

Outcomes

The primary variable was time to first severe asthma exacerbation, expressed as the risk for a first severe exacerbation, and rate (proportion) of poorly controlled days

Serious Adverse Events are not mentioned at all in the paper publication and the web report (SD-037-0345) only gives total numbers of patients with SAEs for Group A and $\mathrm{B}$ (with no indication of treatment group)

AstraZeneca have provided a breakdown of all-cause SAE and asthma-related SAE which has been used in the meta-analysis. (AstraZeneca Data on file 2008)

Notes Sponsored by AstraZeneca

\section{Risk of bias}

\begin{tabular}{lll}
\hline Item & Authors' judgement & Description \\
\hline Adequate sequence generation? & Yes & Computer generated random numbers \\
\hline Allocation concealment? & Yes & $\begin{array}{l}\text { Opaque consecutive numbered envelopes } \\
\text { containing assignment }\end{array}$ \\
\hline $\begin{array}{l}\text { Blinding? } \\
\text { All outcomes }\end{array}$ & Yes & Double-blind. Identical placebo \\
\hline $\begin{array}{l}\text { Incomplete outcome data addressed? } \\
\text { All outcomes }\end{array}$ & Yes & $\begin{array}{l}81 \% \text { in Group A and } 87 \% \text { in Group B } \\
\text { completed the study }\end{array}$
\end{tabular}




\section{Pauwels 1997}

Study Design:A randomised, double-blind, Multicentre, parallel-group study over 12
months at 71 centres in 9 countries. (Belgium, Canada, the Netherlands, Israel, Italy,
Luxembourg, Norway, Spain and the United Kingdom). Run-in 4 weeks on 800 mcg
twice daily

Study Design: A randomised, double-blind, Multicentre, parallel-group study over 12
months at 71 centres in 9 countries. (Belgium, Canada, the Netherlands, Israel, Italy,
Luxembourg, Norway, Spain and the United Kingdom) Run-in 4 weeks on 800 mcg
twice daily.
Population: 852 adults $(18-70)$ years with persistent symptomatic asthma.
Baseline Characteristics: Mean age 42 years. FEV $76 \%$ predicted. Concomitant in-
haled corticosteroids used by $100 \%$ of participants (mean dose 820 mcg/day).
Inclusion Criteria: 18 to 70 years old, who had had asthma for at least six months
and had been treated with an inhaled glucocorticoid for at least three months. FEV $1 \%$
predicted at least $50 \%$, bronchodilator reversibility by an increase of at least $15 \%$ in
FEV ${ }_{1}$ over baseline after inhalation of 1 mg of terbutaline. Stable asthma during run-in
and compliant with treatment.
Exclusion Criteria: Three or more courses of oral glucocorticoids or had been hospi-
talized for asthma during the previous six months. Taking more than 2000 mcg of be-
clomethasone or 1600 mcg of budesonide daily by pressurized metered dose inhaler, 800
mcg of budesonide daily by Turbuhaler dry-powder inhaler or 800 mcg of fluticasone
daily
daily

$\begin{array}{ll}\text { Interventions } & \begin{array}{l}\text { Budesonide } 100 \mu \mathrm{g} \text { BD + Placebo } \\ \text { Budesonide100 } \boldsymbol{\mu g}+\text { Formoterol } 12 \boldsymbol{\mu g} \text { BD }(\mathbf{9} \boldsymbol{\mu g} \text { delivered dose })\end{array} \\ \text { Budesonide } 400 \mu \mathrm{g} \text { BD + Placebo } \\ \text { Budesonide } 400 \mu \mathrm{g}+\text { Formoterol } 12 \mu \mathrm{g} \text { BD }(9 \mu \mathrm{g} \text { delivered dose }) \\ \text { Delivery was DPI }\end{array}$

Outcomes

Two primary outcome variables, the rate of severe exacerbations and the rate of mild exacerbations, according to treatment group

SAE data (all-cause and asthma related) provided by AstraZeneca from Data on file 2008 No SAE data given in the paper publication, except asthma admissions but the sponsors have provided data on file for the number of patients with all-cause and asthma-related SAEs

\begin{tabular}{ll} 
Notes & Sponsored by AstraZeneca \\
\hline
\end{tabular}

\section{Risk of bias}

\begin{tabular}{lll}
\hline Item & Authors' judgement & Description \\
\hline Adequate sequence generation? & Yes & $\begin{array}{l}\text { Computer generated randomisation sched- } \\
\text { ule (Ni Chroinin 2005) }\end{array}$
\end{tabular}


Pauwels 1997 (Continued)

\begin{tabular}{l|l|l}
\hline Allocation concealment? & Yes & $\begin{array}{l}\text { The patients were randomly assigned to } \\
\text { treatment groups in balanced blocks of four } \\
\text { at each centre }\end{array}$ \\
\hline $\begin{array}{l}\text { Blinding? } \\
\text { All outcomes }\end{array}$ & Yes & Double-blind \\
\hline $\begin{array}{l}\text { Incomplete outcome data addressed? } \\
\text { All outcomes }\end{array}$ & Yes & $694 / 852(81 \%)$ completed the study \\
\hline Free of selective reporting? & Yes & SAE data provided from sponsors \\
\hline
\end{tabular}

\section{Pauwels 1997a}

Methods

Participants

Study Design:A randomised, double-blind, Multicentre, parallel-group study over 12 months at 71 centres in 9 countries. (Belgium, Canada, the Netherlands, Israel, Italy, Luxembourg, Norway, Spain and the United Kingdom). Run-in 4 weeks on 800 mcg twice daily

Participants
months at 71 centres in 9 countries. (Belgium, Canada, the Netherlands, Israel, Italy,
Luxembourg, Norway, Spain and the United Kingdom) Run-in 4 weeks on 800 mcg
twice daily.
Population: 852 adults $(18-70)$ years with persistent symptomatic asthma.
Baseline Characteristics: Mean age 42 years. FEV $76 \%$ predicted. Concomitant in-
haled corticosteroids used by $100 \%$ of participants (mean dose 820 mcg/day).
Inclusion Criteria: 18 to 70 years old, who had asthma for at least six months and
had been treated with an inhaled glucocorticoid for at least three months. FEV $\%$
predicted at least $50 \%$, bronchodilator reversibility by an increase of at least $15 \%$ in
FEV $V_{1}$ over baseline after inhalation of 1 mg of terbutaline. Stable asthma during run-in
and compliant with treatment.
Exclusion Criteria: Three or more courses of oral glucocorticoids or had been hospi-
talized for asthma during the previous six months. Taking more than 2000 mcg of be-
clomethasone or 1600 mcg of budesonide daily by pressurized metered dose inhaler, 800
mcg of budesonide daily by Turbuhaler dry-powder inhaler or 800 mcg of fluticasone
daily

\begin{tabular}{|c|c|}
\hline Interventions & $\begin{array}{l}\text { This report deals with patients on } 800 \text { mcg budesonide daily } \\
\text { Budesonide } 100 \mu \mathrm{g} \text { BD + Placebo } \\
\text { Budesonide } 100 \mu \mathrm{g}+\text { Formoterol } 12 \mu \mathrm{g} \text { BD }(9 \mu \mathrm{g} \text { delivered dose) } \\
\text { Budesonide } \mathbf{4 0 0} \boldsymbol{\mu g} \text { BD + Placebo } \\
\text { Budesonide } \mathbf{4 0 0} \boldsymbol{\mu g}+\text { Formoterol } \mathbf{1 2} \boldsymbol{\mu g} \text { BD (9 } \boldsymbol{\mu g} \text { delivered dose) } \\
\text { Delivery was DPI }\end{array}$ \\
\hline
\end{tabular}

Outcomes

Two primary outcome variables, the rate of severe exacerbations and the rate of mild exacerbations, according to treatment group

SAE data (all-cause and asthma related) provided by AstraZeneca from Data on file 2008 No SAE data given in the paper publication, except asthma admissions but the sponsors 
have provided data on file for the number of patients with all-cause and asthma-related SAEs. There was one death (unrelated to asthma) in a participant on Budesonide 400 and Formoterol 12 twice daily

\begin{tabular}{l|ll}
\hline Notes & Sponsored by AstraZeneca & \\
\hline Risk of bias & & Description \\
\hline Item & Authors' judgement & Computer generated randomisation sched- \\
\hline Adequate sequence generation? & Yes & ule (Ni Chroinin 2005) \\
\hline $\begin{array}{l}\text { Allocation concealment? } \\
\begin{array}{l}\text { Blinding? } \\
\text { All outcomes }\end{array}\end{array}$ & $\begin{array}{l}\text { The patients were randomly assigned to } \\
\text { treatment groups in balanced blocks of four } \\
\text { at each centre }\end{array}$ \\
\hline $\begin{array}{l}\text { Incomplete outcome data addressed? } \\
\text { All outcomes }\end{array}$ & Yes & Double-blind \\
\hline \begin{tabular}{l} 
Free of selective reporting? \\
\hline
\end{tabular}
\end{tabular}

Peters 2008

Methods

Participants
Study Design: A randomised, double-blind, single-dummy, Multicentre, Phase III,parallel-group study over 52 weeks from August 2003 to February 2005 at 77 centres in the United States

Run-in 2 weeks on budesonide 320 mcg bd (LABA discontinued).

Population: 708 adults and adolescents $(12-81)$ years with moderate to severe persistent asthma

Baseline Characteristics: Mean age 40 years. $\mathrm{FEV}_{1} 72 \%$ predicted. Concomitant inhaled corticosteroids used by $100 \%$ of participants (mean daily dose around $500 \mathrm{mcg}$ ) Inclusion Criteria: 12 years of age and older with a documented clinical diagnosis of moderate-to-severe asthma for at least 6 months prior to screening, received maintenance asthma treatment with a stable dose of inhaled corticosteroids (ICS) for at least 4 weeks prior to the screening visit. $\mathrm{FEV}_{1} \%$ predicted of at least $45 \%$, bronchodilator reversibility by an increase of at least $12 \%$ in $\mathrm{FEV}_{1}$ and at least $0.20 \mathrm{~L}$ from baseline within 15 ?30 minutes after administration of a fast-acting beta2-agonist or have a documented history of this level of reversibility after administration of a fast-acting beta2-agonist while using ICS within 1 year of screening. To require two asthma controller medications or to have had a history of at least two asthma-related nighttime awakenings or at least three uses of rescue medication within the week before screening. Required to be nonsmokers, with a less than 20 pack-year smoking history.

Exclusion Criteria: had a significant disease or disorder (e.g. cardiovascular, pulmonary 


\begin{tabular}{|c|c|}
\hline & $\begin{array}{l}\text { [other than asthma], hepatic, renal) that, in the opinion of the investigator, may put the } \\
\text { patient at risk or influence the results of the study. In addition, treated with systemic } \\
\text { corticosteroids within } 30 \text { days before screening or during the period between screening } \\
\text { and randomisation were excluded }\end{array}$ \\
\hline Interventions & $\begin{array}{l}\text { 1. Budesonide/Formoterol } 640 / 18 \mu \mathrm{g} \mathrm{BD} \\
\text { 2. Budesonide/ Formoterol } 320 / 9 \mu \mathrm{g} \mathrm{BD} \text { (this arm was not used in the analysis for } \\
\text { this review) } \\
\text { 3. Budesonide } 640 \mu \mathrm{g} \mathrm{BD} \\
\text { Delivery was pMDI }\end{array}$ \\
\hline
\end{tabular}

Outcomes

Because this study was a safety study, no single variable was considered primary. However, spirometry (predose and 2-hour post dose $\mathrm{FEV}_{1}$ ) was conducted at each study visit to detect any untoward decreases in lung function over the 52 -week period

Web report indicates 21 patients with SAE on BDF 640/18 bd and 5 on budesonide 640 bd. No deaths in the study

Paper reports one asthma SAE in the BDF 640/18 bd group.

\begin{tabular}{ll}
\hline Notes & Sponsored by AstraZeneca (SD-039-0728) \\
\hline
\end{tabular}

\section{Risk of bias}

\begin{tabular}{|c|c|c|}
\hline Item & Authors' judgement & Description \\
\hline Adequate sequence generation? & Yes & $\begin{array}{l}\text { randomised using a } 3: 1: 1 \text { overall randomi- } \\
\text { sation scheme and a computer-generated } \\
\text { allocation schedule }\end{array}$ \\
\hline Allocation concealment? & Unclear & Not reported \\
\hline $\begin{array}{l}\text { Blinding? } \\
\text { All outcomes }\end{array}$ & Yes & Double blind \\
\hline $\begin{array}{l}\text { Incomplete outcome data addressed? } \\
\text { All outcomes }\end{array}$ & Yes & $579 / 708(82 \%)$ completed the study \\
\hline Free of selective reporting? & Yes & $\begin{array}{l}\text { SAE data available from paper and web re- } \\
\text { port. }\end{array}$ \\
\hline
\end{tabular}




\begin{tabular}{|c|c|}
\hline Methods & $\begin{array}{l}\text { Study Design:A randomised, double-blind, double-dummy, active-controlled, Multi- } \\
\text { centre, parallel-group study over } 12 \text { weeks from March, } 2002 \text { to March, } 2003 \text { at } 80 \\
\text { centres in } 8 \text { countries (Austria (5), Belgium (11), Czech Republic (14), France (11), } \\
\text { Hungary (12), Poland (17), Spain (8) and Switzerland (2)) } \\
\text { Run-in } 2 \text { weeks on previous dose of ICS but LABA appears to have been withdrawn } \\
\text { from the } 40 \% \text { previously taking LABA? }\end{array}$ \\
\hline Participants & $\begin{array}{l}\text { Population: } 630 \text { children (4-11) years with asthma. } \\
\text { Baseline Characteristics: Mean age } 8 \text { years. } \mathrm{FEV}_{1} 92 \% \text { predicted. Concomitant inhaled } \\
\text { corticosteroids used by } 100 \% \text { of participants (mean } 450 \mathrm{mcg} / \text { day), and around } 40 \% \\
\text { had previously being taking LABA. } \\
\text { Inclusion Criteria: Outpatients aged } 4 \text { to } 11 \mathrm{yr} \text { who had been diagnosed with asthma } \\
\text { [as defined by the American Thoracic Society] for a minimum period of } 6 \text { months, to } \\
\text { have a pre-bronchodilator PEF at least } 50 \% \text { of predicted normal and received treatment } \\
\text { with an ICS (any brand) for at least } 3 \text { months before entry into the study, with the } \\
\text { dose remaining constant ( } 375 \text { to } 1000 \mu \text { day) during the } 30 \text { days immediately prior } \\
\text { to enrolment, had to have a history of an average of more than } 1 \text { clinically important } \\
\text { exercise-induced bronchoconstriction per week during the } 3 \text { months leading up to the } \\
\text { study. } \\
\text { Exclusion Criteria: used oral, parenteral or rectal corticosteroids within } 30 \text { days of } \\
\text { inclusion in the study; any respiratory infection affecting asthma control within the } \\
30 \text { days before enrolment; any significant disease or concomitant disorder; known or } \\
\text { suspected hypersensitivity to the study medication or inhaled lactose. The use of inhaled } \\
\text { anticholinergics, beta-blockers (including eye drops), xanthines and other anti-asthma } \\
\text { products was not permitted during the study }\end{array}$ \\
\hline
\end{tabular}

\begin{tabular}{|c|c|c|}
\hline Outcomes & \multicolumn{2}{|c|}{$\begin{array}{l}\text { The primary efficacy variable was the change from baseline to treatment (average of the } \\
\text { 12-wk treatment period) in morning peak expiratory flow (PEF) } \\
\text { Paper reports: "Serious adverse events were experienced by a total of } 11 \text { patients: } 3 \text { BDF } \\
\text { (fracture, laryngitis, torticollis), } 5 \text { with budesonide and formoterol in separate inhalers } \\
\text { (appendicitis (2), vomiting, laryngitis, pneumonia) and } 3 \text { with budesonide (gastroen- } \\
\text { teritis (2) and fracture). There were no deaths }\end{array}$} \\
\hline Notes & \multicolumn{2}{|c|}{ Sponsored by AstraZeneca } \\
\hline \multicolumn{3}{|l|}{ Risk of bias } \\
\hline Item & Authors' judgement & Description \\
\hline Adequate sequence generation? & Unclear & Not reported \\
\hline Allocation concealment? & Unclear & Not reported \\
\hline
\end{tabular}


Pohunek 2006 (Continued)

\begin{tabular}{l|ll}
\hline $\begin{array}{l}\text { Blinding? } \\
\text { All outcomes }\end{array}$ & Yes & Double blind \\
\hline $\begin{array}{l}\text { Incomplete outcome data addressed? } \\
\text { All outcomes }\end{array}$ & Yes & $592 / 630(94 \%)$ completed the study \\
\hline Free of selective reporting? & Yes & $\begin{array}{l}\text { SAE reported by treatment group and event } \\
\text { type in paper }\end{array}$ \\
\hline
\end{tabular}

\section{Price 2002}

Methods

Study Design: A randomised, double-blind, Multicentre, parallel-group study in 152 general practices in the UK and Republic of Ireland and comprising two parts (4 weeks and 24 weeks) Run-in 7 to 14 days

Population: 663 adolescents and adults $(12+$ ) years with mild to moderate asthma (part
1), 505 continued to part 2
Baseline Characteristics: Mean age 38 years. Concomitant inhaled corticosteroids used
by $67 \%$ of participants.
Inclusion Criteria: 12 years and older with a diagnosis of asthma confirmed in the
clinical record for at least 3 months. Current treatment had to include a short acting b2
agonist alone or with an inhaled corticosteroid $(<400 \mathrm{mg} /$ day beclomethasone dipropi-
onate or budesonide via pressurised metered dose inhaler, or $<200$ mg/day fluticasone
or budesonide via Turbohaler) at a constant dose for $>4$ weeks. Were required to have
experienced asthma symptoms (chest tightness, cough, wheeze, or shortness of breath)
on a minimum of 3 days in the week before enrolment into the study. Either reversibility
of peak expiratory flow (PEF)/forced expiratory volume in 1 second (FEV1) of $>12 \%$
(or $>9 \%$ of predicted normal), or a diurnal variation of $>20 \%$ on at least one day during
the run in period
Exclusion Criteria: more severe or recently unstable asthma, PEF $<50 \%$ predicted;
currently receiving (during 4 weeks before enrolment) nebulised therapy, oral corticos-
teroids, leukotriene antagonist, or long acting b2 agonist; a clinically relevant upper
respiratory tract infection in the 4 weeks leading up to enrolment, irreversible chronic
airways disease

Interventions
1. Budesonide $400 \mu \mathrm{g} \mathrm{BD}+$ eformoterol $9 \mu \mathrm{g} \mathrm{BD}$
2. Budesonide $400 \mu \mathrm{g} \mathrm{BD}+$ placebo
Data from Part 2 used following 4 weeks stabilisation of patients on the same treatments
in part 1. DPI delivery

Outcomes

In part II the primary outcome measure was time to the first mild asthma exacerbation SAE data not reported in paper but obtained from Jaeschke 2008.

Notes Supported by grant from AstraZeneca

Risk of bias 
Price 2002 (Continued)

\begin{tabular}{l|l|l}
\hline Adequate sequence generation? & Yes & $\begin{array}{l}\text { Computer generated random numbers (Ni } \\
\text { Chroinin 2005) }\end{array}$ \\
\hline $\begin{array}{l}\text { Allocation concealment? } \\
\text { Blinding? }\end{array}$ & Yes & $\begin{array}{l}\text { Numbered coded solutions supplied by } \\
\text { pharmacy (Ni Chroinin 2005) }\end{array}$ \\
\hline $\begin{array}{l}\text { Incomplete outcome data addressed? } \\
\text { All outcomes }\end{array}$ & Yes & Double blind \\
\hline \begin{tabular}{l} 
Free of selective reporting? \\
\hline
\end{tabular} & Yes & 400/505 (79\%) completed part 2 \\
\hline
\end{tabular}

\section{SD-039-0714}

$\begin{array}{ll}\text { Methods } & \text { A randomized, double-blind, multicentre, parallel-group study over } 12 \text { weeks from } \\ \text { August } 2001 \text { to September } 2002 \text { at } 122 \text { centres in the United Kingdom. (119 general } \\ \text { practice centres and } 3 \text { hospital centres) Run-in } 2 \text { weeks on budesonide } 200 \text { mcg twice } \\ \text { daily } \\ \text { Efficacy and safety of budesonide/formoterol Turbuhaler }(160 / 4.5 \mathrm{mg} \text { b.i.d. delivered } \\ \text { dose) compared to budesonide Turbuhaler }{ }^{\circledR}(200 \mathrm{mg} \text { b.i.d. metered dose) in steroid-us- } \\ \text { ing asthmatic adolescent patients. A double-blind, double dummy, randomised, parallel } \\ \text { group, phase III, multicentre study. (ATTAIN STUDY) }\end{array}$

Participants

Population: 271 steroid-using asthmatic adolescents(11 to 17$)$ years.

Baseline Characteristics: Mean age 14 years. FEV $_{1} 75 \%$ predicted. Concomitant inhaled corticosteroids used by $100 \%$ of participants (.

Inclusion Criteria: $12-17$ years old, . $\mathrm{FEV}_{1} \%$ predicted $40-90 \%$, bronchodilator reversibility of at least $12 \%$ in $\mathrm{FEV}_{1}$ and experiencing asthma symptoms. Receiving an iGCS for perennial asthma, dose of iGCS within or equal to 375-1000 mg daily dose within the licensed dose for the patients' age,

Exclusion Criteria: not obvious

$\begin{array}{ll}\text { Interventions } & \text { 1. Budesonide/Formoterol 160/4.5 } \mu \mathrm{g} \text { BD } \\ \text { 2. Budesonide } 200 \mu \mathrm{g} \mathrm{BD} \\ \text { Delivery was DPI }\end{array}$

Outcomes

am PEF as recorded daily by patients in diary.

Web report indicates no deaths and one SAE in each group (overdose on BDF and bronchospasm on budesonide)

Notes Sponsored by AstraZeneca

\section{Risk of bias}

Item

Authors' judgement

Description 
SD-039-0714 (Continued)

\begin{tabular}{l|l|l}
\hline Adequate sequence generation? & Unclear & Not reported \\
\hline Allocation concealment? & Unclear & Not reported \\
\hline $\begin{array}{l}\text { Blinding? } \\
\text { All outcomes }\end{array}$ & Yes & Double blind \\
\hline $\begin{array}{l}\text { Incomplete outcome data addressed? } \\
\text { All outcomes }\end{array}$ & Yes & 219/271 (81\%) completed the study \\
\hline \begin{tabular}{l} 
Free of selective reporting? \\
\hline
\end{tabular} & Yes & SAE data in web report \\
\hline
\end{tabular}

\section{SD-039-0718}

Methods

Study Design: A randomized, double-blind, double-dummy, active-controlled study over 12 weeks from July 2002 to October 2003 at 52 centers in the United States. Runin 2 weeks on $100 \mathrm{mcg}$ budesonide twice daily

Participants
$\begin{aligned} & \text { Population: } 411 \text { children }(6-15) \text { with mild to moderate asthma. } \\ & \text { Baseline Characteristics: Mean age } 10 \text { years. } \mathrm{FEV}_{1} 82 \% \text { predicted. Concomitant in- } \\ & \text { haled corticosteroids used by } 100 \% \text { of participants (mean } 235 \mathrm{mcg} / \text { day). } \\ & \text { Inclusion Criteria: } 6 \text { to } 15 \text { years of age, chronically treated with a low to medium dose of } \\ & \text { inhaled corticosteroid (ICS), } \mathrm{FEV}_{1} \% \text { predicted at least } 50 \% \text { on ICS therapy, older than } \\ & 12 \text { years, bronchodilator reversibility of at least } 12 \% \text { in } \mathrm{FEV}_{1} \text { and at least } 0.20 \mathrm{~L} \text { from } \\ & \text { the pre-albuterol value within } 15-30 \text { minutes after administration of a standard dose of } \\ & \text { a fast-acting beta2-agonist (albuterol pMDI, } 2 \text { to } 4 \text { actuations }[90 \mu \mathrm{g} \text { per actuation], } \\ & \text { with or without a spacer, or after administration of up to } 2.5 \mathrm{mg} \text { nebulized albuterol). } \\ & \text { Younger than } 12 \text { years needed to show only reversibility of at least } 12 \% \text {. Alternatively, } \\ & \text { reversibility of PEF of at least } 15 \% \text {, but not more than } 50 \% \text {, could be used by any } \\ & \text { subject to meet the reversibility criterion. }\end{aligned}$

Exclusion Criteria: not obvious

\begin{tabular}{l|l}
\hline Interventions & $\begin{array}{l}\text { 1. Budesonide/Formoterol } 40 / 4.5 \mu \mathrm{g} 2 \mathrm{x} \text { BD pMDI delivery } \\
\text { 2. Budesonide } 40 \mu \mathrm{g} 2 \mathrm{x} \text { BD pMDI delivery } \\
\text { 3. Formoterol } 4.5 \mu \mathrm{g} 2 \mathrm{x} \text { BD DPI delivery } \\
\text { Arm three not used in this review }\end{array}$
\end{tabular}

Outcomes Primary efficacy variable: morning peak expiratory flow (PEF)

Web report lists no deaths and no patients with SAE in groups one or two

Notes Sponsored by AstraZeneca

\section{Risk of bias}

Item

Authors' judgement

Description 
SD-039-0718 (Continued)

\begin{tabular}{|c|c|c|}
\hline Adequate sequence generation? & Yes & $\begin{array}{l}\text { Randomization was stratified by age group } \\
\text { (children under } 8 \text { years of age versus chil- } \\
\text { dren } 8 \text { years and older) Subjects were ran- } \\
\text { domly assigned to } 1 \text { of the } 3 \text { treatment } \\
\text { groups }\end{array}$ \\
\hline Allocation concealment? & Unclear & No details \\
\hline $\begin{array}{l}\text { Blinding? } \\
\text { All outcomes }\end{array}$ & Yes & $\begin{array}{l}\text { Double-blind. Treatments were given in } \\
\text { double-dummy fashion because of the dif- } \\
\text { ference in devices }\end{array}$ \\
\hline $\begin{array}{l}\text { Incomplete outcome data addressed? } \\
\text { All outcomes }\end{array}$ & Yes & $\begin{array}{l}28 \% \text { dropout on BDF and } 35 \% \text { on budes- } \\
\text { onide (all randomised patients in safety } \\
\text { analysis and no events reported!) }\end{array}$ \\
\hline Free of selective reporting? & Yes & SAE data on web report \\
\hline
\end{tabular}

\section{SD-039-0719}

\begin{tabular}{|c|c|}
\hline Methods & $\begin{array}{l}\text { Study Design : A randomized, open-label, safety study over } 26 \text { weeks from July } 2002 \\
\text { to October } 2003 \text { at } 29 \text { centers in the United States. Run-in } 1 \text { week }\end{array}$ \\
\hline Participants & $\begin{array}{l}\text { Population: } 187 \text { children }(6-11) \text { years with ICS-dependent asthma. } \\
\text { Baseline Characteristics: Mean age } 9 \text { years. } \text { FEV }_{1} 84 \% \text { predicted. Concomitant inhaled } \\
\text { corticosteroids used by } 100 \% \text { of participants. } \\
\text { Inclusion Criteria: } 6 \text { to under } 12 \text { years of age with ICS-dependent asthma. FEV } 1 \% \\
\text { predicted at least } 50 \% \text {, documented historic peak expiratory flow (PEF) or FEV1 re- } \\
\text { versibility at least } 12 \% \text { from a pre-albuterol value within } 15 \text { to } 30 \text { minutes after admin- } \\
\text { istration of a standard dose of fast-acting } B_{2} \text {-agonist. Subjects without a documented } \\
\text { history of reversibility must have demonstrated } \mathrm{FEV}_{1} \text { reversibility as above at any time } \\
\text { before Visit } 2 \text {. } \\
\text { Exclusion Criteria: not obvious }\end{array}$ \\
\hline Interventions & $\begin{array}{l}\text { 1. Budesonide/Formoterol } 160 / 4.5 \mu \mathrm{g} 2 \mathrm{x} \text { BD pMDI delivery } \\
\text { 2. Budesonide } 160 \mu \mathrm{g} 2 \mathrm{x} \text { BD TBH delivery }\end{array}$ \\
\hline
\end{tabular}

Outcomes

Outcome: No single variable was considered to be primary. The primary objective of the study was to assess long-term safety

Web report indicates no deaths. Two SAEs in BDF group (asthma and pneumonia) and one on budesonide (sickle cell anaemia)

\begin{tabular}{ll}
\hline Notes & Sponsored by AstraZeneca
\end{tabular}

\section{Risk of bias}

Item

Authors' judgement

Description 
SD-039-0719 (Continued)

\begin{tabular}{l|ll}
\hline Adequate sequence generation? & Unclear & Not reported \\
\hline Allocation concealment? & Unclear & Not reported \\
\hline $\begin{array}{l}\text { Blinding? } \\
\text { All outcomes }\end{array}$ & No & Open \\
\hline $\begin{array}{l}\text { Incomplete outcome data addressed? } \\
\text { All outcomes }\end{array}$ & Yes & $87 \%$ completed the study \\
\hline Free of selective reporting? & Yes & SAE reported fully \\
\hline
\end{tabular}

\section{SD-039-0725}

Methods

Participants
Study Design: A randomized, double-blind, double-dummy, multicenter, active-controlled, parallel group, study over 12 weeks from January 2003 to August 2004 at 128 centers in the United States. Run-in 4-5 week single-blind (in which participants had to be stable on budesonide/formoterol 40/4.5 mcg two puffs twice daily)

A Twelve-Week, Randomized, Double-blind, Double-Dummy, Active-Controlled Study of SYMBICORT® pMDI Administered Once Daily in Children and Adolescents 6 to 15 Years of Age with Asthma
Population: 522 children and adolescents $(6-15)$ years with asthma.

Baseline Characteristics: Mean age 10 years. $\mathrm{FEV}_{1} 78 \%$ predicted. Concomitant inhaled corticosteroids previously used by $100 \%$ of participants (mean $245 \mathrm{mcg} / \mathrm{day}$ )

Inclusion Criteria: 6 to 15 years with a documented clinical diagnosis of asthma for at least 6 months prior to screening, and in stable condition. Should have received maintenance asthma treatment with inhaled corticosteroids (ICS) for at least 4 weeks prior to the screening visit. $\mathrm{FEV}_{1} \%$ predicted of between $60 \%-90 \%$, measured approximately 24 hours after the last dose of long-acting $\mathrm{B}_{2}$ - agonist and 6 hours after the last dose of short-acting $\mathrm{B}_{2}$-agonist. Subjects with an $\mathrm{FEV}_{1}$ predicted between $90-95 \%$ predicted could be included if they had an $\mathrm{FEV}_{1} / \mathrm{FVC}$ ratio measured on screening spirometry of less than $80 \%$. Bronchodilator reversibility of at least $12 \%$ in $\mathrm{FEV}_{1}$ and at least $0.20 \mathrm{~L}$ from baseline within 15 to 30 minutes after administration of a standard dose of fastacting ?2-agonist, except for subjects under 11 years of age, who were required to show reversibility of at least $12 \%$, but not also a change of at least $0.20 \mathrm{~L}$.

Exclusion Criteria: not stated

1. Budesonide/Formoterol 80/4.5 $\mu \mathrm{g} 2 \mathrm{x}$ QD

2. Budesonide/Formoterol 40/4.5 $\mu \mathrm{g}$ 2x BD

3. Budesonide $80 \mu \mathrm{g} 2 \mathrm{x}$ QD

Delivery was pMDI. All groups had 160 mcg budesonide daily.
Primary variable: evening PEF (from daily diary)

"There were no deaths at any time during the study."

"6 subjects had an SAE during the double blind treatment period: 2 on BDF 40 bd (abdominal pain, asthma), 3 in BDF 80 qd group (influenza, asthma -2), and one in the budesonide group (asthma)." 
SD-039-0725 (Continued)

\begin{tabular}{|c|c|c|}
\hline Notes & \multicolumn{2}{|c|}{ Sponsored by AstraZeneca } \\
\hline \multicolumn{3}{|l|}{ Risk of bias } \\
\hline Item & Authors' judgement & Description \\
\hline Adequate sequence generation? & Unclear & $\begin{array}{l}\text { Randomization was stratified by age ( } 6 \text { to } \\
11 \text { years of age versus } 12 \text { to } 15 \text { years of age) } \\
\text { at the time of screening, to ensure an ap- } \\
\text { proximately uniform distribution of sub- } \\
\text { jects across treatment groups within each } \\
\text { of these } 2 \text { strata }\end{array}$ \\
\hline Allocation concealment? & Unclear & No details \\
\hline $\begin{array}{l}\text { Blinding? } \\
\text { All outcomes }\end{array}$ & Yes & $\begin{array}{l}\text { Double-blind. In order to maintain blind- } \\
\text { ing with the twice-daily dosing regimen, all } \\
\text { subjects randomized to receive once-daily } \\
\text { dosing were to receive the active treatment } \\
\text { in the evening and placebo treatment with } \\
\text { a matched device in the morning }\end{array}$ \\
\hline $\begin{array}{l}\text { Incomplete outcome data addressed? } \\
\text { All outcomes }\end{array}$ & Yes & $499 / 521(96 \%)$ completed the study \\
\hline Free of selective reporting? & Yes & $\begin{array}{l}\text { SAEs reported by treatment group and } \\
\text { cause }\end{array}$ \\
\hline
\end{tabular}

\section{SD-039-0726}

Methods

Study Design: A randomized, double-blind, double-dummy, multicenter, parallel group, placebo- and active-controlled study over 12 weeks from April 2003 to June 2004 at 151 centers in the United States. Run-in 4-5 week single-blind

A Twelve-Week, Randomized, Double-Blind, Double-Dummy, Placebo- and ActiveControlled Study of SYMBICORT® pMDI Administered Once Daily in Adults and Adolescents with Asthma

Participants

Population: 752 adolescents and adults (16 -79) years with asthma.

Baseline Characteristics: Mean age 38 years. $\mathrm{FEV}_{1} 75 \%$ predicted. Concomitant inhaled corticosteroids used by $100 \%$ of participants.

Inclusion Criteria: 16-years of age and older, with a documented clinical diagnosis of asthma for at least 6 months prior to screening, and in stable condition. Received maintenance asthma treatment with a low to medium dose of inhaled corticosteroids (ICS) for at least 4 weeks prior to the screening visit

$\mathrm{FEV}_{1} \%$ predicted of between $60 \%-90 \%$, measured at least 24 hours after the last dose of long-acting $\mathrm{B}_{2}$ - agonist and 6 hours after the last dose of short-acting $\mathrm{B}_{2}$-agonist.

Exclusion Criteria: not obvious 


\begin{tabular}{l|l}
\hline Interventions & $\begin{array}{l}\text { 1. Budesonide/Formoterol 160/4.5 } \mu \mathrm{g} 2 \mathrm{x} \text { QD } \\
\text { 2. Budesonide/Formoterol } 80 / 4.5 \mu \mathrm{g} 2 \mathrm{x} \mathrm{QD}\end{array}$ \\
& $\begin{array}{l}\text { 3. Budesonide/Formoterol } 80 / 4.5 \mu \mathrm{g} 2 \mathrm{x} \mathrm{BD} \\
\text { 4. Budesonide } 160 \mu \mathrm{g} 2 \mathrm{x} \text { QD } \\
\text { Placebo arm and arm two not used in this analysis. MDI delivery }\end{array}$ \\
\hline Outcomes & $\begin{array}{l}\text { Primary variable: evening PEF (from daily diary) } \\
\text { SAE data obtained from web report. Five patients suffered an SAE: Three on BDF 80 } \\
\text { bd (breast cancer in situ, road traffic accident, musculoskeletal chest pain), one on BDF } \\
160 \text { daily (prostate cancer), and one on budesonide (tension headache). There were no } \\
\text { deaths }\end{array}$ \\
\hline Notes & Sponsored by AstraZeneca \\
\hline
\end{tabular}

\section{Risk of bias}

\begin{tabular}{lll}
\hline Item & Authors' judgement & Description \\
\hline Adequate sequence generation? & Unclear & Not reported \\
\hline Allocation concealment? & Unclear & Not reported \\
\hline $\begin{array}{l}\text { Blinding? } \\
\text { All outcomes }\end{array}$ & Yes & Double blind \\
\hline $\begin{array}{l}\text { Incomplete outcome data addressed? } \\
\text { All outcomes }\end{array}$ & Yes & $707 / 751$ (94\%) completed the study \\
\hline Free of selective reporting? & Yes & SAE data on web report \\
\hline
\end{tabular}

Tal 2002

Methods

Participants
Study Design: A randomized, double-blind, double-dummy, active-controlled, multicentre, parallel-group study over 12 weeks from November 1998 to June 1999 at 48 centres in 7 countries Hungary (6), the Czech Republic (7), the United Kingdom (11), Spain (7), Belgium (4), Israel (4) and South Africa (4)

Run-in 2-4 weeks on budesonide 400 mcg daily (unclear if previous LABA withdrawn)

Population: 286 children (4-17) years with asthma.

Baseline Characteristics: Mean age 11 years. $\mathrm{FEV}_{1} 75 \%$ predicted. Concomitant inhaled corticosteroids used by $100 \%$ of participants (mean $548 \mathrm{mcg} /$ day), previous LABA use not reported

Inclusion Criteria: Between 4 to 17 years of age with a diagnosis of asthma (minimum duration, 6 months), $\mathrm{FEV}_{1} \%$ predicted of 40 to $90 \%$, bronchodilator reversibility by an increase of at least $15 \%$ in $\mathrm{FEV}_{1}$ over baseline within 15 min of inhalation of a shortacting b2-agonist.

Exclusion Criteria: unstable asthma (defined as the use of oral, parenteral, or rectal corticosteroids within 30 days of study commencement), any respiratory infection af- 
fecting disease control within the previous 4 weeks, and known hypersensitivity to study medication or inhaled lactose

\begin{tabular}{l|l} 
Interventions & $\begin{array}{l}\text { 1. Budesonide/Formoterol } 80 / 4.5 \mu \mathrm{g} 2 \mathrm{x} \text { BD } \\
\text { 2. Budesonide } 100 \mu \mathrm{g} 2 \mathrm{xBD} \\
\text { Delivery was DPI }\end{array}$ \\
\hline Outcomes & $\begin{array}{l}\text { The primary efficacy variable was the change in morning PEF from baseline to end of } \\
\text { treatment } \\
\text { "A total of } 7 \text { patients in the budesonide/formoterol group had a serious adverse event } \\
\text { requiring admission to hospital (asthma (5), larynx edema (1), pneumonia (1)." Deaths } \\
\text { are not mentioned nor are any events in the budesonide group. Further clarification } \\
\text { was sought from the sponsors, who have confirmed no serious adverse events in the } \\
\text { budesonide group }\end{array}$ \\
\hline Notes & Sponsored by AstraZeneca \\
\hline
\end{tabular}

\section{Risk of bias}

\begin{tabular}{lll}
\hline Item & Authors' judgement & Description \\
\hline Adequate sequence generation? & Yes & $\begin{array}{l}\text { computer-generated block-randomization } \\
\text { list }\end{array}$ \\
\hline $\begin{array}{l}\text { Allocation concealment? } \\
\text { Blinding? }\end{array}$ & Unclear & $\begin{array}{l}\text { individual treatment code envelopes pro- } \\
\text { vided for each subject }\end{array}$ \\
\hline $\begin{array}{l}\text { All outcomes } \\
\text { All outcomes }\end{array}$ & Yes & Double-blind, double-dummy technique \\
\hline $\begin{array}{l}\text { Free of selective reporting? } \\
\text { Yes outcome data addressed? }\end{array}$ & Yes & 268/286 (94\%) completed the study \\
\hline
\end{tabular}

\section{Zetterstrom 2001}

Methods
Study Design: A randomized, double-blind, double-dummy, active-controlled, parallelgroup study over 12 weeks at 63 centres in 6 countries (Finland (7), Germany (12), Ireland (6), Norway (12), Spain (11) and Sweden (15))

Run-in 2 weeks on usual inhaled corticosteroid (no mention of continuing previous LABA)

\footnotetext{
Participants

Population: 362adults $(18-78)$ years with asthma not controlled with inhaled corticosteroids alone

Baseline Characteristics: Mean age 47 years. $\mathrm{FEV}_{1} 74 \%$ predicted. Concomitant inhaled corticosteroids used by $100 \%$ of participants (mean dose $960 \mathrm{mcg} /$ day).

Inclusion Criteria: 18 years and older, using inhaled glucocorticosteroids at a constant
} 


\begin{tabular}{|c|c|c|}
\hline & \multicolumn{2}{|c|}{$\begin{array}{l}\text { daily dose of at least } 500 \mu \mathrm{g} \text { for at least } 30 \text { days before entry, } \mathrm{FEV}_{1} \% \text { predicted of } 50 \text { ? } \\
90 \% \text {, bronchodilator reversibility by an increase of at least } 15 \% \text { in } \mathrm{FEV}_{1} \text { over baseline } \\
\text { after inhalation of terbutaline sulphate } 1 \mathrm{mg} \text { (Bricanyl Turbuhaler) or salbutamol } 0.4 \\
\mathrm{mg} \text {. } \\
\text { Exclusion Criteria: use of oral, parenteral or rectal glucocorticosteroids within } 30 \text { days } \\
\text { before study entry; respiratory infection; seasonal asthma; severe cardiovascular disorder; } \\
\text { beta-blocker therapy; a history of heavy smoking (greater than } 10 \text { pack-yrs); pregnancy } \\
\text { or failure to use acceptable contraceptives in women of childbearing potential }\end{array}$} \\
\hline Interventions & \multicolumn{2}{|c|}{$\begin{array}{l}\text { 1. Budesonide/Formoterol } 160 / 4.5 \mu \mathrm{g} 2 \mathrm{x} \mathrm{BD} \\
\text { 2. Budesonide } 200 \mu \mathrm{g}+\text { Formoterol } 4.5 \mu \mathrm{g} 2 \mathrm{x} \mathrm{BD} \\
\text { 3. Budesonide } 200 \mu \mathrm{g} 2 \mathrm{x} \text { BD } \\
\text { Delivery was DPI, equivalent to budesonide } 400 \mathrm{mcg} \text { bd metered dose in all arms }\end{array}$} \\
\hline Outcomes & \multicolumn{2}{|c|}{$\begin{array}{l}\text { The primary efficacy variable was change in average morning PEF from baseline to study } \\
\text { end } \\
\text { Paper reports: "There were five serious adverse events in the single inhaler therapy group } \\
\text { and one in the budesonide alone group. There was one death by suicide and four hos- } \\
\text { pital admissions (due to pneumonia, liver cysts, ischaemic stroke and intervertebral disc } \\
\text { prolapse)." The sponsors have confirmed that the death was on a combined budesonide/ } \\
\text { formoterol inhaler }\end{array}$} \\
\hline Notes & \multicolumn{2}{|c|}{ Sponsored by AstraZeneca } \\
\hline \multicolumn{3}{|l|}{ Risk of bias } \\
\hline Item & Authors' judgement & Description \\
\hline Adequate sequence generation? & Yes & $\begin{array}{l}\text { Computerized randomization occurred on } \\
\text { a per country basis. }\end{array}$ \\
\hline Allocation concealment? & Yes & $\begin{array}{l}\text { individual treatment codes were kept in } \\
\text { sealed envelopes until data analysis }\end{array}$ \\
\hline $\begin{array}{l}\text { Blinding? } \\
\text { All outcomes }\end{array}$ & Yes & $\begin{array}{l}\text { Double-blind, patients successively used } \\
\text { three numbered inhalers (identical in ap- } \\
\text { pearance to the corresponding placebo) } \\
\text { each morning and evening }\end{array}$ \\
\hline $\begin{array}{l}\text { Incomplete outcome data addressed? } \\
\text { All outcomes }\end{array}$ & Yes & $309 / 362(85 \%)$ completed the study \\
\hline Free of selective reporting? & Yes & SAE by treatment group in paper. \\
\hline
\end{tabular}


Characteristics of excluded studies [ordered by study ID]

\begin{tabular}{|c|c|}
\hline Study & Reason for exclusion \\
\hline Ankerst 2003 & Short term crossover study \\
\hline AstraZeneca 2005 & Comparison with Budesonide and Theophylline \\
\hline AstraZeneca $2005 a$ & Ongoing study \\
\hline AstraZeneca 2005b & Comparison of Single Inhaler Therapy with Current Best Practice \\
\hline AstraZeneca 2005 c & Comparison of Single Inhaler Therapy with Current Best Practice \\
\hline AstraZeneca 2005d & Comparison of Single Inhaler Therapy with Current Best Practice \\
\hline AstraZeneca 2006 & Comparison of Single Inhaler Therapy with ICS and terbutaline \\
\hline AstraZeneca 2006a & Comparison of Single Inhaler Therapy with Current Best Practice \\
\hline AstraZeneca 2006b & Comparison of Single Inhaler Therapy with Current Best Practice \\
\hline Balanag 2006 & Comparison to salbutamol in acute asthma \\
\hline Bateman 2003 & BDF compared to higher dose Fluticasone \\
\hline Bateman 2006 & Acute asthma \\
\hline Bouros 1999 & Formoterol and beclometasone compared to higher dose beclometasone \\
\hline Buhl 2004 & Adjustable versus fixed dose BDF \\
\hline Burgess 1998 & Short term cross-over study \\
\hline Canonica 2004 & Adjustable versus fixed dose BDF \\
\hline Ceylan 2004 & Formoterol in comparison with montelukast in addition to low dose ICS \\
\hline Dhillon 2006 & Review of beclometasone/formoterol treatment \\
\hline FitzGerald 1999 & No randomisation to ICS \\
\hline FitzGerald 2003 & Adjustable versus fixed dose BDF \\
\hline Haahtela 2006 & Formoterol used as needed (with or without budesonide) \\
\hline Ind 2004 & Adjustable versus fixed dose BDF \\
\hline
\end{tabular}


(Continued)

\begin{tabular}{|c|c|}
\hline Kozlik-Feldmann 1996 & No randomisation to ICS \\
\hline Lalloo 2003 & BDF compared to higher dose ICS \\
\hline Leuppi 2003 & Adjustable versus fixed dose BDF \\
\hline Lotvall & Short term comparison of bronchodilation following FPS and BDF \\
\hline Lundborg 2006 & Cost effectiveness of Single inhaler therapy \\
\hline Mitchell 2003 & Comparison with higher dose ICS \\
\hline Molimard 2001 & Not randomised to ICS \\
\hline Novartis 2005 & No randomisation to ICS \\
\hline O’Byrne 2005 & BDF as single inhaler therapy or fixed dose compared to higher dose budesonide \\
\hline Overbeek 2005 & Duration of less than 12 weeks on each dose of budesonide \\
\hline Papi 2007 & Delivery device comparison for beclometasone/formoterol combination inhalers \\
\hline Pauwels 2003 & Comparison of formoterol with salbutamol as relief medication \\
\hline Pleskow 2003 & Not randomised to ICS \\
\hline Pohl 2006 & Adjustable Maintenance Dosing study \\
\hline Rabe 2006 & BDF single inhaler therapy compared to higher dose budesonide \\
\hline Rosenhall 2002 & Combined BDF inhaler compared to both medications given together in separate inhalers \\
\hline Rosenhall 2003 & Combined BDF inhaler compared to both medications given together in separate inhalers \\
\hline Rosenhall 2003a & Combined BDF inhaler compared to both medications given together in separate inhalers \\
\hline Scicchitano 2004 & BDF single inhaler therapy compared to higher dose budesonide \\
\hline Stelmach 2007 & 4 week study \\
\hline van der Molen 1997 & No randomisation to inhaled corticosteroids \\
\hline Villa, 2002 & Formoterol as needed compared to terbutaline as needed \\
\hline Von Berg 2003 & No randomisation to ICS \\
\hline Worth 2005 & Single inhaler therapy compared to current best practice \\
\hline
\end{tabular}




\section{(Continued)}

Zetterstrom 2001a

Zetterström 2000
Single inhaler therapy

Single inhaler therapy 
DATA AND ANALYSES

Comparison 1. Formoterol and ICS versus same dose ICS

\begin{tabular}{|c|c|c|c|c|}
\hline Outcome or subgroup title & $\begin{array}{l}\text { No. of } \\
\text { studies }\end{array}$ & $\begin{array}{c}\text { No. of } \\
\text { participants }\end{array}$ & Statistical method & Effect size \\
\hline 1 All-cause Mortality & 23 & 10816 & Peto Odds Ratio (Peto, Fixed, 95\% CI) & $5.83[0.78,43.77]$ \\
\hline 1.1 Adults and Adolescents & 16 & 8028 & Peto Odds Ratio (Peto, Fixed, 95\% CI) & $5.83[0.78,43.77]$ \\
\hline 1.2 Children and Adolescents & 7 & 2788 & Peto Odds Ratio (Peto, Fixed, 95\% CI) & Not estimable \\
\hline $\begin{array}{l}2 \text { All-cause non-fatal Serious } \\
\text { Adverse Events }\end{array}$ & 23 & 10816 & Peto Odds Ratio (Peto, Fixed, 95\% CI) & $1.06[0.81,1.39]$ \\
\hline 2.1 Adults and Adolescents & 16 & 8028 & Peto Odds Ratio (Peto, Fixed, 95\% CI) & $0.99[0.74,1.33]$ \\
\hline 2.2 Children and Adolescents & 7 & 2788 & Peto Odds Ratio (Peto, Fixed, 95\% CI) & $1.62[0.80,3.28]$ \\
\hline 3 Asthma Mortality & 23 & & Peto Odds Ratio (Peto, Fixed, 95\% CI) & Totals not selected \\
\hline 3.1 Adults and Adolescents & 16 & & Peto Odds Ratio (Peto, Fixed, 95\% CI) & Not estimable \\
\hline 3.2 Children and Adolescents & 7 & & Peto Odds Ratio (Peto, Fixed, 95\% CI) & Not estimable \\
\hline $\begin{array}{l}4 \text { Asthma-related non-fatal Serious } \\
\text { Adverse Events }\end{array}$ & 23 & 10816 & Peto Odds Ratio (Peto, Fixed, 95\% CI) & $0.68[0.39,1.18]$ \\
\hline 4.1 Adults and Adolescents & 16 & 8028 & Peto Odds Ratio (Peto, Fixed, 95\% CI) & $0.53[0.28,1.00]$ \\
\hline 4.2 Children and Adolescents & 7 & 2788 & Peto Odds Ratio (Peto, Fixed, 95\% CI) & $1.49[0.48,4.61]$ \\
\hline $\begin{array}{l}5 \text { All-cause Mortality (risk } \\
\text { difference) }\end{array}$ & 23 & 10816 & Risk Difference (M-H, Fixed, 95\% CI) & Not estimable \\
\hline 5.1 Adults and Adolescents & 16 & 8028 & Risk Difference (M-H, Fixed, 95\% CI) & Not estimable \\
\hline 5.2 Children and Adolescents & 7 & 2788 & Risk Difference (M-H, Fixed, 95\% CI) & Not estimable \\
\hline $\begin{array}{l}6 \text { All-cause non-fatal Serious } \\
\text { Adverse Events (risk difference) }\end{array}$ & 23 & 10816 & Risk Difference (M-H, Fixed, 95\% CI) & $0.00[-0.00,0.01]$ \\
\hline 6.1 Adults and Adolescents & 16 & 8028 & Risk Difference (M-H, Fixed, 95\% CI) & Not estimable \\
\hline 6.2 Children and Adolescents & 7 & 2788 & Risk Difference (M-H, Fixed, 95\% CI) & $0.01[-0.00,0.01]$ \\
\hline $\begin{array}{l}7 \text { Asthma-related non-fatal Serious } \\
\text { Adverse Events (risk difference) }\end{array}$ & 23 & 10816 & Risk Difference (M-H, Fixed, 95\% CI) & $-0.00[-0.01,0.00]$ \\
\hline 7.1 Adults and Adolescents & 16 & 8028 & Risk Difference (M-H, Fixed, 95\% CI) & Not estimable \\
\hline 7.2 Children and Adolescents & 7 & 2788 & Risk Difference (M-H, Fixed, 95\% CI) & $0.00[-0.00,0.01]$ \\
\hline $\begin{array}{l}8 \text { All-cause Mortality } \\
\quad \text { (Mantel-Haenszel fixed) }\end{array}$ & 23 & 10816 & Odds Ratio (M-H, Fixed, 95\% CI) & $2.15[0.43,10.67]$ \\
\hline 8.1 Adults and Adolescents & 16 & 8028 & Odds Ratio (M-H, Fixed, 95\% CI) & $2.15[0.43,10.67]$ \\
\hline 8.2 Children and Adolescents & 7 & 2788 & Odds Ratio (M-H, Fixed, 95\% CI) & Not estimable \\
\hline $\begin{array}{l}9 \text { All-cause non-fatal } \\
\text { Serious Adverse Events } \\
\text { (Mantel-Haenszel fixed) }\end{array}$ & 23 & 10816 & Odds Ratio (M-H, Fixed, 95\% CI) & $1.06[0.81,1.38]$ \\
\hline 9.1 Adults and Adolescents & 16 & 8028 & Odds Ratio (M-H, Fixed, 95\% CI) & $0.98[0.74,1.31]$ \\
\hline 9.2 Children and Adolescents & 7 & 2788 & Odds Ratio (M-H, Fixed, 95\% CI) & $1.62[0.77,3.38]$ \\
\hline $\begin{array}{l}10 \text { All-cause non-fatal Serious } \\
\text { Adverse Events (sensitivity } \\
\text { analysis without unblinded } \\
\text { study) }\end{array}$ & 22 & 10630 & Peto Odds Ratio (Peto, Fixed, 95\% CI) & $1.06[0.81,1.40]$ \\
\hline 10.1 Adults and Adolescents & 16 & 8028 & Peto Odds Ratio (Peto, Fixed, 95\% CI) & $0.99[0.74,1.33]$ \\
\hline 10.2 Children and Adolescents & 6 & 2602 & Peto Odds Ratio (Peto, Fixed, 95\% CI) & $1.69[0.81,3.54]$ \\
\hline
\end{tabular}




\section{Analysis I.I. Comparison I Formoterol and ICS versus same dose ICS, Outcome I All-cause Mortality.}

Review: Regular treatment with formoterol and inhaled steroids for chronic asthma: serious adverse events

Comparison: I Formoterol and ICS versus same dose ICS

Outcome: I All-cause Mortality

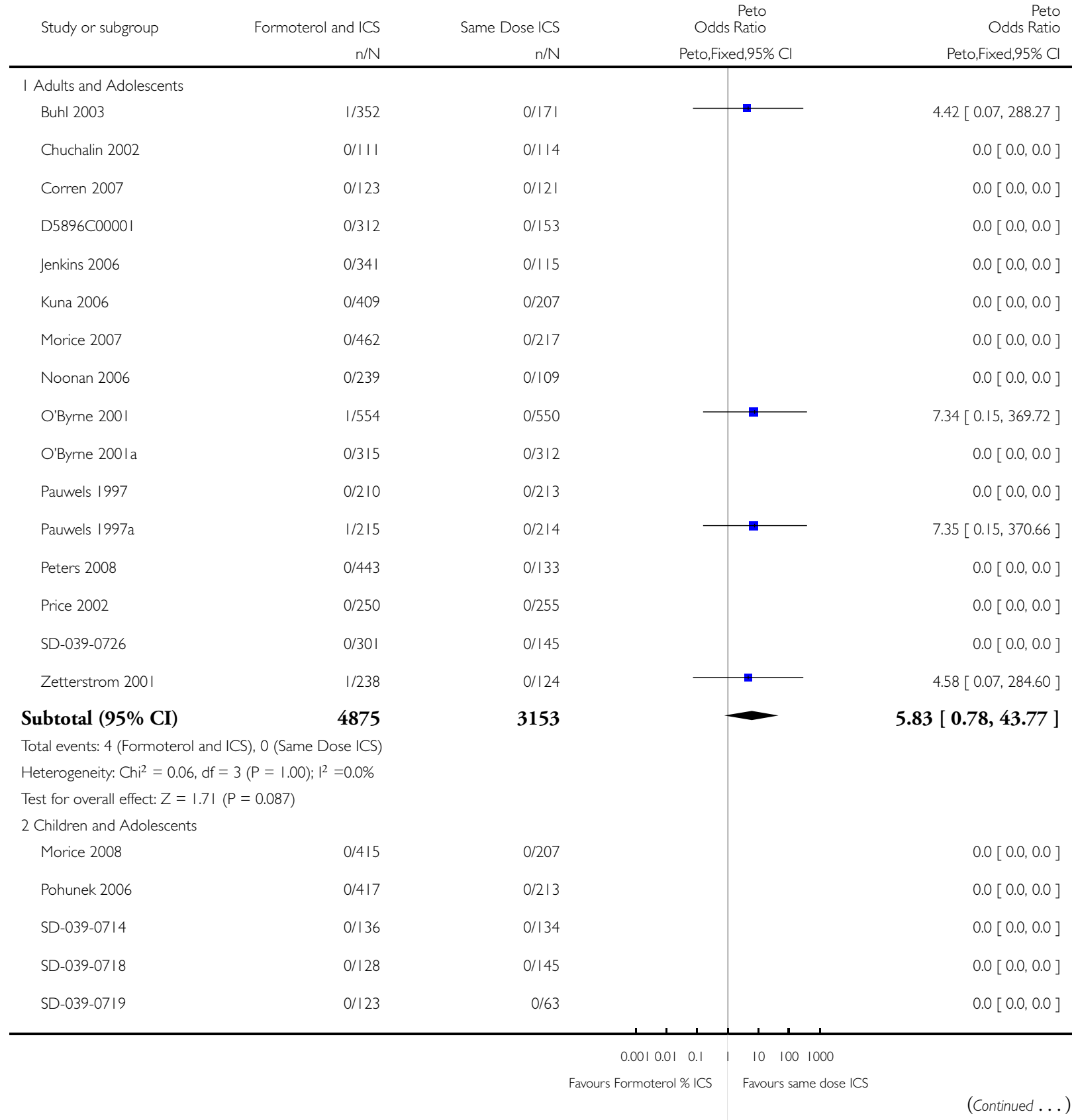




\begin{tabular}{|c|c|c|c|c|}
\hline \multirow[t]{2}{*}{ Study or subgroup } & Formoterol and ICS & Same Dose ICS & $\begin{array}{r}\text { Peto } \\
\text { Odds Ratio }\end{array}$ & $\begin{array}{c}\text { (... Continued) } \\
\text { Peto } \\
\text { Odds Ratio } \\
\text { Peto.Fixed } 95 \% \text { C }\end{array}$ \\
\hline & 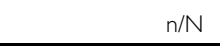 & $n / N$ & Peto,Fixed,95\% Cl & Peto,Fixed,95\% Cl \\
\hline SD-039-0725 & $0 / 352$ & 0/169 & & $0.0[0.0,0.0]$ \\
\hline Tal 2002 & $0 / 148$ & $0 / 138$ & & $0.0[0.0,0.0]$ \\
\hline Subtotal $(95 \% \mathrm{CI})$ & 1719 & 1069 & & $0.0[0.0,0.0]$ \\
\hline \multicolumn{5}{|c|}{ Total events: 0 (Formoterol and ICS), 0 (Same Dose ICS) } \\
\hline \multicolumn{5}{|c|}{ Heterogeneity: $\mathrm{Chi}^{2}=0.0, \mathrm{df}=0(\mathrm{P}<0.0000 \mathrm{I}) ; \mathrm{I}^{2}=0.0 \%$} \\
\hline \multicolumn{5}{|c|}{ Test for overall effect: $Z=0.0(P<0.0000 \mathrm{I})$} \\
\hline Total $(95 \% \mathrm{CI})$ & 6594 & 4222 & - & $5.83[0.78,43.77]$ \\
\hline \multicolumn{5}{|c|}{ Total events: 4 (Formoterol and ICS), 0 (Same Dose ICS) } \\
\hline \multicolumn{5}{|c|}{ Heterogeneity: Chi $^{2}=0.06, d f=3(P=1.00) ; 1^{2}=0.0 \%$} \\
\hline \multicolumn{5}{|c|}{ Test for overall effect: $Z=1.7 \mid(P=0.087)$} \\
\hline \multicolumn{5}{|c|}{ Test for subgroup differences: Not applicable } \\
\hline
\end{tabular}

Analysis I.2. Comparison I Formoterol and ICS versus same dose ICS, Outcome 2 All-cause non-fatal Serious Adverse Events.

Review: Regular treatment with formoterol and inhaled steroids for chronic asthma: serious adverse events

Comparison: I Formoterol and ICS versus same dose ICS

Outcome: 2 All-cause non-fatal Serious Adverse Events

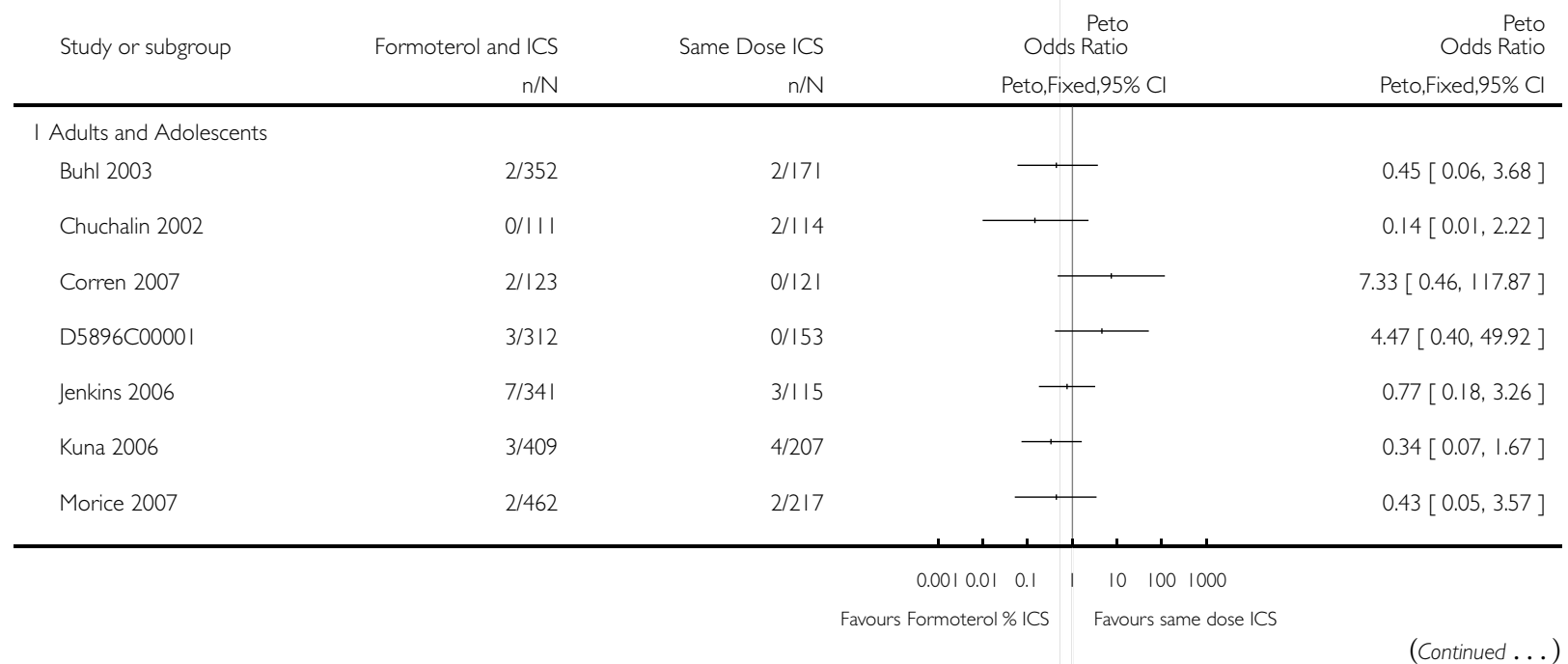




\begin{tabular}{|c|c|c|c|c|}
\hline \multirow[t]{2}{*}{ Study or subgroup } & Formoterol and ICS & Same Dose ICS & $\begin{array}{r}\text { Peto } \\
\text { Odds Ratio }\end{array}$ & $\begin{array}{r}\text { (... Continued) } \\
\text { Peto } \\
\text { Odds Ratio }\end{array}$ \\
\hline & $\mathrm{n} / \mathrm{N}$ & $n / N$ & Peto,Fixed,95\% Cl & Peto,Fixed,95\% Cl \\
\hline Noonan 2006 & $7 / 239$ & 0/109 & $\square$ & $4.40[0.88,22.04]$ \\
\hline O'Byrne 2001 & $20 / 554$ & $23 / 550$ & $=$ & $0.86[0.47,1.58]$ \\
\hline O'Byrne 200 la & $15 / 315$ & $19 / 312$ & 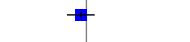 & $0.77[0.39,1.54]$ \\
\hline Pauwels 1997 & $10 / 210$ & $9 / 213$ & - & $1.13[0.45,2.84]$ \\
\hline Pauwels 1997a & $15 / 215$ & $12 / 214$ & $\mp$ & $1.26[0.58,2.75]$ \\
\hline Peters 2008 & $21 / 443$ & $5 / 133$ & $=$ & $1.26[0.49,3.19]$ \\
\hline Price 2002 & 2/250 & $3 / 255$ & + & $0.68[0.12,3.96]$ \\
\hline SD-039-0726 & $4 / 301$ & $1 / 145$ & 7 & $1.78[0.27,11.65]$ \\
\hline Zetterstrom 2001 & $3 / 238$ & 1/124 & ' & $1.51[0.19,12.04]$ \\
\hline Subtotal $(95 \%$ CI) & 4875 & 3153 & $\cdot$ & $0.99[0.74,1.33]$ \\
\hline \multicolumn{5}{|c|}{ Total events: I I 6 (Formoterol and ICS), 86 (Same Dose ICS) } \\
\hline \multicolumn{5}{|c|}{ Heterogeneity: $\mathrm{Chi}^{2}=13.79, \mathrm{df}=15(P=0.54) ; 1^{2}=0.0 \%$} \\
\hline \multicolumn{5}{|c|}{ Test for overall effect: $Z=0.07(P=0.95)$} \\
\hline \multicolumn{5}{|l|}{2 Children and Adolescents } \\
\hline Morice 2008 & $2 / 415$ & 3/207 & - & $0.30[0.05,1.93]$ \\
\hline Pohunek 2006 & $8 / 417$ & $3 / 213$ & - & $1.35[0.38,4.74]$ \\
\hline SD-039-07/4 & 1/136 & 1/134 & & $0.99[0.06,15.83]$ \\
\hline SD-039-07।8 & $0 / 128$ & $0 / 145$ & & $0.0[0.0,0.0]$ \\
\hline SD-039-07।9 & $2 / 123$ & 1/63 & $\bar{L}$ & $1.02[0.09,11.34]$ \\
\hline SD-039-0725 & $5 / 352$ & $1 / 169$ & 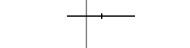 & $2.07[0.37,11.52]$ \\
\hline Tal 2002 & $7 / 148$ & $0 / 138$ & $\longrightarrow$ & $7.20[1.61,32.21]$ \\
\hline Subtotal $(95 \% \mathrm{CI})$ & 1719 & 1069 & - & $1.62[0.80,3.28]$ \\
\hline \multicolumn{5}{|c|}{ Total events: 25 (Formoterol and ICS), 9 (Same Dose ICS) } \\
\hline \multicolumn{5}{|c|}{ Heterogeneity: $C h i^{2}=7.39, d f=5(P=0.19) ; 1^{2}=32 \%$} \\
\hline \multicolumn{5}{|c|}{ Test for overall effect: $Z=1.34(P=0.18)$} \\
\hline Total $(95 \% \mathrm{CI})$ & 6594 & 4222 & $\bullet$ & $1.06[0.81,1.39]$ \\
\hline \multicolumn{5}{|c|}{ Total events: I4I (Formoterol and ICS), 95 (Same Dose ICS) } \\
\hline \multicolumn{5}{|c|}{ Heterogeneity: $\mathrm{Ch}^{2}=22.78, \mathrm{df}=21(\mathrm{P}=0.36) ; \mathrm{I}^{2}=8 \%$} \\
\hline \multicolumn{5}{|c|}{ Test for overall effect: $Z=0.45(P=0.65)$} \\
\hline Test for subgroup differen & $=1.60, \mathrm{df}=\mathrm{I}(\mathrm{P}=0.2$ & & & \\
\hline
\end{tabular}

$0.0010 .010 .1 \quad 1 \quad 10 \quad 100 \quad 1000$

Favours Formoterol \% ICS Favours same dose ICS 
Analysis I.3. Comparison I Formoterol and ICS versus same dose ICS, Outcome 3 Asthma Mortality.

Review: Regular treatment with formoterol and inhaled steroids for chronic asthma: serious adverse events

Comparison: I Formoterol and ICS versus same dose ICS

Outcome: 3 Asthma Mortality

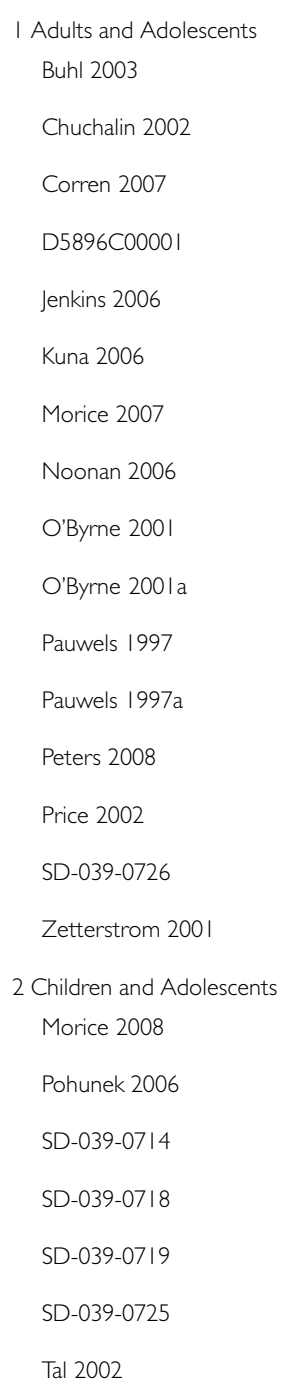

0/352

0/1 II

$0 / 123$

$0 / 312$

0/34I

0/409

0/462

0/239

|/554

$0 / 315$

$0 / 210$

$0 / 215$

0/443

0/250

0/301

$0 / 238$

$0 / 415$

0/417

$0 / 136$

$0 / 128$

$0 / 123$

0/352

$0 / 148$
$0 / 171$

$0 / 114$

$0 / 121$

0/153

$0 / 115$

0/207

0/217

0/109

0/550

$0 / 312$

$0 / 213$

$0 / 214$

$0 / 133$

0/255

0/145

$0 / 124$

0/207

$0 / 213$

0/134

0/145

$0 / 63$

$0 / 169$

0/138
$0.0[0.0,0.0]$

$0.0[0.0,0.0]$

$0.0[0.0,0.0]$

$0.0[0.0,0.0]$

$0.0[0.0,0.0]$

$0.0[0.0,0.0]$

$0.0[0.0,0.0]$

$0.0[0.0,0.0]$

$7.34[0.15,369.72]$

$0.0[0.0,0.0]$

$0.0[0.0,0.0]$

$0.0[0.0,0.0]$

$0.0[0.0,0.0]$

$0.0[0.0,0.0]$

$0.0[0.0,0.0]$

$0.0[0.0,0.0]$

$0.0[0.0,0.0]$

$0.0[0.0,0.0]$

$0.0[0.0,0.0]$

$0.0[0.0,0.0]$

$0.0[0.0,0.0]$

$0.0[0.0,0.0]$

$0.0[0.0,0.0]$ 


\section{Analysis I.4. Comparison I Formoterol and ICS versus same dose ICS, Outcome 4 Asthma-related non- fatal Serious Adverse Events.}

Review: Regular treatment with formoterol and inhaled steroids for chronic asthma: serious adverse events

Comparison: I Formoterol and ICS versus same dose ICS

Outcome: 4 Asthma-related non-fatal Serious Adverse Events

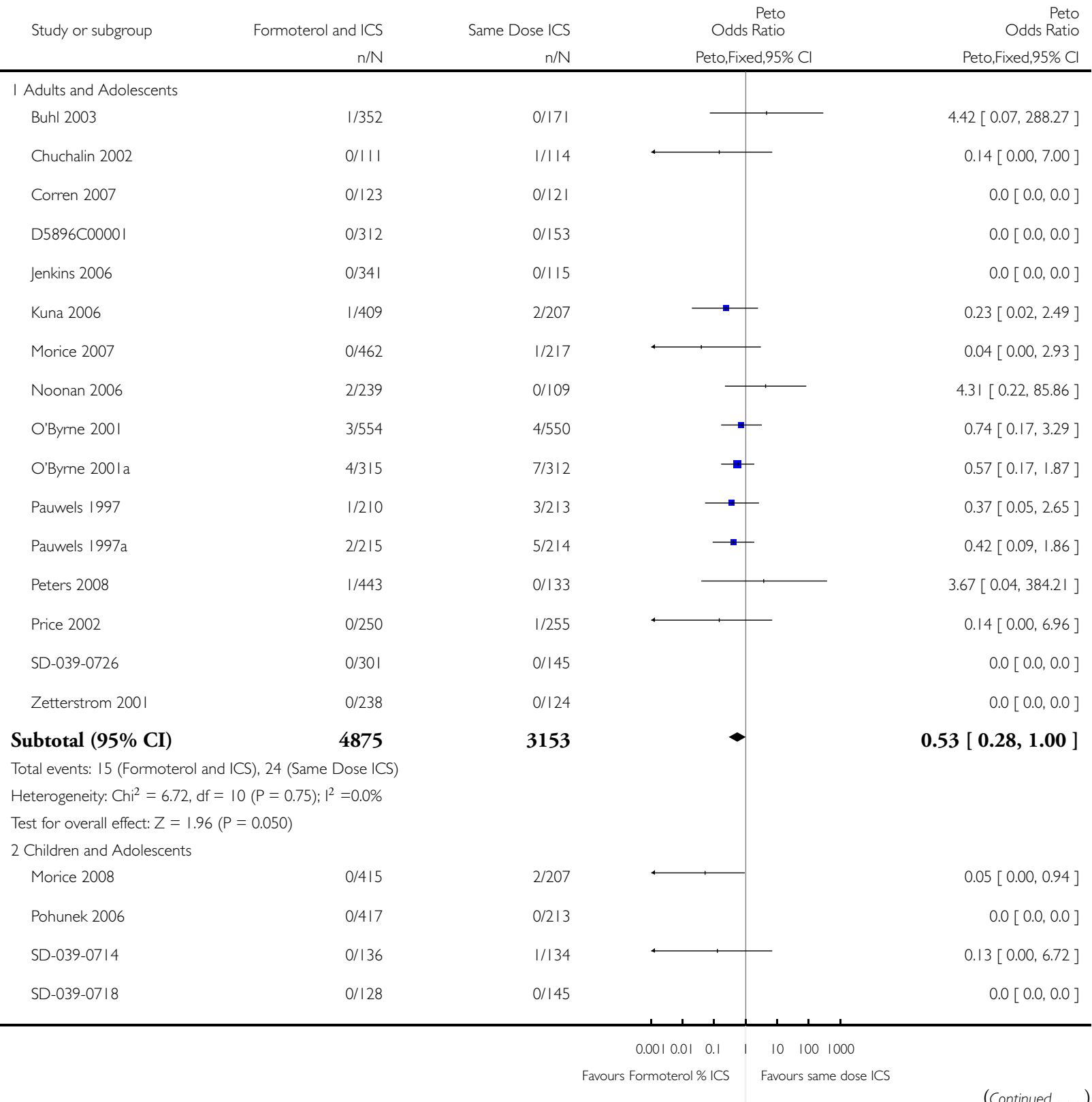




\begin{tabular}{|c|c|c|c|c|}
\hline \multirow[t]{2}{*}{ Study or subgroup } & Formoterol and ICS & Same Dose ICS & $\begin{array}{r}\text { Peto } \\
\text { Odds Ratio }\end{array}$ & (... Continued) \\
\hline & $\mathrm{n} / \mathrm{N}$ & $\mathrm{n} / \mathrm{N}$ & Peto,Fixed,95\% Cl & Peto,Fixed,95\% Cl \\
\hline SD-039-0719 & $1 / 123$ & $0 / 63$ & 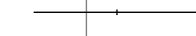 & $4.54[0.07,285.29]$ \\
\hline SD-039-0725 & $3 / 352$ & $1 / 169$ & $\square$ & $1.41[0.17,11.48]$ \\
\hline Tal 2002 & $5 / 148$ & $0 / 138$ & $\longrightarrow$ & $7.10[1.21,41.53]$ \\
\hline Subtotal $(95 \% \mathrm{CI})$ & 1719 & 1069 & - & $1.49[0.48,4.61]$ \\
\hline \multicolumn{5}{|c|}{ Total events: 9 (Formoterol and ICS), 4 (Same Dose ICS) } \\
\hline \multicolumn{5}{|c|}{ Heterogeneity: $C h i^{2}=9.89, d f=4(P=0.04) ; I^{2}=60 \%$} \\
\hline \multicolumn{5}{|c|}{ Test for overall effect: $Z=0.70(P=0.49)$} \\
\hline Total $(95 \% \mathrm{CI})$ & 6594 & 4222 & $\bullet$ & $0.68[0.39,1.18]$ \\
\hline \multicolumn{5}{|c|}{ Total events: 24 (Formoterol and ICS), 28 (Same Dose ICS) } \\
\hline \multicolumn{5}{|c|}{ Heterogeneity: $\mathrm{Chi}^{2}=19.08, \mathrm{df}=15(P=0.21) ;\left.\right|^{2}=21 \%$} \\
\hline \multicolumn{5}{|c|}{ Test for overall effect: $Z=1.36(P=0.17)$} \\
\hline \multicolumn{5}{|c|}{ Test for subgroup differences: $\mathrm{Chi}^{2}=2.48, \mathrm{df}=|(P=0.12),|^{2}=60 \%$} \\
\hline
\end{tabular}




\section{Analysis I.5. Comparison I Formoterol and ICS versus same dose ICS, Outcome 5 All-cause Mortality (risk difference).}

Review: Regular treatment with formoterol and inhaled steroids for chronic asthma: serious adverse events

Comparison: I Formoterol and ICS versus same dose ICS

Outcome: 5 All-cause Mortality (risk difference)

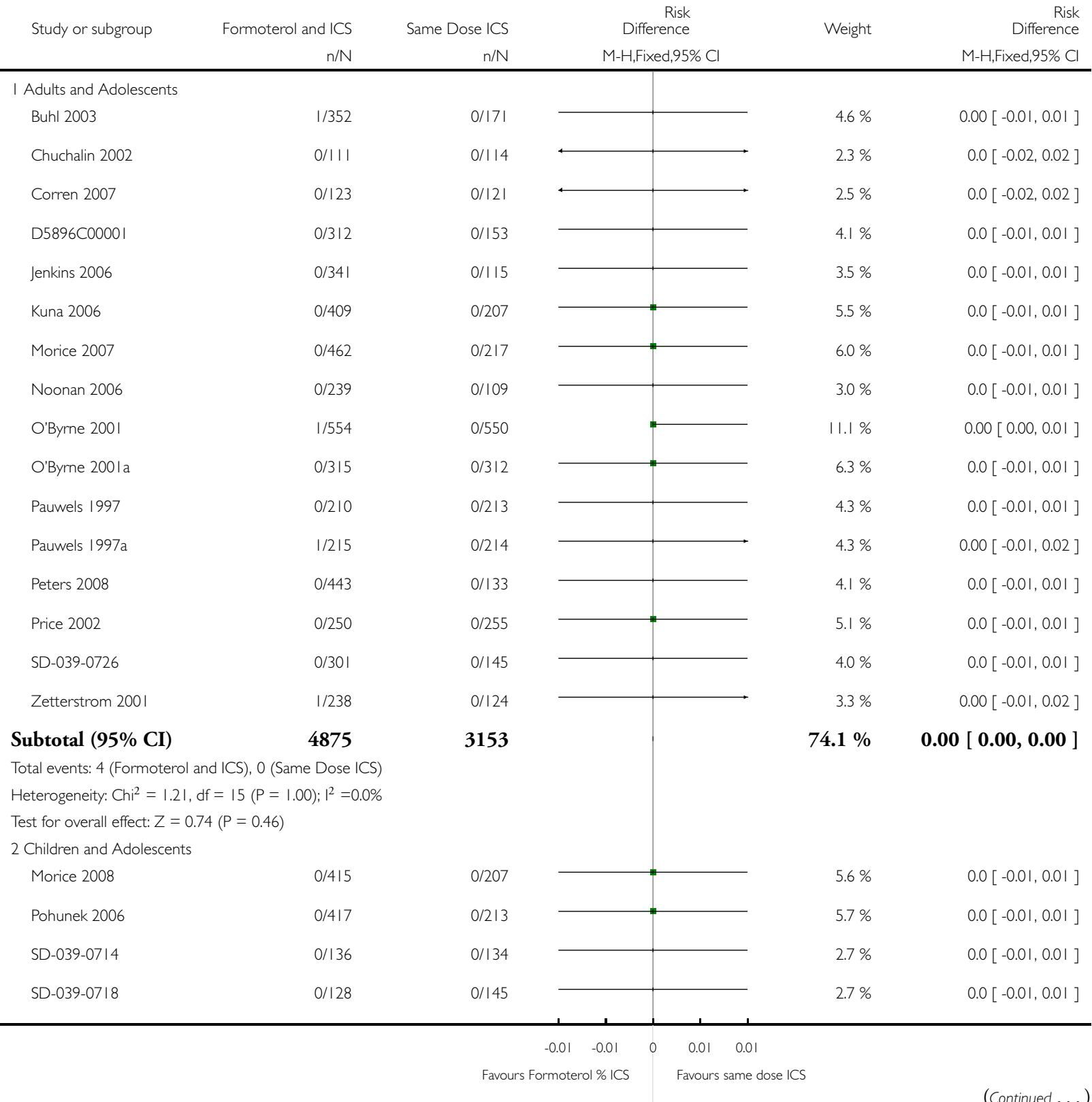


(... Continued)

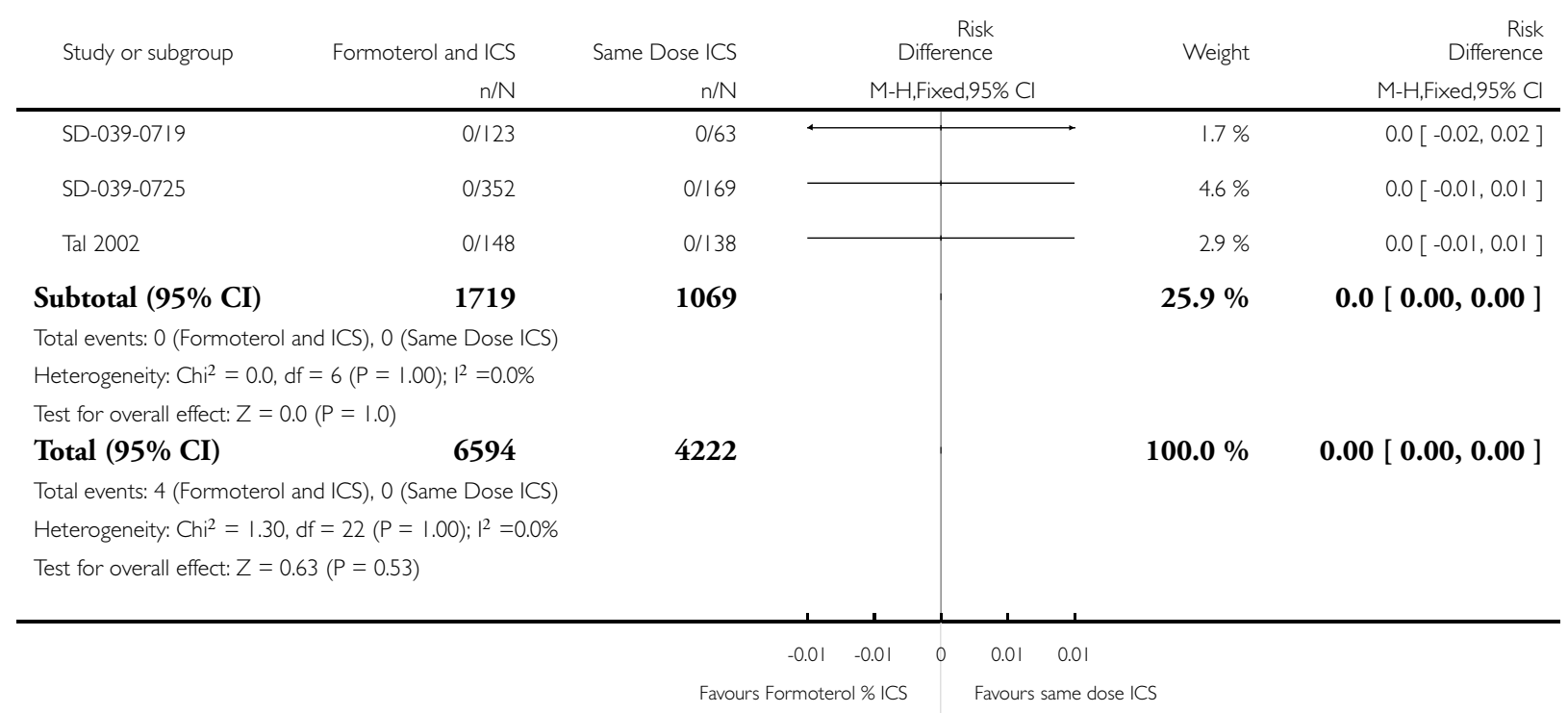


Analysis I.6. Comparison I Formoterol and ICS versus same dose ICS, Outcome 6 All-cause non-fatal Serious Adverse Events (risk difference).

Review: Regular treatment with formoterol and inhaled steroids for chronic asthma: serious adverse events

Comparison: I Formoterol and ICS versus same dose ICS

Outcome: 6 All-cause non-fatal Serious Adverse Events (risk difference)

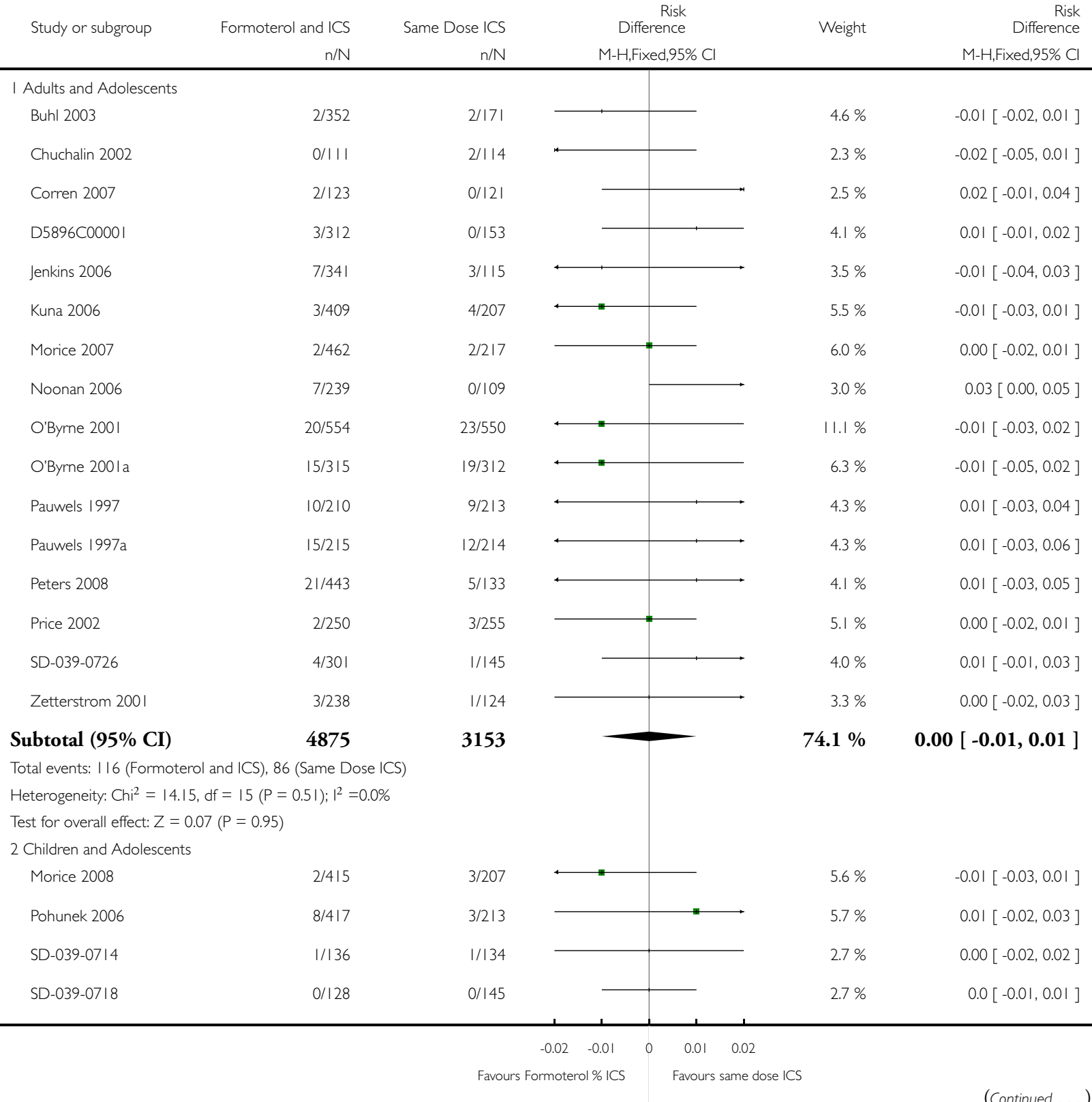


(... Continued)

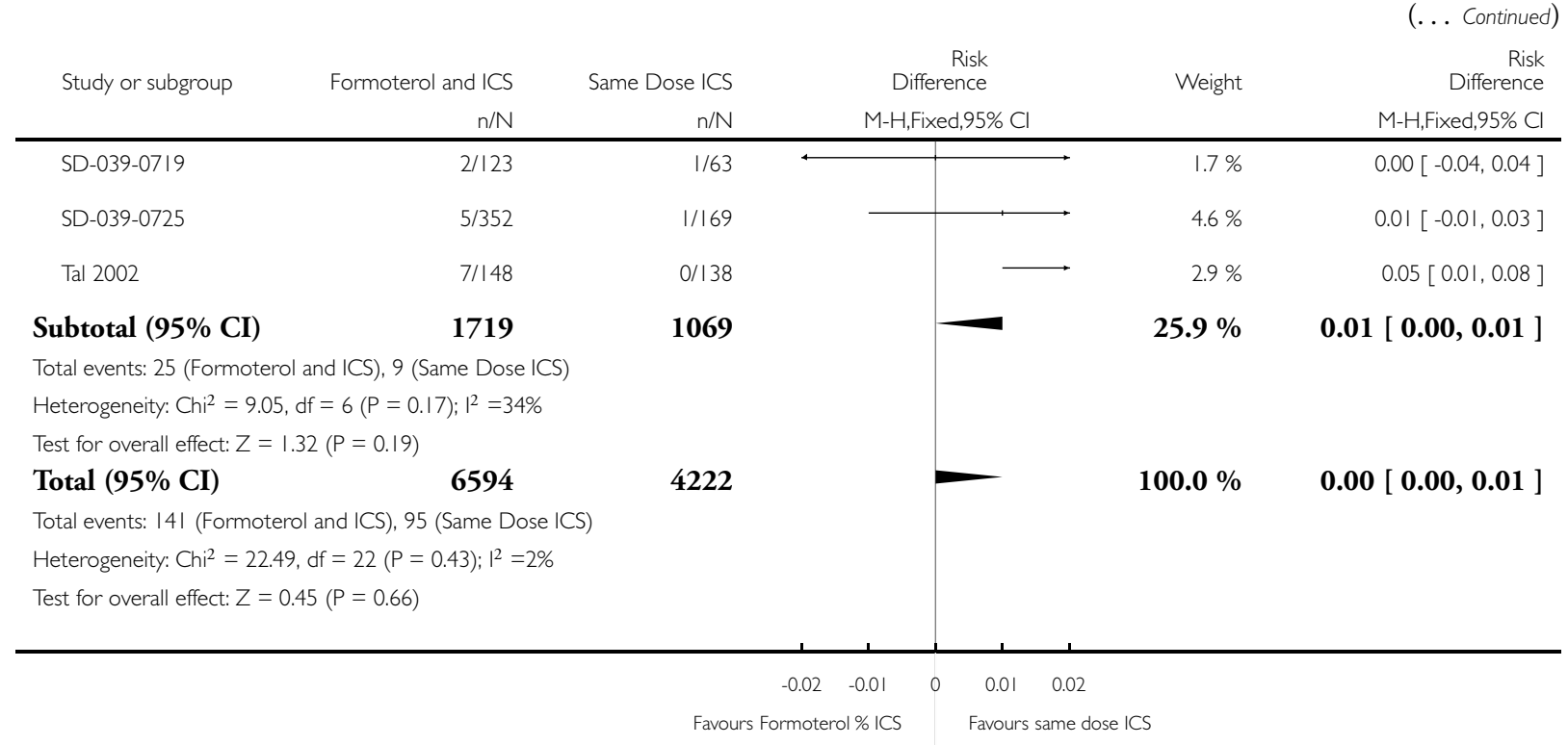


Analysis I.7. Comparison I Formoterol and ICS versus same dose ICS, Outcome 7 Asthma-related nonfatal Serious Adverse Events (risk difference).

Review: Regular treatment with formoterol and inhaled steroids for chronic asthma: serious adverse events

Comparison: I Formoterol and ICS versus same dose ICS

Outcome: 7 Asthma-related non-fatal Serious Adverse Events (risk difference)

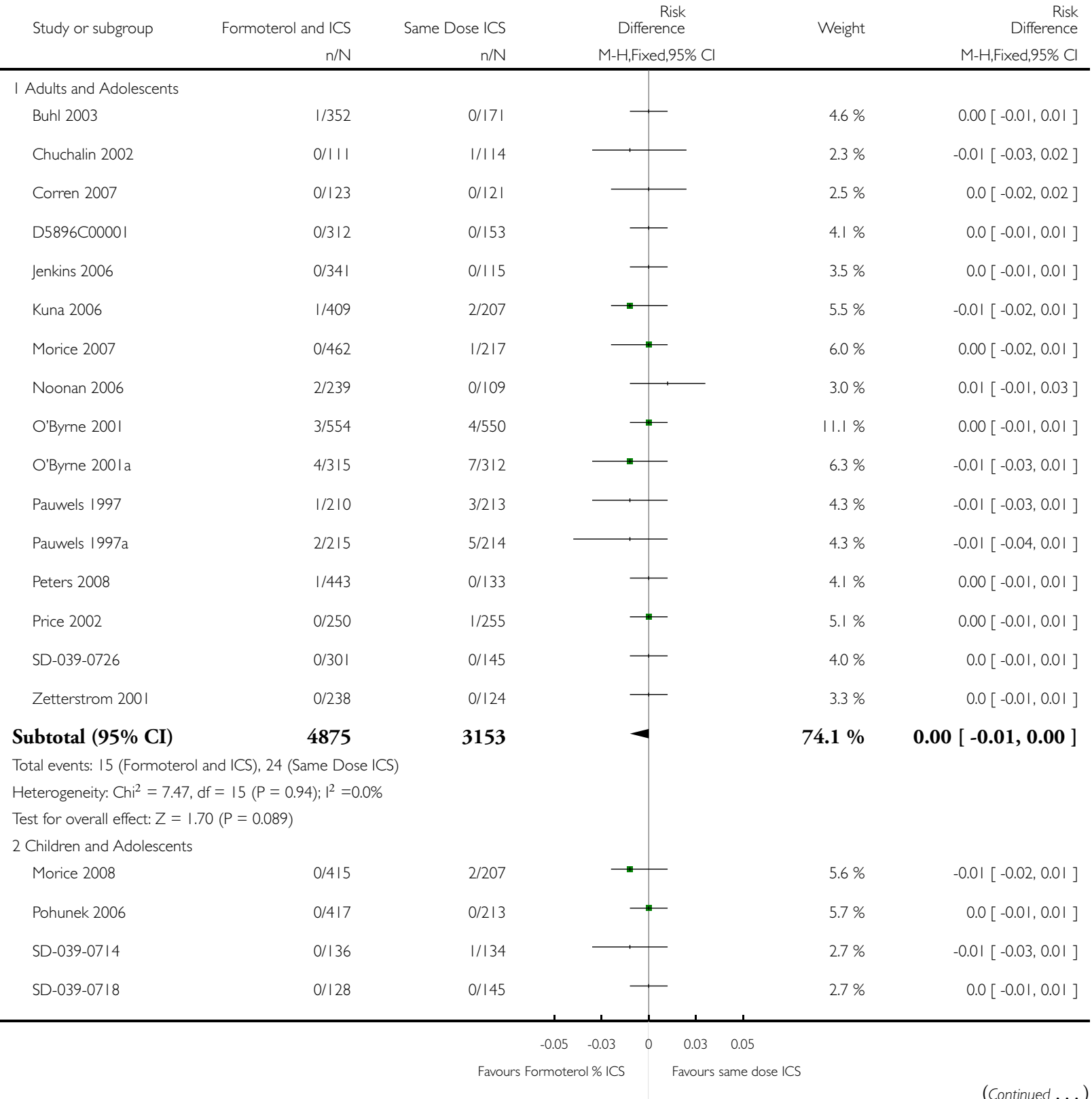




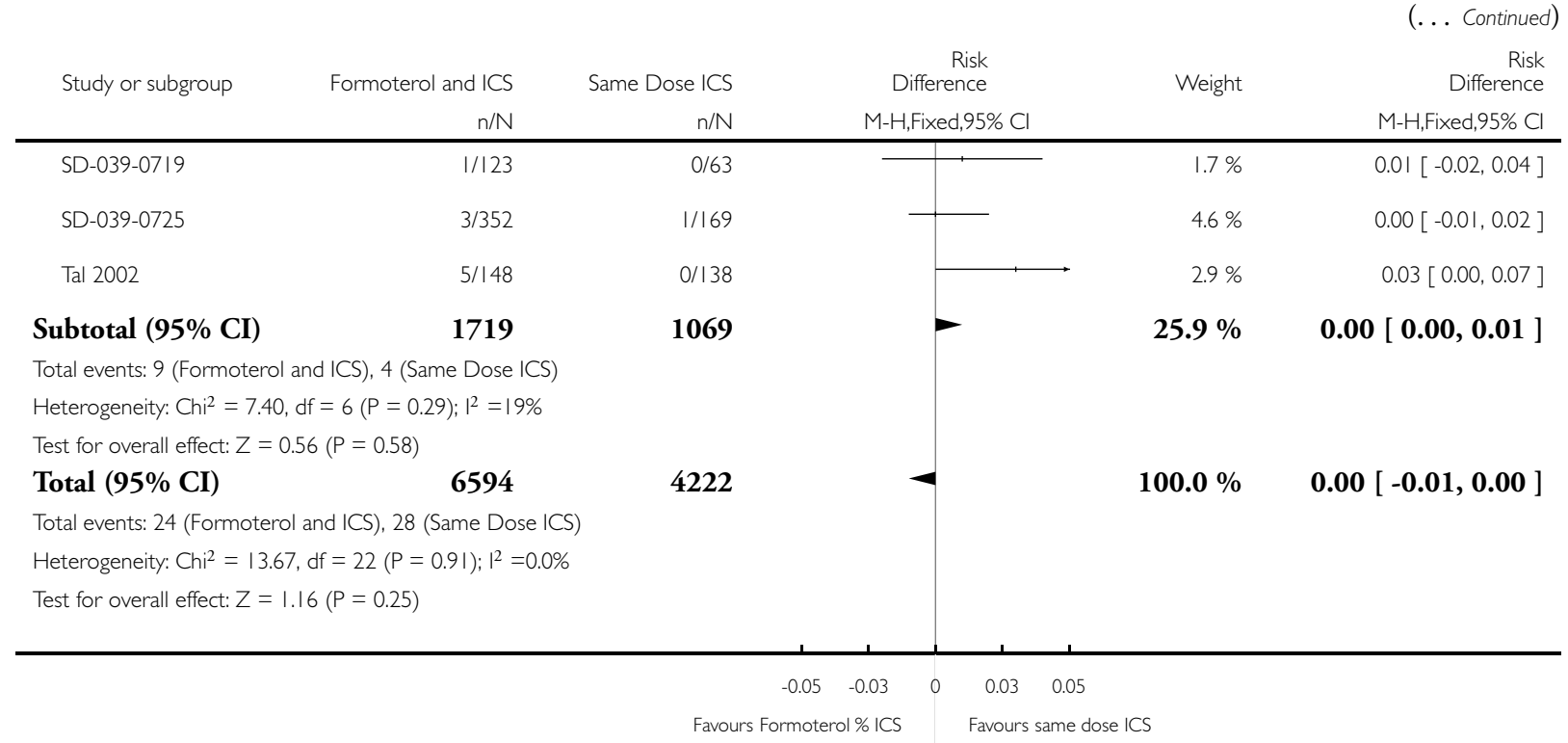

Analysis I.8. Comparison I Formoterol and ICS versus same dose ICS, Outcome 8 All-cause Mortality (Mantel-Haenszel fixed).

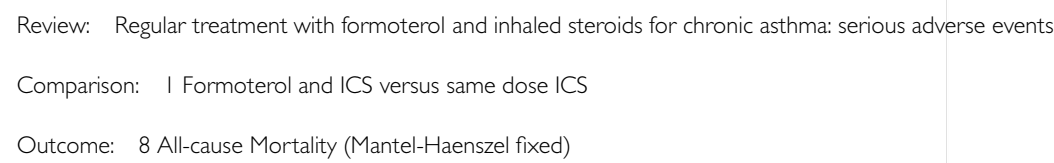

1/352

Chuchalin 2002

0/111 0/114

Corren 2007

$0 / 123 \quad 0 / 121$

D5896C0000।

$0 / 312$

$0 / 153$

Jenkins 2006

$0 / 341$

$0 / 115$

Kuna 2006

0/409

0/207

Morice 2007

$0 / 462$

$0 / 217$

$1.46[0.06,36.12]$

$0.0[0.0,0.0]$

$0.0[0.0,0.0]$

$0.0[0.0,0.0]$

$0.0[0.0,0.0]$

$0.0[0.0,0.0]$

$0.0[0.0,0.0]$

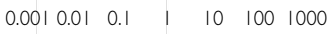

Favours Formoterol \% ICS Favours same dose ICS

(Continued....) 


\begin{tabular}{|c|c|c|c|c|}
\hline \multirow[t]{2}{*}{ Study or subgroup } & \multirow{2}{*}{$\begin{array}{r}\text { Formoterol and ICS } \\
\mathrm{n} / \mathrm{N}\end{array}$} & \multirow[t]{2}{*}{$\begin{array}{r}\text { Same Dose ICS } \\
n / N\end{array}$} & $\begin{array}{l}\text { Odds Ratio } \\
\text { M-HFixed } 95 \% \text { (a) }\end{array}$ & $\begin{array}{c}\text { (... Continued) } \\
\text { Odds Ratio }\end{array}$ \\
\hline & & & M-H,Fixed,95\% Cl & M-H,Fixed,95\% Cl \\
\hline Noonan 2006 & 0/239 & 0/109 & & $0.0[0.0,0.0]$ \\
\hline O'Byrne 2001 & 1/554 & $0 / 550$ & $=$ & $2.98[0.12,73.40]$ \\
\hline O'Byrne 200 la & 0/315 & $0 / 312$ & & $0.0[0.0,0.0]$ \\
\hline Pauwels 1997 & $0 / 210$ & $0 / 213$ & & $0.0[0.0,0.0]$ \\
\hline Pauwels 1997a & $1 / 215$ & $0 / 214$ & 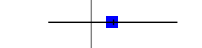 & $3.00[0.12,74.06]$ \\
\hline Peters 2008 & $0 / 443$ & 0/133 & & $0.0[0.0,0.0]$ \\
\hline Price 2002 & 0/250 & 0/255 & & $0.0[0.0,0.0]$ \\
\hline SD-039-0726 & 0/301 & $0 / 145$ & & $0.0[0.0,0.0]$ \\
\hline Zetterstrom 2001 & 1/238 & $0 / 124$ & 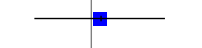 & $1.57[0.06,38.89]$ \\
\hline Subtotal $(95 \% \mathrm{CI})$ & 4875 & 3153 & - & $2.15[0.43,10.67]$ \\
\hline \multicolumn{5}{|c|}{ Total events: 4 (Formoterol and ICS), 0 (Same Dose ICS) } \\
\hline \multicolumn{5}{|c|}{ Heterogeneity: $\mathrm{Chi}^{2}=0.17, \mathrm{df}=3(\mathrm{P}=0.98) ; \mathrm{I}^{2}=0.0 \%$} \\
\hline \multicolumn{5}{|c|}{ Test for overall effect: $Z=0.94(P=0.35)$} \\
\hline \multicolumn{5}{|l|}{2 Children and Adolescents } \\
\hline Morice 2008 & 0/415 & 0/207 & & $0.0[0.0,0.0]$ \\
\hline Pohunek 2006 & 0/417 & $0 / 213$ & & $0.0[0.0,0.0]$ \\
\hline SD-039-07।4 & $0 / 136$ & 0/134 & & $0.0[0.0,0.0]$ \\
\hline SD-039-07/8 & $0 / 128$ & $0 / 145$ & & $0.0[0.0,0.0]$ \\
\hline SD-039-0719 & 0/123 & $0 / 63$ & & $0.0[0.0,0.0]$ \\
\hline SD-039-0725 & 0/352 & $0 / 169$ & & $0.0[0.0,0.0]$ \\
\hline Tal 2002 & $0 / 148$ & $0 / 138$ & & $0.0[0.0,0.0]$ \\
\hline Subtotal (95\% CI) & 1719 & 1069 & & $0.0[0.0,0.0]$ \\
\hline \multicolumn{5}{|c|}{ Total events: 0 (Formoterol and ICS), 0 (Same Dose ICS) } \\
\hline \multicolumn{5}{|c|}{ Heterogeneity: $\mathrm{Chi}^{2}=0.0, \mathrm{df}=0(\mathrm{P}<0.0000 \mathrm{I}) ; \mathrm{I}^{2}=0.0 \%$} \\
\hline \multicolumn{5}{|c|}{ Test for overall effect: $Z=0.0(P<0.0000 \mathrm{I})$} \\
\hline Total $(95 \% \mathrm{CI})$ & 6594 & 4222 & & $2.15[0.43,10.67]$ \\
\hline \multicolumn{5}{|c|}{ Total events: 4 (Formoterol and ICS), 0 (Same Dose ICS) } \\
\hline \multicolumn{5}{|c|}{ Heterogeneity: $C h i^{2}=0.17, d f=3(P=0.98) ;\left.\right|^{2}=0.0 \%$} \\
\hline Test for overall effect: $Z=$ & $=0.35)$ & & & \\
\hline
\end{tabular}


Analysis I.9. Comparison I Formoterol and ICS versus same dose ICS, Outcome 9 All-cause non-fatal Serious Adverse Events (Mantel-Haenszel fixed).

Review: Regular treatment with formoterol and inhaled steroids for chronic asthma: serious adverse events

Comparison: I Formoterol and ICS versus same dose ICS

Outcome: 9 All-cause non-fatal Serious Adverse Events (Mantel-Haenszel fixed)

\begin{tabular}{|c|c|c|c|c|}
\hline \multirow[t]{2}{*}{ Study or subgroup } & \multirow{2}{*}{$\begin{array}{r}\text { Formoterol and ICS } \\
n / N\end{array}$} & \multirow{2}{*}{$\begin{array}{r}\text { Same Dose ICS } \\
n / N\end{array}$} & Odds Ratio & \multirow{2}{*}{$\begin{array}{r}\text { Odds Ratio } \\
\text { M-H,Fixed,95\% Cl }\end{array}$} \\
\hline & & & M-H,Fixed,95\% Cl & \\
\hline \multicolumn{5}{|l|}{ I Adults and Adolescents } \\
\hline Buhl 2003 & $2 / 352$ & $2 / 171$ & $1 \cdot$ & $0.48[0.07,3.46]$ \\
\hline Chuchalin 2002 & $0 / 111$ & $2 / 114$ & E & $0.20[0.01,4.25]$ \\
\hline Corren 2007 & $2 / 123$ & $0 / 121$ & - & $5.00[0.24,105.24]$ \\
\hline D5896C0000I & $3 / 312$ & $0 / 153$ & 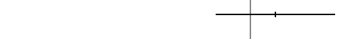 & $3.47[0.18,67.64]$ \\
\hline Jenkins 2006 & $7 / 341$ & $3 / 115$ & ' & $0.78[0.20,3.08]$ \\
\hline Kuna 2006 & $3 / 409$ & $4 / 207$ & $\longrightarrow$ & $0.38[0.08,1.69]$ \\
\hline Morice 2007 & $2 / 462$ & $2 / 217$ & $\longrightarrow$ & $0.47[0.07,3.34]$ \\
\hline Noonan 2006 & $7 / 239$ & $0 / 109$ & _ & $7.06[0.40, \mid 24.81]$ \\
\hline O'Byrne 200I & $20 / 554$ & $23 / 550$ & $=$ & $0.86[0.47,1.58]$ \\
\hline O'Byrne $2001 \mathrm{a}$ & $15 / 315$ & $19 / 312$ & + & $0.77[0.38,1.55]$ \\
\hline Pauwels 1997 & $10 / 210$ & $9 / 213$ & $\rightarrow$ & $1.13[0.45,2.85]$ \\
\hline Pauwels 1997a & $15 / 215$ & $12 / 214$ & $\rightarrow$ & $1.26[0.58,2.76]$ \\
\hline Peters 2008 & $21 / 443$ & $5 / 133$ & - & $1.27[0.47,3.45]$ \\
\hline Price 2002 & $2 / 250$ & $3 / 255$ & 1 & $0.68[0.11,4.09]$ \\
\hline SD-039-0726 & $4 / 301$ & $1 / 145$ & 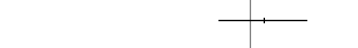 & $1.94[0.21,17.51]$ \\
\hline Zetterstrom 2001 & $3 / 238$ & $1 / 124$ & 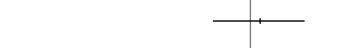 & $1.57[0.16,15.25]$ \\
\hline Subtotal (95\% CI) & 4875 & 3153 & - & $0.98[0.74,1.31]$ \\
\hline \multicolumn{5}{|c|}{ Total events: II 6 (Formoterol and ICS), 86 (Same Dose ICS) } \\
\hline \multicolumn{5}{|c|}{ Heterogeneity: $\mathrm{Chi}^{2}=9.46, \mathrm{df}=15(\mathrm{P}=0.85) ; \mathrm{I}^{2}=0.0 \%$} \\
\hline \multicolumn{5}{|c|}{ Test for overall effect: $Z=0.12(P=0.91)$} \\
\hline \multicolumn{5}{|c|}{2 Children and Adolescents } \\
\hline Morice 2008 & $2 / 415$ & $3 / 207$ & + & $0.33[0.05,1.99]$ \\
\hline Pohunek 2006 & $8 / 417$ & $3 / 213$ & $\longrightarrow$ & $1.37[0.36,5.21]$ \\
\hline SD-039-07/4 & $1 / 136$ & $1 / 134$ & - & $0.99[0.06,15.91]$ \\
\hline SD-039-07।8 & $0 / 128$ & $0 / 145$ & & $0.0[0.0,0.0]$ \\
\hline SD-039-07।9 & $2 / 123$ & $1 / 63$ & \begin{tabular}{l|l}
+ \\
\end{tabular} & $1.02[0.09,11.52]$ \\
\hline & & & $0.0010 .01 \quad 0.1 \quad 1 \quad 10 \quad 100$ & \\
\hline & & & Favours Formoterol \% ICS & \\
\hline
\end{tabular}




\begin{tabular}{|c|c|c|c|c|}
\hline \multirow[t]{2}{*}{ Study or subgroup } & Formoterol and ICS & Same Dose ICS & Odds Ratio & $\begin{array}{l}\text { (... Continued) } \\
\text { Odds Ratio }\end{array}$ \\
\hline & $\mathrm{n} / \mathrm{N}$ & $n / N$ & M-H,Fixed,95\% Cl & M-H,Fixed,95\% Cl \\
\hline SD-039-0725 & $5 / 352$ & $1 / 169$ & —— & $2.42[0.28,20.88]$ \\
\hline Tal 2002 & $7 / 148$ & $0 / 138$ & & I4.68 [0.83, 259.54] \\
\hline Subtotal $(95 \% \mathrm{CI})$ & 1719 & 1069 & - & $1.62[0.77,3.38]$ \\
\hline \multicolumn{5}{|c|}{ Total events: 25 (Formoterol and ICS), 9 (Same Dose ICS) } \\
\hline \multicolumn{5}{|c|}{ Heterogeneity: $\mathrm{Ch}^{2}=5.73, \mathrm{df}=5(P=0.33) ;\left.\right|^{2}=13 \%$} \\
\hline \multicolumn{5}{|c|}{ Test for overall effect: $Z=1.27(P=0.20)$} \\
\hline Total $(95 \% \mathrm{CI})$ & 6594 & 4222 & $\bullet$ & $1.06[0.81,1.38]$ \\
\hline \multicolumn{5}{|c|}{ Total events: I4I (Formoterol and ICS), 95 (Same Dose ICS) } \\
\hline \multicolumn{5}{|c|}{ Heterogeneity: $\mathrm{Chi}^{2}=15.48, \mathrm{df}=21 \quad(P=0.80) ;\left.\right|^{2}=0.0 \%$} \\
\hline Test for overall effect: $Z=$ & $=0.69)$ & & & \\
\hline
\end{tabular}

Analysis I.I0. Comparison I Formoterol and ICS versus same dose ICS, Outcome IO All-cause non-fatal Serious Adverse Events (sensitivity analysis without unblinded study).

Review: Regular treatment with formoterol and inhaled steroids for chronic asthma: serious adverse events

Comparison: I Formoterol and ICS versus same dose ICS

Outcome: 10 All-cause non-fatal Serious Adverse Events (sensitivity analysis without unblinded study)

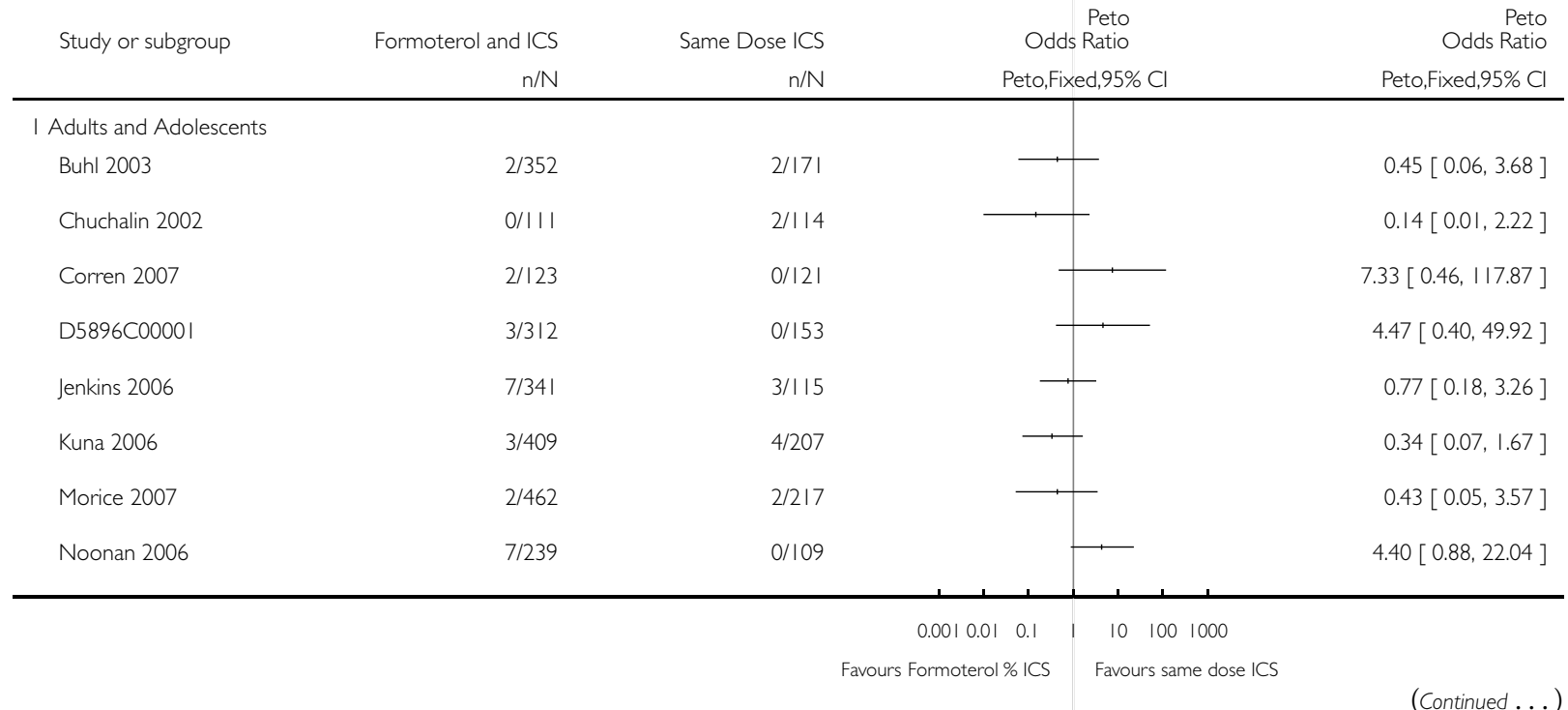




\begin{tabular}{|c|c|c|c|c|}
\hline \multirow[t]{2}{*}{ Study or subgroup } & Formoterol and ICS & Same Dose ICS & $\begin{array}{r}\text { Peto } \\
\text { Odds Ratio }\end{array}$ & $\begin{array}{r}\text { (... Continued) } \\
\text { Peto } \\
\text { Odds Ratio }\end{array}$ \\
\hline & $\mathrm{n} / \mathrm{N}$ & $\mathrm{n} / \mathrm{N}$ & Peto,Fixed,95\% Cl & Peto,Fixed,95\% Cl \\
\hline O'Byrne 200I & $20 / 554$ & $23 / 550$ & 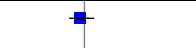 & $0.86[0.47,1.58]$ \\
\hline O'Byrne 200 la & $15 / 315$ & $19 / 312$ & 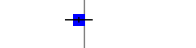 & $0.77[0.39,1.54]$ \\
\hline Pauwels 1997 & $10 / 210$ & $9 / 213$ & $\rightarrow$ & $1.13[0.45,2.84]$ \\
\hline Pauwels 1997a & $15 / 215$ & $12 / 214$ & - & $1.26[0.58,2.75]$ \\
\hline Peters 2008 & $21 / 443$ & $5 / 133$ & $\rightarrow$ & $1.26[0.49,3.19]$ \\
\hline Price 2002 & $2 / 250$ & 3/255 & $\longrightarrow$ & $0.68[0.12,3.96]$ \\
\hline SD-039-0726 & $4 / 301$ & $1 / 145$ & - & $1.78[0.27,11.65]$ \\
\hline Zetterstrom 2001 & $3 / 238$ & $1 / 124$ & ـ & $1.51[0.19,12.04]$ \\
\hline Subtotal $(95 \%$ CI $)$ & 4875 & 3153 & - & $0.99[0.74,1.33]$ \\
\hline \multicolumn{5}{|c|}{ Total events: II 6 (Formoterol and ICS), 86 (Same Dose ICS) } \\
\hline \multicolumn{5}{|c|}{ Heterogeneity: $\mathrm{Ch}^{2}=13.79, \mathrm{df}=15(P=0.54) ; 1^{2}=0.0 \%$} \\
\hline \multicolumn{5}{|c|}{ Test for overall effect: $Z=0.07(P=0.95)$} \\
\hline \multicolumn{5}{|l|}{2 Children and Adolescents } \\
\hline Morice 2008 & $2 / 415$ & $3 / 207$ & - & $0.30[0.05,1.93]$ \\
\hline Pohunek 2006 & $8 / 417$ & $3 / 213$ & - & $1.35[0.38,4.74]$ \\
\hline SD-039-07/4 & $1 / 136$ & $1 / 134$ & - & $0.99[0.06,15.83]$ \\
\hline SD-039-07/8 & $0 / 128$ & $0 / 145$ & & $0.0[0.0,0.0]$ \\
\hline SD-039-0725 & $5 / 352$ & $1 / 169$ & + & $2.07[0.37,11.52]$ \\
\hline Tal 2002 & $7 / 148$ & $0 / 138$ & 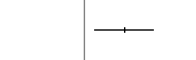 & $7.20[1.61,32.21]$ \\
\hline Subtotal $(95 \% \mathrm{CI})$ & 1596 & 1006 & - & $1.69[0.81,3.54]$ \\
\hline \multicolumn{5}{|c|}{ Total events: 23 (Formoterol and ICS), 8 (Same Dose ICS) } \\
\hline \multicolumn{5}{|c|}{ Heterogeneity: Chi $^{2}=7.24, d f=4(P=0.12) ; 1^{2}=45 \%$} \\
\hline \multicolumn{5}{|c|}{ Test for overall effect: $Z=1.39(P=0.16)$} \\
\hline Total $(95 \% \mathrm{CI})$ & 6471 & 4159 & - & $1.06[0.81,1.40]$ \\
\hline \multicolumn{5}{|c|}{ Total events: 139 (Formoterol and ICS), 94 (Same Dose ICS) } \\
\hline \multicolumn{5}{|c|}{ Heterogeneity: $\mathrm{Ch}^{2}=22.78, \mathrm{df}=20(\mathrm{P}=0.30) ; 1^{2}=12 \%$} \\
\hline \multicolumn{5}{|c|}{ Test for overall effect: $Z=0.45(P=0.65)$} \\
\hline Test for subgroup differen & $=1.75, \mathrm{df}=1(P=0.19$ & & & \\
\hline
\end{tabular}


ADDITIONAL TABLES

Table 1. Dose and delivery of budesonide and formoterol

\begin{tabular}{|c|c|c|c|c|c|c|c|c|}
\hline Study ID & $\begin{array}{l}\text { Daily Dose } \\
\text { of Budes- } \\
\text { onide (mcg } \\
\text { metered } \\
\text { dose) }\end{array}$ & $\begin{array}{l}\begin{array}{l}\text { Daily Dose } \\
\text { of }\end{array} \\
\text { Formoterol } \\
\text { (mcg me- } \\
\text { tered dose) }\end{array}$ & Once & Twice & Combined & Separate & DPI & PMDI \\
\hline Buhl 2003 & 400 & 12 & 1 & 1 & 1 & & 1 & \\
\hline $\begin{array}{l}\text { Chuchalin } \\
2002\end{array}$ & 400 & 24 & & 1 & & 1 & 1 & \\
\hline $\begin{array}{l}\text { Corren } \\
2007\end{array}$ & 400 & 24 & & 1 & 1 & & 1 & \\
\hline D5896C0000 & 400 & $12 / 24$ & 1 & 1 & 1 & & & 1 \\
\hline $\begin{array}{l}\text { Jenkins } \\
2006\end{array}$ & 1600 & 48 & & 1 & 1 & 1 & 1 & \\
\hline Kuna 2006 & 200 & 12 & 1 & 1 & 1 & & 1 & \\
\hline $\begin{array}{l}\text { Morice } \\
2007\end{array}$ & 800 & 24 & & 1 & 1 & & 1 & 1 \\
\hline $\begin{array}{l}\text { Morice } \\
2008\end{array}$ & $\begin{array}{l}200 \\
\text { (children) }\end{array}$ & 24 & & 1 & 1 & & 1 & 1 \\
\hline $\begin{array}{l}\text { Noonan } \\
2006\end{array}$ & 400 & 24 & & 1 & 1 & 1 & 1 & 1 \\
\hline $\begin{array}{l}\text { O'Byrne } \\
2001\end{array}$ & 400 & 12 & & 1 & & 1 & 1 & \\
\hline $\begin{array}{l}\text { O’Byrne } \\
\text { 2001a }\end{array}$ & 800 & 12 & & 1 & & 1 & 1 & \\
\hline $\begin{array}{l}\text { Pauwels } \\
1997\end{array}$ & 200 & 24 & & 1 & & 1 & 1 & \\
\hline $\begin{array}{l}\text { Pauwels } \\
1997 a\end{array}$ & 800 & 24 & & 1 & & 1 & 1 & \\
\hline Peters 2008 & 1600 & 48 & & 1 & 1 & & & 1 \\
\hline $\begin{array}{l}\text { Pohunek } \\
2006\end{array}$ & $\begin{array}{l}400 \\
\text { (children) }\end{array}$ & 24 & & 1 & 1 & 1 & 1 & \\
\hline Price 2002 & 800 & 24 & & 1 & & 1 & 1 & \\
\hline
\end{tabular}


Table 1. Dose and delivery of budesonide and formoterol (Continued)

\begin{tabular}{|c|c|c|c|c|c|c|c|c|}
\hline $\begin{array}{l}\text { SD-039- } \\
0714\end{array}$ & $\begin{array}{l}400 \text { (adoles- } \\
\text { cents) }\end{array}$ & 12 & & 1 & 1 & & 1 & \\
\hline $\begin{array}{l}\text { SD-039- } \\
0718\end{array}$ & $\begin{array}{l}200 \\
\text { (children) }\end{array}$ & 24 & & 1 & 1 & & & 1 \\
\hline $\begin{array}{l}\text { SD-039- } \\
0719\end{array}$ & $\begin{array}{l}400 \\
\text { (children) }\end{array}$ & 24 & & 1 & 1 & & & 1 \\
\hline $\begin{array}{l}\text { SD-039- } \\
0725\end{array}$ & $\begin{array}{l}200 \\
\text { (children) }\end{array}$ & $12 / 24$ & 1 & 1 & 1 & & & 1 \\
\hline $\begin{array}{l}\text { SD-039- } \\
0726\end{array}$ & 200 & $12 / 24$ & 1 & 1 & 1 & & & 1 \\
\hline Tal 2002 & $\begin{array}{l}400 \\
\text { (children) }\end{array}$ & 24 & & 1 & 1 & & 1 & \\
\hline $\begin{array}{l}\text { Zetterstrom } \\
2001\end{array}$ & 800 & 24 & & 1 & 1 & 1 & 1 & \\
\hline
\end{tabular}

\section{A P PEN D I CES}

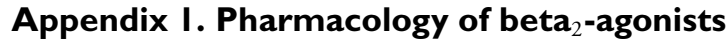

ß-agonists are thought to cause bronchodilation primarily through binding beta 2 -adrenoceptors on airways smooth muscle (ASM), with subsequent activation of both membrane-bound potassium channels and a signalling cascade involving enzyme activation and changes in intracellular calcium levels following a rise in cyclic adenosine monophosphate (cAMP) (Barnes 1993). However, beta2adrenoceptors are also expressed on a wide range of cell types where beta2-agonists may have a clinically significant effect including airway epithelium (Morrison 1993), mast cells, post capillary venules, sensory and cholinergic nerves and dendritic cells (Anderson

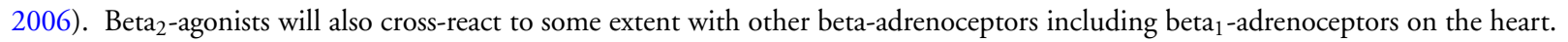
The in vivo effect of any beta 2 -agonist will depend on a number of factors relating to both the drug and the patient. The degree to which a drug binds to one receptor over another is known as selectivity, which can be defined as absolute binding ratios to different receptors in vitro, whilst functional selectivity is measured from downstream effects of drugs in different tissue types in vitro or in vivo.

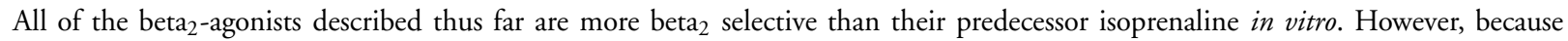
attempts to differentiate selectivity between the newer agents are confounded by so many factors, it is difficult to draw conclusions about in vitro selectivity studies and probably best to concentrate on specific adverse side-effects in human subjects at doses which cause the same degree of bronchodilatation. The potency of a drug refers to the concentration that achieves half the maximal receptor activation of which that drug is capable but it is not very important clinically as for each drug, manufacturers will alter the dose to try to achieve a therapeutic ratio of desired to undesired effects. In contrast efficacy refers to the ability of a drug to activate its receptor independent of drug concentration. Drugs that fully activate a receptor are known as full agonists and those that partially activate a receptor are known as partial agonists. Efficacy also is very much dependent on the system in which it is being tested and is affected by factors including the number of receptors available and the presence of other agonists and antagonists. Thus whilst salmeterol acts as a partial agonist in vitro it causes a similar degree of bronchodilation to the strong agonist formoterol in stable asthmatic patients (vanNoord 1996), presumably because there are an abundance of well-coupled beta 2 -adrenoceptors available with few downstream 
antagonising signals. In contrast, with repetitive dosing formoterol is significantly better than salmeterol at preventing methacholineinduced bronchoconstriction (Palmqvist 1999). These differences have led to attempts to define the "intrinsic efficacy" of a drug independent of tissue conditions (Hanania 2002), as shown in Table 1. The clinical significance of intrinsic efficacy remains unclear.

\section{Po}

\section{Appendix 2. Possible mechanisms of increased asthma mortality with beta-agonists}

\section{Direct toxicity}

This hypothesis states that direct adverse effects of beta2-agonists are responsible for an associated increase in mortality and most research in the area has concentrated on effects detrimental to the heart. Whilst it is often assumed that cardiac side-effects of beta2agonists are due to cross-reactivity with beta ${ }_{1}$-adrenoceptors (i.e. poor selectivity), it is worth noting that human myocardium also contains an abundance of beta 2 -adrenoceptors capable of triggering positive chronotropic and inotropic responses (Lipworth 1992). Indeed, there is good evidence that cardiovascular side-effects of isoprenaline (Arnold 1985) and beta2-agonists including salbutamol (Hall 1989) are mediated predominantly via cardiac beta2-adrenoceptors thus making the concept of in vitro selectivity less relevant. Generalised beta 2 -adrenoceptor activation can also cause hypokalaemia (Brown 1983) and it has been proposed that, through these and other actions, beta 2 -agonists may predispose to life-threatening dysrhythmias or cause other adverse cardiac effects.

During the 1960s epidemic most deaths occurred in patients with severe asthma and it was originally assumed that asthma and its sequelae, including hypoxia, were the primary cause of death. However, mucus plugging and hypoxia does not preclude a cardiac event as the final cause of death, and one might expect those with severe asthma to take more doses of a prescribed inhaler. As noted by Speizer and Doll most deaths in the 1960s were in the 10-19 age group and "at these ages children have begun to act independently and may be particularly prone to misuse a self-administered form of treatment" (Speizer 1968). If toxicity were related to increasing doses of beta $_{2}$-agonists one might expect most deaths to occur in hospital where high doses are typically used and this was not the case. One possible explanation for this anomaly was provided by animal experiments in which large doses of isoprenaline caused little ill effect in anaesthetised dogs with normal arterial oxygenation whereas much smaller doses caused fatal cardiac depression and asystole (although no obvious dysrhythmia) when hypoxic (Collins 1969; McDevitt 1974). It has been hypothesised therefore that such events would be less likely in hospital where supplemental oxygen is routinely given. The clinical relevance of these studies remains unclear although there is some evidence of a synergistic effect between hypoxia and salbutamol use in asthmatic patients in reducing total peripheral vascular resistance (Burggraaf 2001) - another beta 2 mediated effect which could be detrimental to the heart during an acute asthma attack through a reduction in diastolic blood pressure. Other potential mechanisms of isoprenaline toxicity include a potential increase in mucous plugging and worsening of ventilation perfusion mismatch despite bronchodilation (Pearce 1990).

Further concerns about a possible toxic effect of beta 2 -agonists were raised during the New Zealand epidemic in the 1970s. In 1981 Wilson et al who first reported the epidemic reviewed 22 fatal cases of asthma and noted "In 16 patients death was seen to be sudden and unexpected. Although all were experiencing respiratory distress, most were not cyanosed and the precipitate nature of their death suggested a cardiac event, such as an arrest, inappropriate to the severity of their respiratory problem" (Wilson 1981). In humans, fenoterol causes significantly greater chronotropic, inotropic and electrocardiographic side-effects than salbutamol in asthmatic patients (Wong 1990). Interestingly, across the same parameters fenoterol also causes more side-effects than isoprenaline (Burgess 1991).

In patients with mild asthma and without a bronchoconstrictor challenge, salmeterol and salbutamol cause a similar degree of near maximal bronchodilation at low doses (Bennett 1994). However, whilst as a one off dose salbutamol is typically used at 2-4 times the concentration of salmeterol, the dose equivalences for salmeterol versus salbutamol in increasing heart rate and decreasing potassium concentration and diastolic blood pressure were 17.7, 7.8 and 7.6 respectively (i.e. salmeterol had a greater effect across all parameters). Given the lower intrinsic efficacy of salmeterol (Table 2), these results highlight the importance of in vivo factors; one possible explanation for the difference is the increased lipophilicity of salmeterol compared to salbutamol contributing to higher systemic absorption (Bennett 1994).

When comparing increasing actuations of standard doses of formoterol and salmeterol inhalers in stable asthmatic patients, relatively similar cardiovascular effects are seen at lower doses (Guhan 2000). However, at the highest doses (above those recommended by the manufacturers) there were trends towards an increase in systolic blood pressure with formoterol; in comparison there was a trend towards a decrease in diastolic blood pressure and an increase in QTc interval with salmeterol although no statistical analysis of the difference was performed. In contrast in asthmatic patients with methacholine-induced bronchoconstriction there was no significant

Regular treatment with formoterol and inhaled steroids for chronic asthma: serious adverse events (Review) 
difference between salmeterol and formoterol in causing increased heart rate and QTc interval although formoterol caused significantly greater bronchodilation and hypokalaemia (Palmqvist 1999). Whilst there is good evidence of cardiovascular and metabolic side-effects with increasing doses of beta 2 -agonists, it is a little difficult to envisage serious adverse effects of this nature when using LABAs at manufacturer-recommended preventative doses. However, it is possible that some patients choose to use repeated doses of LABAs during exacerbations.

\section{Tolerance}

In this setting, the term tolerance refers to an impaired response to beta 2 -agonists in patients who have been using regular beta 2 agonist treatment previously (Haney 2006). Tolerance is likely to result from a combination of reduced receptor numbers secondary to receptor internalisation and reduced production and also uncoupling of receptors to downstream signalling pathways following repeated activation (Barnes 1995). This phenomenon is likely to explain the beneficial reduction in systemic side effects seen with

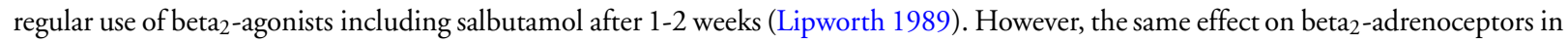
the lung might be expected to produce a diminished response to the bronchodilating activity of beta 2 -agonists following regular use. In patients with stable asthma, whilst there is some evidence of tolerance to both salbutamol (Nelson 1977) and terbutaline (Weber 1982) other studies have been less conclusive (Harvey 1982; Lipworth 1989). However, evidence of tolerance to short and long-acting beta2agonists in both protecting against and reducing bronchoconstriction is much stronger in the setting of an acute bronchoconstrictor challenge with chemical, allergen and 'natural' stimuli ( Haney 2006; Lipworth 1997).

Studies comparing salmeterol and formoterol have shown that both cause tolerance compared to placebo but there was no significant difference between the drugs (van der Woude 2001). There also appears to be little difference in the tolerance induced by regular formoterol and regular salbutamol treatment (Hancox 1999; Jones 2001). To the authors' knowledge no studies have looked specifically at the degree of tolerance caused by isoprenaline and fenoterol in the setting of acute bronchoconstriction. Tolerance to bronchodilation has been shown to clearly occur with addition of inhaled corticosteroids to salmeterol and formoterol (Lee 2003) and terbutaline (Yates 1996). There is conflicting evidence as to whether high dose steroids can reverse tolerance in the acute setting (Lipworth 2000; Jones 2001).

At first glance the toxicity and tolerance hypotheses might appear incompatible as systemic and cardiovascular tolerance ought to protect against toxicity in the acute setting and there is good evidence that such tolerance occurs in stable asthmatic patients (Lipworth 1989). However, whilst this study showed that changes in heart rate and potassium levels were blunted by previous beta 2 -agonist use, they were not abolished; furthermore, at the doses studied these side-effects appear to follow an exponential pattern (Lipworth 1989). In contrast, in the presence of bronchoconstrictor stimuli the bronchodilator response to beta 2 -agonists follows a flatter curve (Wong 1990; Hancox 1999) and as previously discussed this curve is shifted downwards by previous beta 2 -agonist exposure (Hancox 1999). Thus, it is theoretically possible that in the setting of an acute asthmatic attack and strong bronchoconstricting stimuli, bronchodilator tolerance could lead to repetitive beta2-agonist use and ultimately more systemic side-effects than would otherwise have occurred. Of course, other sequelae of inadequate bronchodilation including airway obstruction will be detrimental in this setting.

Whilst the tolerance hypothesis is often cited as contributing towards the asthma mortality epidemics it is difficult to argue that reduced efficacy of a drug can cause increased mortality relative to a time when that drug was not used at all. However, tolerance to the bronchodilating effect of endogenous circulating adrenaline is theoretically possible and there is also evidence of rebound bronchoconstriction when stopping fenoterol (Sears 1990), which may be detrimental. Furthermore, it appears that regular salbutamol treatment can actually increase airway responsiveness to allergen (Cockcroft 1993) a potentially important effect that could form a variant of the toxicity hypothesis. Differences between beta 2 -agonists in this regard are unclear, but the combination of rebound hyperresponsiveness and tolerance of the bronchodilator effect with regular beta 2 -agonist exposure has been recently advocated as a possible mechanism to explain the association between beta 2 -agonists and asthma mortality (Hancox 2006).

\section{Other explanations}

\section{Confounding by severity}

Historically, this hypothesis has been used extensively to try to explain the association between mortality and the use of fenoterol during the 1970s New Zealand epidemic (see Pearce 2007) and is still quoted today. The hypothesis essentially relies on the supposition that

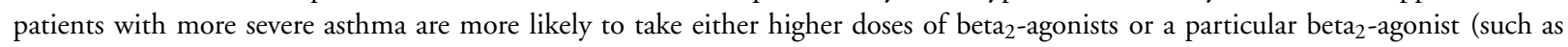
fenoterol) thereby explaining the association. This hypothesis was carefully ruled out in the three case-control studies by comparing the association between fenoterol and mortality in patients with varying severity of disease (Crane 1989; Pearce 1990; Grainger 1991).

Regular treatment with formoterol and inhaled steroids for chronic asthma: serious adverse events (Review) 
Furthermore, the hypothesis cannot explain the overall increase in mortality in the 1960s and 1970s nor can it explain any significant increase in mortality (whether taking inhaled steroids or not) from randomised controlled trial data.

\section{The delay hypothesis}

This hypothesis accepts that beta 2 -agonists or a particular beta ${ }_{2}$-agonist cause an increased risk of mortality but indirectly by causing patients to delay before getting medical help and further treatments including high dose steroids and oxygen. There is evidence that both salmeterol and formoterol can reduce awareness of worsening underlying inflammation (Bijl-Hofland 2001; McIvor 1998). It is difficult to rule out the delay hypothesis in either explaining or contributing towards both the asthma mortality epidemics and an association with regular use of LABAs. There is evidence that beta 2 -agonists with higher intrinsic efficacy are more effective at relieving bronchoconstriction in the acute setting (Hanania 2007) and could paradoxically cause patients to delay seeking medical help for longer. For the delay hypothesis to explain the increase in mortality during the 1960s and 1970s one has to imply that hospital treatment of asthma when mortality rates were low during the earlier years of the $20^{\text {th }}$ century was effective. It is difficult to say exactly how effective such treatment is likely to have been.

\section{Reduced corticosteroid treatment}

A slight but significant variation of the delay hypothesis suggests that patients who have separate beta 2 -agonists and corticosteroid inhalers may choose to take less corticosteroid because of better symptom control from the inhaled beta 2 -agonists and it is reduced corticosteroid treatment that contributes to a rise in mortality. It is rather difficult to see how this hypothesis explains the epidemics of asthma deaths in the 1960s and 1970s relative to the 1920s and 30s (Figure 1), given that corticosteroids were not used for the treatment of asthma in the earlier decades. If this hypothesis were to explain increased mortality from more recent randomised controlled trial data one would not expect to see an increase in mortality in those taking LABAs alone.

\section{Appendix 3. Definition of Serious Adverse Events}

The Expert Working Group (Efficacy) of the International Conference on Harmonisation of Technical Requirements for Registration of Pharmaceuticals for Human Use (ICH) define serious adverse events as follows (ICHE2a 1995):

"A serious adverse event (experience) or reaction is any untoward medical occurrence that at any dose:

- Results in death,

- Is life-threatening,

- Requires inpatient hospitalization or prolongation of existing hospitalization,

- Results in persistent or significant disability/incapacity, or

- Is a congenital anomaly/birth defect.

NOTE: The term "life-threatening" in the definition of "serious " refers to an event in which the patient was at risk of death at the time of the event; it does not refer to an event which hypothetically might have caused death if it were more severe.”

\section{H I S T O R Y}

Protocol first published: Issue 1, 2008

Review first published: Issue 2, 2009 


\section{CONTRIBUTIONSOFAUTHORS}

CJC: Conception of the idea and co-writing of protocol with MJC.

TL: Co-writing of the protocol, trial selection, data extraction and co-writing the review.

RJ: Trial selection, data extraction and co-writing the review.

\section{DECLARATIONS OF INTEREST}

None known for CJC, TL. RJ has received on one occasion honorarium and travel support from Glaxo Smtih Kline for lecture related to the topic of this review and is a deputy editor of a medical journal financed partially by drug advertising, including medications for asthma.

\section{SOURCES OF SUPPORT}

\section{Internal sources}

- NHS R\&D, UK.

\section{External sources}

- No sources of support supplied

\section{DIFFERENCES BETWEEN PROTOCOLANDREVIEW}

Peto OR was used for primary meta-analysis of Odds Ratios, as otherwise the results are largely dependent on the zero correction adopted. Single inhaler therapy and adjustable maintenance dosing were not included in the review, nor was comparison to higher dose ICS. This was because we decided to restrict our attention to the question of regular formoterol used in addition to the same ICS regimen in both active and control arms. Subgroup analysis was not attempted on the basis of asthma severity or dose of ICS.

\section{NDEX TERMS}

\section{Medical Subject Headings (MeSH)}

Administration, Inhalation; Adolescent; Adrenal Cortex Hormones [*adverse effects; therapeutic use]; Adrenergic beta-Agonists [administration \& dosage; *adverse effects]; Anti-Asthmatic Agents [administration \& dosage; *adverse effects]; Asthma [drug therapy; ${ }^{*}$ mortality]; Ethanolamines [administration \& dosage; *adverse effects]; Randomized Controlled Trials as Topic

\section{MeSH check words}

Adult; Child; Humans 